\title{
WATERBIRD USE AND FOOD AVAILABILITY ON WETLAND RESERVE PROGRAM EASEMENTS ENROLLED IN THE MIGRATORY BIRD HABITAT INITIATIVE
}

A Thesis
Presented to
the Faculty of the Graduate School
at the University of Missouri-Columbia
In Partial Fulfillment
of the Requirements for the Degree
Master of Science
JESSICA LYNN TAPP
Dr. Lisa Webb, Thesis Supervisor

December 2013 
The undersigned, appointed by the dean of the Graduate School, have examined the thesis entitled

\section{WATERBIRD USE AND FOOD AVAILABILITY ON WETLAND RESERVE PROGRAM EASEMENTS ENROLLED IN THE MIGRATORY BIRD HABITAT INITIATIVE}

presented by Jessica L. Tapp, a candidate for the degree of Master of Science, and hereby certify that, in their opinion, it is worthy of acceptance.

Elisabeth B. Webb, Ph.D.

University of Missouri

Thesis Advisor

Joshua Millspaugh, Ph.D.
University of Missouri
Committee Member

Hong S. He, Ph.D.

University of Missouri

Committee Member

Kevin Dacey

Missouri Natural Resource Conservation Service

Committee Member 


\section{ACKNOWLEDGEMENTS}

I would like to thank Dr. Lisa Webb for providing me with this opportunity. Dr. Webb's support, guidance, and assistance were fundamental to this project, and her contributions to my professional development are greatly appreciated. I am also very grateful to the other members of my committee, Dr. Josh Millspaugh, Dr. Hong He, and Mr. Kevin Dacey. Each has contributed substantially by providing thoughtful advice throughout my time at the University of Missouri. In addition, much of the Fisheries and Wildlife faculty along with my fellow grad students have been incredibly supportive and helped make this a positive learning experience.

I would like to thank the Natural Resource Conservation Service (NRCS) Mississippi State University for providing funding for this project. I also would like to thank the Missouri Cooperative Fish and Wildlife Research Unit and the E. K. Love Fellowship for providing financial support for my graduate stipend. I am especially grateful to Keith Cordell (MDC), Brad Pendley (USFWS), and Richard Crossett (USFWS) for their valuable insight and ensuring my technicians and I had a decent place to stay. I am also appreciative of the following individuals for sharing their expertise and assistance with field housing before the move from Arkansas: John Pitre (NRCS), Kevin Nelms (NRCS), Trae Banks, Jerry Ward, and Fred Lucas.

I want to thank the following people for providing significant contributions by assisting with field and lab work: Carl Harris, Andy Dinges, Bryan Cobban, Jason Bleich, Scott James, Jacob Cowan, Jonathan Fox, Kim Cole, Zak Haverly, Dana Brown, and Katie Moreau. These individuals invested many hours into this project, and their hard work and positive attitudes are greatly appreciated. I have to thank Lyn Snoddy, 
specifically, for her moral support and for getting this big ol' ball rolling in a short period of time. I am also indebted to the landowners for their participation. Their enthusiasm for conservation has changed the way I view private land management. These guys often went out of their way to make sure we gained access to their properties.

Lastly, I want to thank my family (relatives and adopted) for their unwavering love, support, and encouragement. I am blessed beyond measure and wouldn't have made it this far without them. 


\section{TABLE OF CONTENTS}

ACKNOWLEDGEMENTS.................................................................................

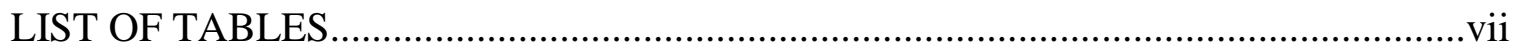

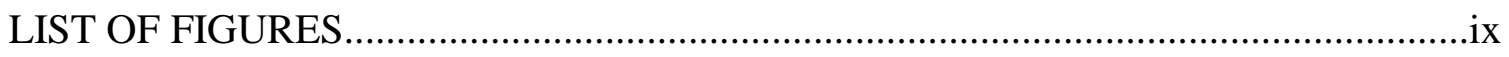

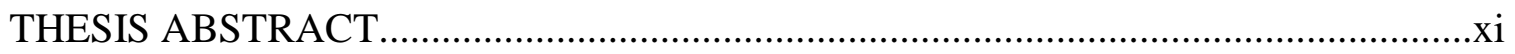

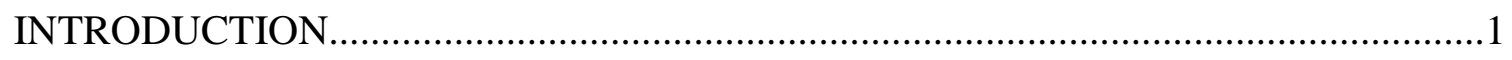

Literature Cited.....................................................................................

CHAPTER I: LOCAL FACTORS AFFECTING SHOREBIRD AND DABBLING DUCK USE ON WETLAND RESERVE PROGRAM EASEMENTS IN THE LOWER MISSISSIPPI ALLUVIAL VALLEY ................................................................13

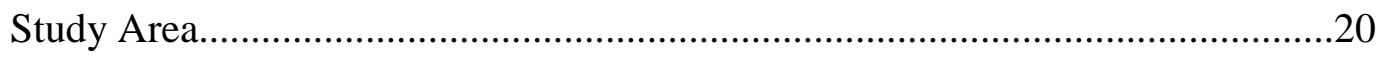

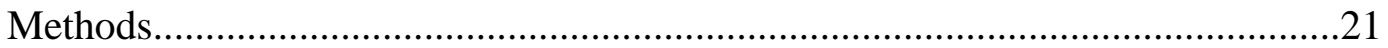

Waterbird Surveys.................................................................21

Habitat Sampling ...................................................................22

Aquatic Invertebrate Sampling.....................................................23

Moist-soil seed sampling...............................................................25

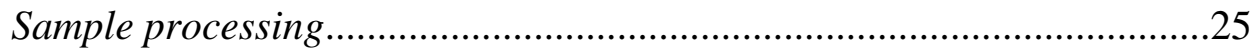

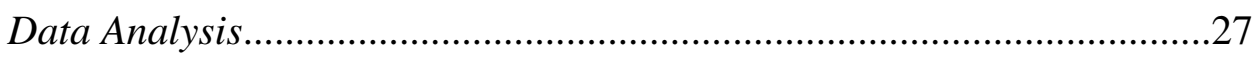

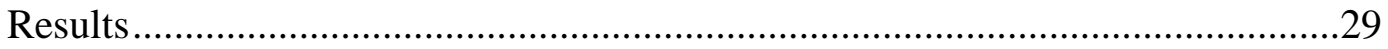

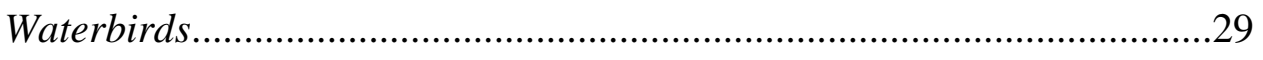

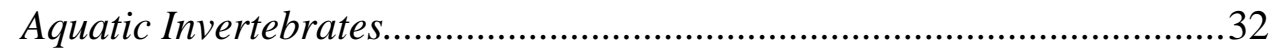

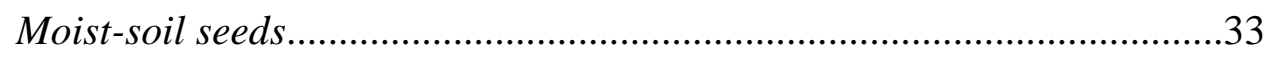

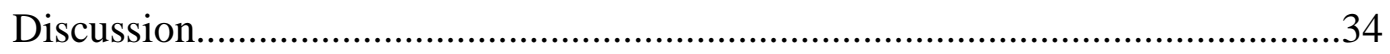

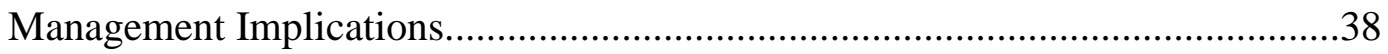


Literature Cited.

CHAPTER II: EFFECTS OF MANAGEMENT ON AQUATIC INVERTEBRATE BIOMASS, PRODUCTION, AND COMMUNITY COMPOSITION AT WETLAND RESERVE PROGRAM EASEMENTS IN THE LOWER MISSISSIPPI ALLUVIAL VALLEY

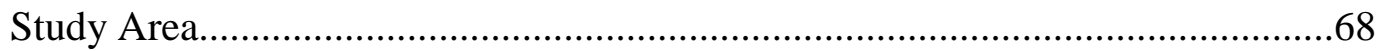

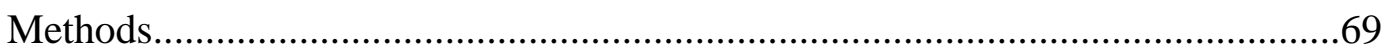

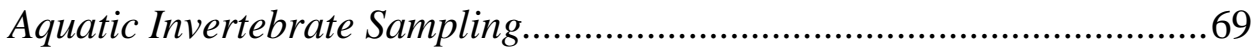

Sample processing ...................................................................... 71

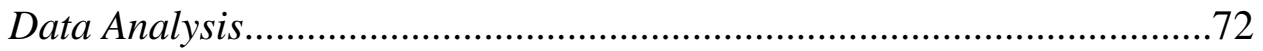

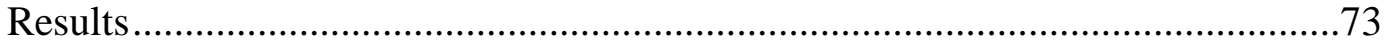

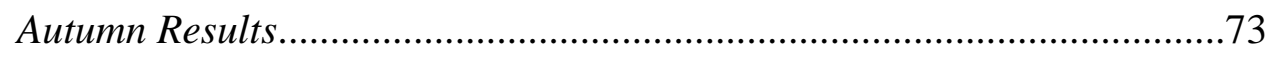

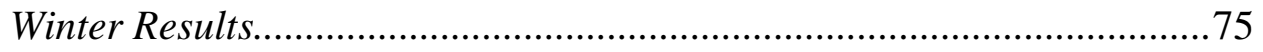

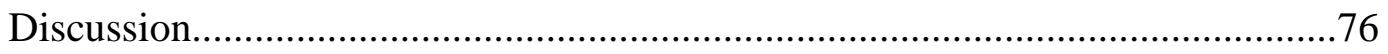

Management Implications....................................................................... 80

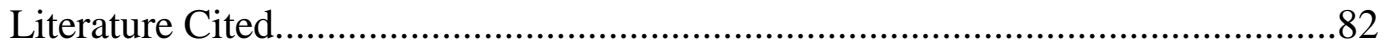

CHAPTER III: THE INFLUENCE OF LANDSCAPE AND LOCAL HABITAT CONDITIONS ON MIGRATORY WATERBIRD USE OF SEASONAL WETLANDS IN THE LOWER MISSISSIPPI ALLUVIAL

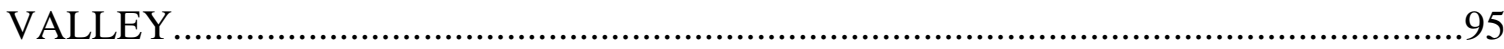

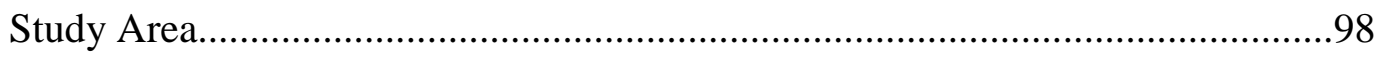

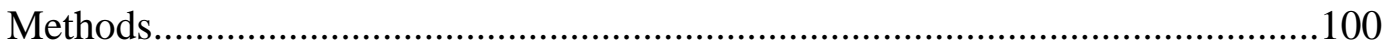

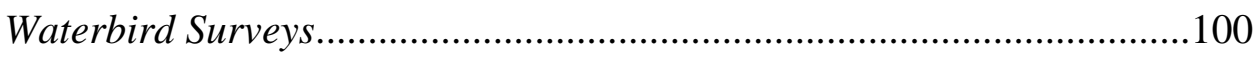

Habitat Sampling .................................................................... 101

Aquatic Invertebrate Sampling....................................................... 102

Moist-soil seed sampling ................................................................103

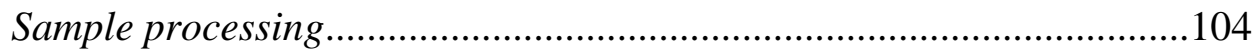


Model selection and data analysis.........................................................107

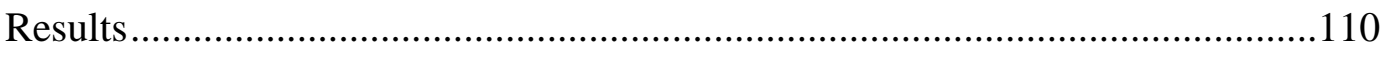

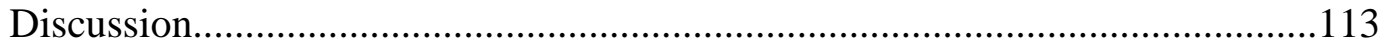

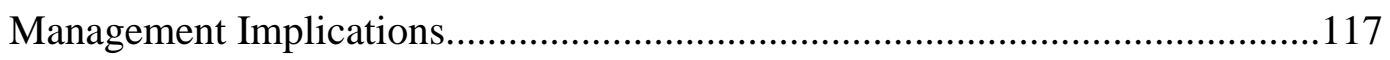

Literature Cited.....................................................................................120

\section{CHAPTER IV: EXECUTIVE}

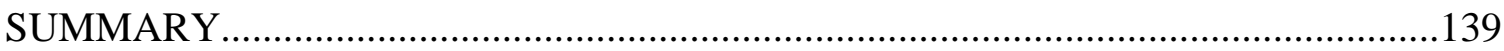

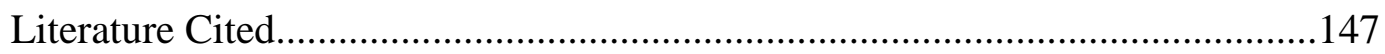

\section{APPENDIX}

A. Mean density (birds/ha) and frequency of occurrence (proportion of surveys in which that species was observed) of each waterbird species observed during autumn surveys at Wetland Reserve Program (WRP) wetlands, Migratory Bird Habitat Initiative (MBHI) wetlands, and publicly owned (PUBLIC) wetlands in the Lower Mississippi Alluvial Valley of Arkansas and Missouri, 3 August -16 September 2011.

B. Mean density (birds/ha) and frequency of occurrence (proportion of surveys in which that species was observed) of waterfowl (Anseriformes) species observed during winter surveys at Wetland Reserve Program (WRP) wetlands, Migratory Bird Habitat Initiative (MBHI) wetlands, and publicly owned (PUBLIC) wetlands in the Lower Mississippi Alluvial Valley of Arkansas and Missouri, 3 November 2011-24 February 2012

C. Mean dry mass $(\mathrm{kg} / \mathrm{ha})$ of all invertebrate taxa observed in samples collected at Migratory Bird Habitat Initiative wetlands $(n=6)$, Wetland Reserve Program wetlands $(n=6)$, and publicly owned wetlands $(n=7)$ in Arkansas and Missouri during autumn 2011 and winter 2012. 


\section{LIST OF TABLES}

Table 1.1. Recent (1-2 years) management histories of Wetland Reserve Program (WRP) sites in Arkansas and Missouri, a subset of which was enrolled in the Migratory Bird Habitat Initiative (MBHI) during summer 2010, which provided additional technical and financial support to landowners to implement moist-soil management practices on their easements.

Table 1.2. Mean $(\overline{\boldsymbol{x}} \pm \mathrm{SE})$ waterbird densities (birds/ha) and species richness (species/ha) at Migratory Bird Habitat Initiative (MBHI) wetlands ( $\mathrm{n}=12$ wetlands), Wetland Reserve Program (WRP) wetlands ( $\mathrm{n}=12$ wetlands), and publicly owned wetlands ( $\mathrm{n}=6$ wetlands) wetlands in Arkansas and Missouri during autumn 2011

Table 1.3. Mean $(\overline{\boldsymbol{x}} \pm \mathrm{SE}$ ) waterfowl densities (birds/ha) and species richness (species/ha) at Migratory Bird Habitat Initiative (MBHI) wetlands ( $\mathrm{n}=13$ wetlands), Wetland Reserve Program (WRP) wetlands ( $\mathrm{n}=12$ wetlands), and publicly owned wetlands ( $\mathrm{n}=7$ wetlands) wetlands in Arkansas and Missouri during autumn 2011

Table 2.1. Mean $(\overline{\boldsymbol{x}} \pm \mathrm{SE})$ aquatic invertebrate biomass ( $\mathrm{kg} / \mathrm{ha})$, familial richness (families/ha), and secondary production $\left(\mathrm{kg} / \mathrm{ha}^{*}\right.$ season) and comparisons $\mathrm{s}^{\mathrm{a}}$ of sampling technique at private wetlands (Wetland Reserve Program and Migratory Bird Habitat Initiative; $n=12$ ) in Arkansas and Missouri during autumn 2011

Table 2.2. Mean $(\overline{\boldsymbol{x}} \pm \mathrm{SE})$ aquatic invertebrate biomass ( $\mathrm{kg} / \mathrm{ha})$, familial richness (families/ha), secondary production ( $\mathrm{kg} / \mathrm{ha}$ *season), and Ephemeroptera, Trichoptera, and Plecoptera (ETP) richness (families/ha) and comparisons ${ }^{\mathrm{a}}$ among Migratory Bird Habitat Initiative (MBHI) wetlands $(n=6)$, Wetland Reserve Program (WRP) wetlands ( $n=6$ ), and publicly owned wetlands $(n=7)$ wetlands in Arkansas and Missouri during autumn 2011 and winter 2011-2012.

Table 2.3. Mean $(\overline{\boldsymbol{x}} \pm \mathrm{SE})$ aquatic invertebrate biomass ( $\mathrm{kg} / \mathrm{ha})$, familial richness (families/ha), and secondary production ( $\mathrm{kg} / \mathrm{ha}$ *season) by individual management activities at private wetlands (Wetland Reserve Program and Migratory Bird Habitat Initiative; $n=12$ ) in Arkansas and Missouri during autumn 2011 and winter 2011-2012.

Table 3.1. Local (within study wetlands) and landscape variables that were used to construct models that describe the use of seasonal wetlands by autumn migrating shorebirds ( $n=9$ wetlands) and wintering dabbling ducks ( $n=18$ wetlands) within the Mississippi valley of Arkansas and Missouri, August-September 2011 and November 2011-February 2012.

Table 3.2. Local (within study wetlands), landscape and combined models created to describe the use of seasonal wetlands ( $n=9$ wetlands) by autumn migrating 
shorebirds within the Mississippi valley of Arkansas and Missouri, AugustSeptember 2011 .

Table 3.3. Local (within study wetlands) and landscape $(3.5 \mathrm{~km}$ and $10 \mathrm{~km}$ radius) predictor variables that were used to construct models that describe the use of seasonal wetlands ( $n=18$ wetlands) by wintering dabbling ducks within the Mississippi valley of Arkansas and Missouri, November 2011-February 2012

Table 3.4. Mean $( \pm S E)$ local and landscape predictors and waterbird responses among seasonal wetlands during autumn (August-September 2011; $n=9$ ) and winter (November 2011-February 2012; $n=18$ ) in the Mississippi valley of Arkansas and Missouri.....

Table 3.5. Results of best fit general linear mixed model regressions with model parameter estimates, number of parameters $(K)$, Akaike's Information Criterion $\left(\mathrm{AIC}_{c}\right), \Delta \mathrm{AIC}_{c}$, and $\mathrm{AIC}_{c}$ weights $\left(w_{i}\right)$ used to rank models containing factors hypothesized to predict total shorebird abundance and species richness at seasonal wetlands ( $n=9$ wetlands) in the Mississippi valley of Arkansas and Missouri, August-September 2011. Models with lower $\mathrm{AIC}_{c}$ and $\Delta \mathrm{AIC}_{c}$ had more substantial support. Adjusted $R^{2}$ values are reported for comparison.

Table 3.6. Results of best fit general linear mixed model regressions with model parameter estimates, number of parameters $(K)$, Akaike's Information Criterion $\left(\mathrm{AIC}_{\mathrm{c}}\right), \Delta \mathrm{AIC}_{\mathrm{c}}$, and $\mathrm{AIC}_{\mathrm{c}}$ weights $\left(w_{i}\right)$ used to rank models containing factors hypothesized to predict total dabbling duck abundance and species richness at seasonal wetlands ( $n=18$ wetlands) in the Mississippi valley of Arkansas and Missouri, November 2011-February 2012. Models with lower $\mathrm{AIC}_{\mathrm{c}}$ and $\Delta \mathrm{AIC}_{\mathrm{c}}$ had more substantial support. Adjusted $R^{2}$ values are reported for comparison. 


\section{LIST OF FIGURES}

Figure 1.1. Locations of Arkansas and Missouri study wetlands within Wetland Reserve Program (WRP) easements, WRP wetlands enrolled in the Migratory Bird Habitat Initiative (MBHI), and public managed wetlands used to assess effects of moistsoil management on migratory waterbird use and food availability during autumn 2011 and winter 2011-2012.

Figure 1.2. Examples illustrating autumn 2011 shorebird habitat sample transects and designated water depth strata within a wetland.

Figure 1.3. Relationship between autumn bi-weekly shorebird densities and observed vegetation cover at Wetland Reserve Program, Migratory Bird Habitat Initiative, and Public wetlands $(\mathrm{n}=29)$ in Arkansas and Missouri during autumn 2011

Figure 1.4. Relationship between autumn bi-weekly shorebird densities and observed vegetation height at Wetland Reserve Program, Migratory Bird Habitat Initiative, and Public wetlands $(\mathrm{n}=29)$ in Arkansas and Missouri during autumn 2011 .56

Figure 1.5. Mean dabbling duck densities observed at all private wetlands (Wetland Reserve Program and Migratory Bird Habitat Initiative) in Arkansas and Missouri with active and passive inundation strategies from October 2012 - February 2012 .

Figure 1.6. Mean dabbling duck densities at private wetlands (Wetland Reserve Program and Migratory Bird Habitat Initiative) displayed by wetland management practices and other site characteristics in Arkansas and Missouri during winter 2011-2012. For mow/disk, plant, inundation and hunt categories, "yes" indicates that the activity occurred at the wetland in 2011. Site age is a wetland variable for which "yes" indicates initial enrollment in WRP and restoration occurred 0-10 years previously, and "no" indicates restoration and enrollment 10-20 years previously...

Figure 1.7. Relationship between bi-weekly dabbling duck densities and observed vegetation cover at Wetland Reserve Program, Migratory Bird Habitat Initiative, and Public wetlands $(\mathrm{n}=33)$ in Arkansas and Missouri during winter 20112012

Figure 1.8. Initial seed biomass at private wetlands (Wetland Reserve Program and Migratory Bird Habitat Initiative) displayed by wetland management practices in Arkansas and Missouri during October 2011. For mow/disk, plant, and inundation categories, "yes" indicates that the activity occurred at the wetland in 2011 
Figure 1.9. Relationship between initial seed biomass and total seed depletion at Wetland Reserve Program, Migratory Bird Habitat Initiative, and Public wetlands $(n=29)$ in Arkansas and Missouri during winter 2011-2012.

Figure 2.1. Secondary production estimates in benthic core and nektonic sweep samples collected at Migratory Bird Habitat Initiative (MBHI) wetlands $(n=6)$ and Wetland Reserve Program (WRP) wetlands $(n=6)$, in Arkansas and Missouri during autumn 2011

Figure 2.2. Seasonal invertebrate production biweekly sweep samples $(n=601)$ collected at Migratory Bird Habitat Initiative (MBHI) sites $(n=6)$, Wetland Reserve Program (WRP) sites $(n=6)$, and publicly owned wetlands $(n=7)$ in Arkansas and Missouri during autumn 2011 and winter 11-12. Public wetlands in autumn were dry, with one exception, and were omitted from autumn analyses

Figure 2.3. Bi-weekly secondary invertebrate production in sweep samples collected at Migratory Bird Habitat Initiative (MBHI) wetlands $(n=6)$, Wetland Reserve Program (WRP) wetlands $(n=6)$, and publicly owned wetlands $(n=7)$ in Arkansas and Missouri during winter 2011-2012.

Figure 3.1. Model averaged parameter estimates and associated 95\% confidence intervals for the parameters included in best approximating models according to Akaike's Information Criterion $\left(\mathrm{AIC}_{\mathrm{c}}\right)$ and $\triangle \mathrm{AIC}_{\mathrm{c}}$ that examined $(\mathrm{A})$ shorebird abundance and (B) shorebird species richness at seasonal wetlands ( $n=9$ wetlands) in the Mississippi valley of Arkansas and Missouri, August-September 2011. Parameter acronyms are described in Table 3.1

Figure 3.2. Model averaged parameter estimates and associated 95\% confidence intervals for the parameters included in best approximating models according to Akaike's Information Criterion $\left(\mathrm{AIC}_{\mathrm{c}}\right.$ ) and $\triangle \mathrm{AIC}_{\mathrm{c}}$ that examined (a) dabbling duck abundance and (b) dabbling duck species richness at seasonal wetlands ( $n=18$ wetlands) in the Mississippi valley of Arkansas and Missouri, November 2011-February 2012. Parameter acronyms are described in Table 3.2 


\section{THESIS ABSTRACT}

The Natural Resource Conservation Service implemented the Migratory Bird Habitat Initiative (MBHI) in summer 2010 to mitigate potential loss of wetland habitat caused by the Deepwater Horizon oil spill. The goal of the MBHI was to improve wetland habitats on private farmlands, catfish ponds, and Wetland Reserve Program (WRP) easements in the Lower Mississippi Alluvial Valley (LMAV) to provide additional habitats for wintering and migrating waterbirds. Improving habitat on WRP easements is particularly important, given that landowners are not required to provide additional management after initial enrollment and restoration. Priorities for WRP wetlands enrolled in the MBHI included addressing waterbird food habitats, providing habitat structure, and additional management activities such as planting and/or disking on seasonal wetlands. Although WRP sites have been designated as critical wildlife habitat, little research has been conducted to evaluate management on WRP easements or quantify the effects on wildlife use and wetland habitats in the LMAV. My main objectives were to evaluate factors influencing waterbird density and species richness by making relative comparisons between MBHI wetlands and reference wetlands with differing management activities, food biomass, and surrounding landscapes.

I conducted bi-weekly waterbird surveys and collected seed and invertebrate samples on randomly selected conservation easement lands enrolled in the MBHI $(n=13)$, traditional WRP sites ( $n=12)$, and intensively managed publicly owned wetlands $(n=7)$ in the LMAV of Arkansas and Missouri to quantify food availability and habitat use from August-September 2011 and November 2011-February 2012 by fall migrating shorebirds 
(Charadriiformes) and wintering dabbling ducks (Anatinae). Additionally, I quantified habitat surrounding each study wetland in terms of proximity to, percent area and interspersion of WRP easements within different spatial scales, based the distance shorebirds $(1.5 \mathrm{~km})$ and dabbling ducks $(3.5 \mathrm{~km}, 10 \mathrm{~km})$ fly between wetlands within stopover or wintering areas.

Shorebird densities were influenced by vegetative conditions, with greater densities at sites with lower percent cover and shorter vegetation height, and most shorebirds used wetlands with mean vegetation height $<30 \mathrm{~cm}$. Dabbling duck densities at MBHI wetlands were 2.1 times greater than at WRP wetlands, but did not differ from densities at public wetlands. Regardless of wetland type, dabbling duck densities were approximately 2.6 times greater at private wetlands (MBHI and WRP) that were actively inundated compared to sites that were not inundated. Additionally, wetlands that were planted with moist-soil seeds had dabbling duck densities 1.8 times greater than sites where moist-soil seeds were not planted. Dabbling duck densities were also influenced by percent vegetative cover, with the greatest densities occurring at sites with approximately $50 \%$ cover. Dabbling duck densities were 1.8 times greater at wetlands with hunting activities, compared to sites with no hunting activity. Inability to survey all sites at times when waterbirds were most likely to be present may have confounded my ability to detect a relationship between food availability and waterbird use metrics.

During autumn, invertebrate biomass estimates from soil core samples were over 4 times greater than sweep samples. Conversely, sweep sample familial richness was $50 \%$ greater than core sample estimates. Sweep production estimates were also $60 \%$ greater than benthic core production estimates, regardless of wetland type. Wetland 
invertebrate studies should consider objectives carefully when determining sampling methods. Failure to sample both nektonic and benthic invertebrates in seasonal wetlands may cause studies to underestimate common aquatic invertebrate metrics. Although invertebrate biomass was not affected by mowing, active inundation, and site age, invertebrate production at wetlands that were mowed was approximately 4 times greater compared to wetlands that were not mowed. Mowing of vegetation can increase detritus in seasonal wetlands and may be an important tool for providing food for invertebrates. During winter, invertebrate production at WRP wetlands and MBHI wetlands was greater than production at public wetlands. However, invertebrate production did not differ between WRP and MBHI wetlands. Drought conditions on private lands may have increased decomposition and productivity of aquatic plants, also increasing detritus for invertebrates during winter. I also tested for an effect of sampling frequency on invertebrate biomass during winter and found no difference between monthly and biweekly sampling, indicating that sampling frequency may be reduced if secondary production is not a variable of interest.

Management activities at each site did not adequately explain variation in waterbird densities; therefore I created a set of a priori models to test the hypothesis that a combination of landscape and local variables would explain a greater amount of variability in bird use metrics than landscape or local predictors individually. The best approximating models for both shorebird abundance and species richness contained only wetland area (null models) and accounted for $39 \%$ and $41 \%$ of the model weights, respectively. Shorebirds species have distinct foraging strategies and habitat requirements, and including all species in a single model may have obscured some habitat 
variables in predicting shorebird use. Juxtaposition of WRP within $1.5 \mathrm{~km}$ of study sites was another top variable in competing shorebird models and accounted for $34 \%$ of the model weights for abundance and $29 \%$ for species richness. Landscapes with lower juxtaposition (i.e. large continuous tracts of WRP wetlands) were likely more successful at retaining water and shorebird habitat, thus attracting more shorebirds.

Local food abundance, including invertebrate biomass, seed biomass and seed depletion, as well as percent vegetative cover, and cropland juxtaposition within $10 \mathrm{~km}$ were all components in the dabbling duck abundance model that accounted for $62 \%$ of the model weights. Dabbling ducks used seasonal wetlands that contained abundant local wetland foods (at least moist-soil seeds) that had several agricultural fields nearby, indicating a reliance on natural and anthropogenic food sources. However, invertebrate biomass may be a poor predictor of habitat use by all dabbling ducks due to inter- and intra-specific variation in the relative importance of invertebrates as a dietary component during winter. There were ten models that were best fit as predictors of dabbling duck species richness, including the null model. These models contained the variables percent cover, cropland area within 10km, WRP area within $10 \mathrm{~km}$, and cropland juxtaposition within $10 \mathrm{~km}$. The associations between these variables and dabbling duck species richness were primarily negative, providing counterintuitive and confounding results and may be a consequence of species-specific dabbling duck responses to broad-scale habitat patterns.

Conservation of wetland complexes may be paramount to ensuring adequate stopover and wintering resources are consistently present within landscapes that are continuously being altered through anthropogenic activities. Semi-permanent wetlands, 
which can remain inundated for a few years at a time, and other persistent aquatic habitats likely provide an important alternative to seasonal wetlands for shorebirds in times with limited wetland availability. In agriculturally dominated landscapes such as the LMAV, conservation programs that promote winter flooding of croplands adjacent to important wetland habitats may be an efficient method of providing additional habitats for dabbling ducks. Wetland management at broader spatial scales will likely require private landowner support and a fundamental understanding of how individual wetlands are incorporated into complexes to provide sufficient habitat for migratory waterbirds. 


\section{INTRODUCTION}

Waterbirds include some of the most migratory animals in the world, often travelling more than $12,000 \mathrm{~km}$ between their wintering and breeding grounds (Helmers 1992, Harrington et al. 2002). Many waterbird species breed in the Arctic, migrate through North America, and winter from the southern U.S. to South and Central America. Waterbirds rely on stopover and wintering habitats for food and rest to meet the energetic requirements of migration (Skagan and Knopf 1993) and lack of these habitats may be detrimental to their survival or breeding success (Helmers 1992, Davis and Smith 1998a). Limited food availability can increase the time spent meeting the nutritional demands of migration (Newton 2006), while survival, nest initiation, and breeding success can potentially be affected by limited and low quality food availability at stopover sites, thereby creating a nutritional bottleneck (Heitmeyer and Fredrickson 1981, Delnicki and

Reinecke 1986, Raveling and Heitmeyer 1989, Anteau and Afton 2004, Drent et al. 2006).

Record low waterfowl populations in the mid-1980's motivated a collective effort between the United States and Canada to develop a framework for collaborative waterfowl habitat conservation across North America (King et al. 2006). The North American Waterfowl Management Plan (NAWMP) was enacted in 1986 with the goal of restoring waterfowl (Anseriformes) populations to levels observed in the 1970s (NAWMP 1986, Williams et al. 1999). The most recent NAWMP revision reported remarkably successful habitat conservation efforts, contributing to rebounding waterfowl population levels, but that declining U.S. waterfowl hunter participation highlighted the 
need to strengthen support for wetland conservation (NAWMP 2012). Furthermore, sixteen of the 29 federally endangered and threatened bird species in the Lower 48 states are primarily wetland inhabitants (Harrington 2003), emphasizing the importance of identifying factors limiting waterbird populations, and evaluating current habitat management practices. While the factors that affect waterbird populations are not fully understood, results from several studies suggest nonbreeding habitat availability and quality can impact waterbird population levels (Heitmeyer and Fredrickson 1981, Kaminski and Gluesing 1987, Heitmeyer and Raveling 1989, Harrington 2003).

One of the primary areas containing habitat for nonbreeding waterbirds in the U.S. is located in the Lower Mississippi Alluvial Valley (LMAV). The LMAV includes the historic 10 million ha floodplain of the Mississippi River (King et al. 2006) and stretches across 7 states from southern Illinois south to the Gulf Coast of Louisiana (Figure 1.1). Glacial advances and retreats during the Quaternary Period further alluviated the region to its current condition (King et al. 2006). The highly variable soils contain mineral deposits that were carried by glacial outwashes from as far as the Rocky and Appalachian Mountains and the upper Midwest (Gardiner and Oliver 2005, Klimas et al 2009). Sands, silts, and clays are all located within the floodplain, depending on the distance to channels and historic flood frequency (Gardiner and Oliver 2005). Annual flooding was traditionally driven by winter and spring precipitation and created favorable habitat conditions for the life-cycles of aquatic invertebrates and germination of moistsoil seeds, thereby providing food for migrating and wintering waterbirds (Heitmeyer and Fredrickson 1981). While the frequency and duration of historic flooding events varied, a large portion of the LMAV was likely inundated every winter (Heitmeyer and 
Fredrickson 1981). Wide-scale anthropogenic modification altered the natural flooding regimes of the Mississippi River and its' confluents to the extent that much of the LMAV no longer functions as an active floodplain ecosystem (Smith and Winkley 1996, Gardiner and Oliver 2005). Flood control and the resulting ecological isolation of Mississippi River floodplain habitats allowed for conversion of most of the bottomland forests to agricultural land use, aquaculture facilities, and urban development (Elliott and McKnight 2000). Currently, widespread flooding from abundant rain (Reinecke et al. 1989), backwater flooding associated with river-transported snow melt, and irrigation of agricultural crops typically ensures the presence of shallow water foraging sites in the LMAV throughout spring (Twedt et al. 1998). However, flooded wetland habitat is generally scarce during autumn migration due to reduced precipitation and high evapotranspiration (Reinecke et al. 1989, Twedt 2013). In response to the natural hydrologic variability of wetlands, waterbirds have adapted to be highly mobile and use wetlands opportunistically, often within a few hours of a site becoming inundated (Belrose and Crompton 1970, Fredrickson and Heitmeyer 1988, Skagen and Knopf 1993). The opportunistic habitat use and flexible foraging behaviors of most waterbirds is especially important in the perpetually changing agricultural system within the LMAV (Davis and Smith 1998, Skagen et al. 2008).

Prior to major levee development and channelization in the LMAV, waterbird use was limited to wetlands formed by the natural processes of the ever-changing river system (King et al. 2006). The LMAV lost over 70 percent of the historic bottomland hardwood wetlands through conversion to agriculture, tree harvest, levee development, and channelization of the Mississippi River and its tributaries (Fredrickson 2005, King et 
al. 2005, King et al. 2006). Sloughs, swales, oxbows, and other limited features within the bottomland hardwood matrix that once provided suitable habitat for interior-migrating shorebirds were essentially eliminated, leaving unvegetated agricultural lands and other low quality sites as alternative habitat (Galloway 1980, Forsythe 1985, Reinecke et al. 1989). Accordingly, shorebird (Charadriiformes) populations in North America have been declining, and the number of interior-migrating shorebirds has decreased at much greater rates than coastal migrants (Morrison et al. 2000, Thomas et al. 2006). In response to drastically reduced wetland habitat availability in the LMAV, the Lower Mississippi Valley Joint Venture (LMVJV) established the goal of providing wintering habitat for 8.7 million ducks and 1.4 million geese annually (Loesch et al. 1994). In addition, biologists considered migration patterns and continental population estimates to predict use by an estimated 0.5 million shorebirds, which the LMVJV designated as a tentative population goal for shorebird management within the LMAV (Loesch et al. 2000, King et al. 2006). The most recent approximation of shorebirds migrating through the region was by Lehnen (2010), who used surveys from both public and private lands to conservatively estimate a total of 285,367 shorebirds using the region during autumn migration. The lack of regional surveys for non-waterfowl taxa before and after human interference has left biologists with little more than speculation as to how drastic landscape modifications have affected populations of migrating shorebirds. Further monitoring of waterbirds on public and private wetland habitats will likely result in more precise population estimates and habitat management goals.

Comprehensive reforestation and wetland restoration efforts were initiated in the 1990s by the U.S. government, with a particular emphasis on private lands (King et al. 
2006). Restoration of private lands was an important decision, considering approximately $70 \%$ of the land in the Lower 48 states is privately owned (Gray and Teels 2006). The Wetland Reserve Program (WRP) is a voluntary easement program established by the 1990 Farm Bill and administered by the Natural Resources Conservation Service (NRCS) to restore, enhance and protect wetlands on private properties. Through financial incentives and technical support, private landowners are encouraged to protect and enhance existing wetlands, as well as retire farmlands from agricultural production and restore them to their previous hydrology (NRCS 2013a). As of 2013, over 930,000 hectares have been enrolled in the WRP with approximately $20 \%$ of the enrollments located in the LMAV (NRCS 2013a). Though many private wetlands enrolled in conservation easement programs are managed specifically for waterfowl habitat during winter, these easements can also provide migration stopover sites for other waterbirds during the spring and early autumn when managed as moist-soil wetlands (Twedt et al. 1998). Moist-soil wetlands, characterized as seasonally flooded wetlands that support early successional hydrophytic plants, are an important habitat for waterbirds throughout the winter and during spring and autumn migrations (Fredrickson and Taylor 1982, Helmers 1992, Nelms et al. 2007, Kross et al. 2008).

Very little research has been conducted within the LMAV region to evaluate the importance of WRP easements to waterbirds during migration. One way to evaluate the relative success of wetland restoration efforts is to consider the abundance and diversity of waterbirds WRP easements support relative to other wetland types. Another method for assessing habitat quality of restored wetlands is to estimate food biomass and the potential waterfowl carrying capacity of these sites (Brasher 2006, Evans-Peters et al. 
2012, Olmstead et al. 2013). Waterfowl managers rely on precise seed biomass estimates to estimate the number of ducks that can be energetically supported at a wetland for a period of time (Haukos and Smith 1993, Anderson and Smith 1998). Many waterbirds also depend on invertebrates, which are the major source of dietary protein necessary for waterbird survival and reproduction (Krapu and Reinecke 1992, Skagen and Oman 1996, Davis and Smith 1998a, Davis and Bidwell 2008). Research indicates shorebirds feed almost exclusively on invertebrates (Skagen and Oman 1996), so studies of invertebrate production and turnover rates can be beneficial to wetland managers by providing them with means to assess wetland carrying capacity for nongame waterbirds.

One of the most recent challenges to waterbird habitats in the LMAV was the Deepwater Horizon oil spill that occurred in the Gulf of Mexico in 2010 (Henkel et al. 2012, Mendelssohn et al. 2012, Buler et al. 2013). To mitigate potential wetland habitat alteration and destruction from oil pollution, NRCS implemented the Migratory Bird Habitat Initiative (MBHI) in summer 2010. The goal of the MBHI was to improve habitats on private farmlands, catfish ponds, and WRP easements in states near the Gulf of Mexico to provide additional habitats for wintering and migrating waterbirds that may have been displaced from impacted coastal wetlands. After initial wetland restoration, WRP participants have no contractual obligation to provide additional management for wildlife on the wetland (NRCS 2013a). Through MBHI, landowners were provided monetary support to actively manage WRP easements. Specific objectives for WRP easements include addressing food habitat needs for waterbird species likely impacted by the oil spill, providing habitat structure, and additional management such as planting and/or disking on seasonal wetlands (NRCS 2013b). 
Thorough evaluation of WRP wetlands is essential, not only to better understand the effects of management and environmental factors on use by migrating and wintering waterbirds, but also to determine the relative importance of WRP easements to waterbirds as migration stopover and wintering habitat. The overall goal of my research was to evaluate factors influencing waterbird density and species richness by making relative comparisons between WRP easements with differing management activities, surrounding landscape, and food biomass. My thesis includes three major chapters and an inclusive summary evaluating:

1. Local factors affecting shorebird and dabbling duck use on Wetland Reserve Program easements in the Lower Mississippi Alluvial Valley (Chapter I)

2. Effects of management on aquatic invertebrate biomass, production, and community composition at Wetland Reserve Program easements in the Lower Mississippi Alluvial Valley (Chapter II)

3. The effects of landscape factors on waterbird use and invertebrate community composition at Wetland Reserve Program easements in the Lower Mississippi Alluvial Valley (Chapter III)

4. Management implications for Wetland Reserve Program easements in the Lower Mississippi Alluvial Valley (Chapter IV) 


\section{LITERATURE CITED}

Anderson, J. T., and L. M. Smith. 2000. Invertebrate response to moist-soil management of playa wetlands. Ecological Applications 10(2):550-558.

Bellrose, F. C. and R. D. Crompton. 1970. Migrational behavior of mallards and black ducks as determined from banding. Illinois Natural History Survey Bulletin 30: 167-234.

Buler, J. J., M. L. Sieges, and J. A. Smolinsky. 2013. Assessment of Bird Response to the NRCS Migratory Bird Habitat Initiative using Weather Surveillance Radar: Final Report. Department of Entomology and Wildlife Ecology, University of Delaware.

Davis, C. A. and J. R. Bidwell. 2008. Response of aquatic invertebrates to vegetation management and agriculture. Wetlands 28(3):793-805.

Davis, C. A., and L. M. Smith. 1998. Ecology and management of migrant shorebirds in the Playa Lakes Region of Texas. Wildlife Monographs 140:1-45.

Delnicki, D., and K. J. Reinecke. 1986. Mid-winter food use and body weights of mallards and wood ducks in Mississippi. Journal of Wildlife Management 50:4351.

Drent, R.H. 2006. The timing of birds' breeding seasons: the Perrins hypothesis revisited especially for migrants. Ardea 94:305-322.

Elliott, L. and K. McKnight, editors. 2000. U.S. Shorebird Conservation Plan: Lower Mississippi Valley/Western Gulf Coastal Plain. Prepared by Mississippi Alluvial Valley/ West Gulf Coastal Plain Working Group. Revised December 5, 2011.

Fredrickson, L. H. 2005. Contemporary bottomland hardwood systems: structure, function, and hydrologic condition resulting from two centuries of anthropogenic activities. Pages 19-35 in L. H. Fredrickson, S. L. King, and R. M. Kaminski, editors. Ecology and management of bottomland hardwood systems: the state of our understanding. University of Missouri-Columbia, Gaylord Memorial Laboratory Special Publication No. 10, Puxico, USA.

Fredrickson, L. H. 1991. Strategies for water level manipulations in moist-soil systems. U.S. Department of the Interior, Fish and Wildlife Service. Fish and Wildlife Leaflet 13 in D. Cross and P. Vohs, editors. Waterfowl Management Handbook. Fort Collins, Colorado.

Fredrickson, L. H., and M. E. Heitmeyer. 1988. Waterfowl use of forested wetlands of the southern United States: an overview. Pages 307-323 in M. W. Weller, editor. Waterfowl in winter. University of Minnesota Press, Minneapolis, Minnesota, USA. 
Fredrickson, L. H., and S. T. Taylor. 1982. Management of seasonally flooded impoundments for wildlife. U.S. Fish and Wildlife Service, Resource Publication 148, Washington, D.C., USA.

Forsythe, S. W. 1985. The protection of bottomland hardwoods along the Lower Mississippi Valley. Transactions of North American Wildlife and Natural Resource Conference 45:333-340.

Galloway, G. E., Jr. 1980. Ex-post evaluation of regional water resources development: the case of the Yazoo-Mississippi Delta. U. S. Army Engineering Institute Water Resour. Rep. IWR-80-D1. 304 p.

Gardiner, E. and J. Oliver. 2005. Restoration of bottomland hardwood forests in the Lower Mississippi Alluvial Valley, U.S.A. p. 235-51. In J. Stanturf and P. Madsen (eds.) Restoration of boreal and temperate forests. CRC Press, Boca Raton, FL, USA.

Gray, M. J., R. M. Kaminski, G. Weerakkody, B. D. Leopold, and K. C. Jensen. 1999. Aquatic invertebrate and plant responses following mechanical manipulations of moist-soil habitat. Wildlife Society Bulletin 27:770-779.

Gray, R. L. and Teels, B. M.. 2006. Wildlife and fish conservation through the Farm Bill. Wildlife Society Bulletin 34: 906-913.

Harrington, B. A. 2003. Shorebird management during the non-breeding season - an overview of needs, opportunities, and management concepts. Water Study Group Bulletin 100:59-66.

Haukos, D.A. and L.M. Smith. 1993. Moist-soil management of playa lakes for migrating and wintering ducks. Wildlife Society Bulletin 21:288-298.

Heitmeyer, M. E., and L. H. Fredrickson. 1981. Do wetland conditions in the Mississippi Delta hardwoods influence Mallard recruitment? Transactions of the North American Wildlife and Natural Resources Conference 46:44-57.

Helmers, D. L. 1992. Shorebird management manual. Western Hemisphere Shorebird Reserve Network, Manomet, Massachusetts.

Henkel, J. R., B. J. Sigel, and C. M. Taylor. 2012. Large-Scale Impacts of the Deepwater Horizon Oil Spill: Can Local Disturbance Affect Distant Ecosystems through Migratory Shorebirds? BioScience 62:676-685.

Kadlec, J. A. 1962. Effects of a drawdown on a waterfowl impoundment. Ecology 43:267-281.

Kaminski, R. M., and E. A. Gluesing. 1987. Density and habitat-related recruitment in mallards. The Journal of Wildlife Management 51:141-148. 
King, S. L, J. P. Shepard, K. Ouchley, J. A. Neal, and K. Ouchley. 2005. Bottomland hardwood forests: past, present, and future. Pages 1-17 in L. H. Fredrickson, S. L. King, and R. M. Kaminski, editors. Ecology and management of bottomland hardwood systems: the state of our understanding. University of MissouriColumbia, Gaylord Memorial Laboratory Special Publication No. 10, Puxico, USA.

King, S. L., D. J. Twedt, and R. R. Wilson. 2006. The role of the wetland reserve program in conservation efforts in the Mississippi alluvial valley. Wildlife Society Bulletin 34(4):914-920.

Klimas, C., E. Murray, T. Foti, J. Pagan, M. Williamson, and H. Langston. 2009. An ecosystem restoration model for the Mississippi Alluvial Valley based on geomorphology, soils, and hydrology. Wetlands 29:430-450.

Krapu, G. L. and K. J. Reinecke. 1992. Foraging ecology and nutrition. p. 1-29. In B. D. J. Batt, A. D. Afton, M. G. Anderson, C. D. Ankney, D. H. Johnson, J. A. Kadlec, and G. L. Krapu (eds.) Ecology and Management of Breeding Waterfowl. University of Minnesota Press, Minneapolis, MN, USA.

Kross, J., R. M. Kaminski, K. J. Reinecke, E. J. Penny, and A. T. Pearse. 2008. Moistsoil seed abundance in managed wetlands in the Mississippi Alluvial Valley. The Journal of Wildlife Management 72:707-714.

Lehnen, S. E. 2010. Chronology, distribution, and dispersion of autumn migrating shorebirds through the Lower Mississippi River Alluvial Valley. Postdoctoral Research, Arkansas Cooperative Fish and Wildlife Research Unit, University of Arkansas, Fayetteville, AR, USA.

Loesch, C. R., D. J. Twedt, K. Tripp, W. C. Hunter, and M. S. Woodrey. 2000. Development of objectives for waterfowl and shorebirds in the Mississippi alluvial valley. Pages 8-11 in USDA Forest Service Proceedings RMRS-P-16.

Loesch, C. R., K. J. Reinecke, and C. K. Baxter. 1994. Lower Mississippi Valley Joint Venture evaluation plan. North American Waterfowl Management Plan, Vicksburg, Mississippi, USA.

Mendelssohn, I. A., G. L. Andersen, D. M. Baltz, R. H. Caffey, K. R. Carman, J. W. Fleeger, S. B. Joye, Q. Lin, E. Maltby, and E. B. Overton. 2012. Oil impacts on coastal wetlands: implications for the Mississippi River Delta ecosystem after the Deepwater Horizon oil spill. BioScience 62:562-574.

Mitsch, W. J. and J. G. Gosselink. 2007. Wetlands. Fourth Edition. John Wiley and Sons, Inc, Hoboken, New Jersey, USA.

Morrison, R.I.G., R. E. Gill Jr., B. A. Harrington, S. Skagen, and G. W. Page. 2000. Population estimates of Nearctic shorebirds. Waterbirds 23: 337-352. 
Natural Resources Conservation Service. 2013b. Migratory Bird Habitat Initiative. https://prod.nrcs.usda.gov/wps/portal/nrcs/detailfull/national/programs/farmbill/in itiatives/?cid=steldevb1027669/ Accessed 2013 June 27.

Natural Resources Conservation Service. 2013a. Wetlands Reserve Program. http://www.nrcs.usda.gov/wps/portal/nrcs/main/national/programs/easements/wetl ands/ Accessed 2013 June 27.

Nelms, K. D., B. Ballinger, and A. Boyles, editors. 2007. Wetland management for waterfowl handbook. Mississippi River Trust, Natural Resources Conservation Service, Mississippi, USA.

Newton, I. 2006. Can conditions experienced during migration limit the population levels of birds? Journal of Ornithology 147:146-166.

North American Waterfowl Management Plan, Plan Committee. 1986. North American Waterfowl Management Plan: A strategy for conservation. Canadian Wildlife Service, U.S. Fish and Wildlife Service, 19 pp.

North American Waterfowl Management Plan, Plan Committee. 2012. North American Waterfowl Management Plan. People Conserving Waterfowl and Wetlands. Canadian Wildlife Service, U.S. Fish and Wildlife Service, Secretaria de Medio Ambiente y Recursos Naturales, 48 pp.

Ratti, J. T., and E. O. Garton. 1994. Research and experimental design. Pages 1-23 in T. A. Bookhout, editor. Research and management techniques for wildlife and habitats. Fifth edition. The Wildlife Society, Bethesda, Maryland.

Raveling, D. G., and M. E. Heitmeyer. 1989. Relationships of population size and recruitment of pintails to habitat conditions and harvest. Journal of Wildlife Management 53:1088-1103.

Reinecke, K. J., R. M. Kaminski, D. J. Moorhead, J. D. Hodges, and J. R. Nassar. 1989. Mississippi Alluvial Valley, p. 203-247. In: L. M. Smith, R. L. Pederson and R. M. Kaminski (eds.). Habitat management for migrating and wintering waterfowl in North America. Texas Tech Univ. Press, Lubbock.

Scheaffer, R. L., W. Mendenhall, and R. L. Ott. 2006. Elementary survey sampling. Sixth ed. Duxbury Press, Boston Mass. 464pp.

Skagen, S. K, D. A. Granfors, and C. P. Melcher. 2008. On determining the significance of ephemeral continental wetlands to North American migratory shorebirds. The Auk 125(1):20-29.

Skagen, S. K. and H. D. Oman. 1996. Dietary flexibility of shorebirds in the Western Hemisphere. Canadian Field Naturalist 110:419-44. 
Skagen, S. K. and F. L. Knopf. 1993. Toward Conservation of Midcontinental Shorebird Migrations. Conservation Biology 7(3):533-541.

Skagen, S. K., P. B. Sharpe, R. G. Waltermire, and M. Dillon. 1999. Biogeographical profiles of shorebird migration in midcontinental North America. DTIC Document.

Smith, L. M. and B. R. Winkley. 1996. The response of the Lower Mississippi River to river engineering. Engineering geology 45:433-455

Stafford, J. D., M. M. Horath, A. P. Yetter, C. S. Hine, and S. P. Havera. 2007. Wetland use by mallards during spring and autumn in the Illinois and Central Mississippi River Valleys. Waterbirds 30:394-402.

Thomas, G. H., R. B. Lanctot, and T. Szekely. 2006. Can intrinsic factors explain population declines in North American breeding shorebirds? A comparative analysis. Animal Conservation 9: 252-258.

Twedt, D. J. 2013. Foraging Habitat for Shorebirds in Southeastern Missouri and its Predicted Future Availability. Wetlands 33:1-12.

Twedt, J. D., C. O. Nelms, V. E. Rettig, and S. R. Aycock. 1998. Shorebird use of managed wetlands in the Mississippi Alluvial Valley. The American Midland Naturalist 140(1):140-152.

Williams, B. K., M. D. Koneff, and D. A. Smith. 1999. Evaluation of waterfowl conservation under the North American Waterfowl Management Plan. Journal of Wildlife Management 63:417-440. 


\section{CHAPTER I:}

\section{LOCAL FACTORS AFFECTING SHOREBIRD AND DABBLING DUCK USE ON WETLAND RESERVE PROGRAM EASEMENTS IN THE LOWER MISSISSIPPI ALLUVIAL VALLEY}

The Natural Resource Conservation Service (NRCS) implemented the Migratory Bird Habitat Initiative (MBHI) in summer 2010 to mitigate potential alteration of wetland habitats resulting from the Deepwater Horizon oil spill (NRCS 2013a). The goal of the MBHI was to implement management practices on private farmlands, catfish ponds, and Wetland Reserve Program (WRP) easements in the regions adjacent to the Gulf of Mexico to provide additional habitats for wintering and migrating waterbirds (NRCS 2013a). The WRP is a voluntary easement program established by the 1990 Farm Bill and administered by the Natural Resources Conservation Service to restore, enhance and protect wetlands on private properties. Through financial incentives and technical support, private landowners are encouraged to protect and enhance existing wetlands, as well as retire farmlands from agricultural production and restore them to their previous hydrology (NRCS 2013b). Improving habitat on WRP easements is particularly important, as landowners are not required to provide additional management after initial enrollment/restoration efforts, which in some cases, can influence seed biomass available for waterfowl (Evans-Peters et al. 2012, Olmstead et al. 2013). Priorities for WRP easements enrolled in the MBHI included addressing waterbird food habitats, providing habitat structure, and additional management activities such as planting and/or disking on seasonally flooded, shallow wetlands in the Lower Mississippi Alluvial Valley (LMAV). Comprehensive evaluation of dabbling duck (Anatinae) and shorebird (Charadriiformes) 
habitats and food requirements has revealed the complexities of wetland management for multiple species of migratory waterbirds (Fredrickson and Taylor 1982, de Szalay and Resh 1997, Hagy and Kaminski 2012a,b, Fleming et al. 2012). Until recently, efforts to evaluate WRP management and contribution of WRP wetlands as wildlife habitat in the LMAV have been limited (Fleming et al. 2012, Olmstead et al. 2013), although WRP wetlands have been considered essential to meeting regional conservation goals (King and Keeland 1999, King et al. 2006).

Wetland managers use a combination of soil disturbance, planting, and hydrologic manipulation, known as moist-soil management, on seasonally inundated wetlands to promote plant community composition considered beneficial to dabbling ducks (Fredrickson 1991). Native hydrophytic plants, such as millet (Echinochloa crusgalli), smartweed (Polygonum sp.) and beggarticks (Bidens frondosa), are a desirable plant community because they provide dense cover and food for aquatic invertebrates, as well as produce large quantities of seeds commonly consumed by dabbling ducks, which contain energy, as well as a variety of vitamins and nutrients, and have low decomposition rates (Voigts 1976, Nelson and Kadlec 1984, Fredrickson and Reid 1988a-b, Olson et al. 1995, Kostecke et al. 2005, Dugger et al. 2007). Timing and rates of water-level manipulations are often managed to provide habitats for specific groups of waterbirds, such as shorebirds or marsh birds (Gruiformes) (Fredrickson 1991). Management practices on seasonal wetlands include water level manipulation and disturbance (e.g. mowing, disking, tilling, planting) to set back ecological succession of plant communities and increase seed biomass (Fredrickson 1982, Gray et al. 1999). Public land managers often have the infrastructure and resources to manipulate several 
impoundments concurrently, allowing them to manage for the specific habitat needs of different waterbird groups and ensure food resource availability throughout the season (Fredrickson 1991). Techniques for managing privately owned wetlands are generally restricted to farming operations; however, landowners with the capability to retain or move water onto their properties during autumn can help provide much needed wetland habitat for migrating shorebirds (Twedt et al 1998, Loesch et al 2000). Many private landowners manage wetlands primarily for waterfowl, and as a result, create habitats with water depths and vegetative coverage generally not considered suitable for most shorebird species (Twedt et al. 1998). Additionally, early autumn flooding for shorebirds may affect food availability for wintering and migrating waterfowl, so the compatibility of concurrent management strategies for shorebirds and waterfowl should be considered (Loesch et al. 2000, Greer et al. 2007).

Considerable variation in the type and intensity of management practices on WRP easements can result in a broad range of habitat conditions known to influence waterbird use, including water depth, vegetative community composition and structure, and seed and tuber biomass (Gray et al. 1999, Isola et al. 2000, Webb et al. 2010, Fleming et al. 2012, Olmstead et al. 2013). Water depth is one of the most important habitat characteristics influencing wetland use by waterbirds because it directly determines accessibility of foraging habitats (Helmers 1992 Colwell and Taft 2000, Isola et al. 2000). Shorebirds present throughout the LMAV forage within a limited range of water depths from $0 \mathrm{~cm}$ (dry mud) to $16 \mathrm{~cm}$ because of restrictions of their morphology, such as leg, bill, and neck lengths (Helmers 1992, Collazo et al. 2002). Dabbling duck water depth requirements overlap with shorebirds, however, dabbling ducks also rely on behavioral 
foraging strategies, such as tipping-up and head-submerging, which allow them to effectively forage in water depths up to $25 \mathrm{~cm}$ (Fredrickson and Taylor 1982). While diving waterbirds access to foraging habitat is restricted by a minimum water depth ( $>30$ cm) (Colwell and Taft 2000, Isola et al. 2000), foraging efficiency for wading birds (Ciconiiformes) generally decreases with greater water depths (Gawlik 2002).

Another habitat variable that may influence wetland use by waterbirds is vegetative cover and structure (Weller and Spatcher 1965, Kaminski and Prince 1981, Murkin et al 1982, Smith et al. 2004). Shorebirds use wetlands with vegetative cover ranging from zero to 75 percent, with the majority of shorebird use occurring at sites with less than 25 percent cover (Helmers 1992, Colwell and Dodd 1997, Twedt et al. 1998). In addition, shorter vegetation is thought to increase shorebird visibility of surrounding horizons for predator detection and wetlands with lower percent vegetation are thought to facilitate shorebird foraging activity (Metcalfe 1984, Davis and Smith1998a, DeLeon and Smith 1999, Webb et al. 2010). Vegetative cover has also been shown to be a predictor of dabbling duck abundance during migration, with the greatest dabbling duck abundance in wetlands with approximately 50\% vegetation (Smith et al. 2004, Webb et al. 2010). Furthermore, equal interspersion of open water and vegetation has the potential to support greater plant diversity and resources for aquatic invertebrates, and subsequently provide greater food resources for migrating waterbirds (Weller and Spatcher 1965, Nelson and Kadlec 1984, Smith et al. 2004, Kostecke et al. 2005, Davis and Bidwell 2008)

One of the goals of the MBHI was to increase the amount of available waterbird foods produced by wetlands enrolled in the program through additional habitat 
management. Aquatic invertebrates are the major source of protein that enables survival and reproduction for both waterfowl and shorebirds (Krapu and Reinecke 1992, Skagen and Oman 1996, Davis and Smith 1998a, Davis and Bidwell 2008). Most invertebrate studies are not applicable to different geographic locations because of other factors that can also affect invertebrate populations and communities such as climate, water chemistry, and soil types (Gray et al. 1999, Davis and Bidwell 2008). However, invertebrate biomass and community composition can be a direct indicator of wetland integrity and energy-nutrient availability (Grey et al. 1999, Meyer et al. 2011).

The importance of invertebrates in waterbird diets has led to numerous studies investigating wetland invertebrates and their responses to management (de Szalay et al. 1996, de Szalay and Resh 1997, Gray et al. 1999, Kostecke et al. 2005). Invertebrate densities and diversity can vary temporally, as well as within and between wetlands (Davis and Bidwell 2008). Consequently, waterbirds must adopt flexible foraging strategies to take advantage of spatial and temporal availability of invertebrates (Skagen and Oman 1996, Hamer et al. 2006). Invertebrate abundance can also be positively influenced by increased vegetative growth and decomposition through active wetland management, such as flooding or mowing, and thus providing additional food and habitat structure for invertebrates (Anderson and Smith 2002, Davis and Bidwell 2008, Meyer et al. 2011). Furthermore, the type of mechanical manipulation (i.e. mowing, disking) used to reset vegetative succession in seasonal wetlands can affect total invertebrate biomass and diversity (Gray et al. 1999).

Seeds and tubers of many native herbaceous plants in seasonal wetlands contain lipids, protein, and a variety of nutrients including essential amino acids, vitamins and 
minerals, which are generally absent in agricultural waste grains (Baldassarre et al. 1983, Fredrickson and Reid 1988, Checkett et al. 2002). Waterfowl rely on the nutrients that occur in moist-soil seeds for successful completion of annual life-cycle processes such as molt, migration and reproduction (Smith and Sheeley 1993, Dugger et al. 1994, Bowyer et al. 2005, Nelms et al. 2007). Reliable annual seed production across years, relatively low management costs, greater plant species tolerance to diverse environmental conditions, and seed resistance to decomposition all make moist-soil management an important waterfowl management tool (Laubhan 1992). With the exception of unharvested crops, actively managed seasonal wetlands also have the potential to provide the greatest energy source for dabbling ducks among available foraging habitats (Reinecke and Loesch 1996).

A bioenergetics approach is commonly used to determine carrying capacity for dabbling ducks (i.e. duck energy days [DEDs]/ha) by assuming that seeds and tubers at water depths used by dabbling ducks in a wetland are available as a food source at a given point in time (Reinecke et al. 1989, Loesch et al. 1994). Precise seed biomass estimates can help define the relative value of a wetland for waterfowl by using total metabolizable energy coefficients for seeds and tubers to calculate food energy density (Brasher et al. 2007, Hagy et al. 2011, Straub et al. 2012). The estimation of DEDs within a wetland requires prior knowledge of food density $(\mathrm{kg} / \mathrm{ha})$, total metabolizable energy (TME) of the available foods, and daily existence energy (DEE) of species using the wetland (kcal/day; Kross et al. 2008). This equation is often expressed as:

$$
\mathrm{DED} / \mathrm{ha}=[\text { food density }(\mathrm{kg} / \mathrm{ha})] \mathrm{x}[\mathrm{TME} \text { of available food }(\mathrm{kcal} / \mathrm{g})]
$$

DEE of species (kcal/day) 
Seed and tuber species composition within a wetland may also be of particular interest to wetland managers (Callicutt et al. 2011, Hagy and Kaminski 2012b, Olmstead et al. 2013). Foraging techniques along with varying energy content of different plant species often limits consumption of some available waterfowl foods within a wetland (Miller 1987, Gurd 2006, Tidwell et al. 2013). Dabbling duck food selection, observed through concurrent studies of esophageal content analysis and food availability, can be taxa specific, with birds using some moist-soil plants disproportionate to availability (Fredrickson and Reid 1988, Tidwell et al. 2013). Including seed species that are not consumed by waterfowl can result in overestimation of energetic carrying capacity in wetlands (Hagy and Kaminski 2012b, Olmstead et al. 2013). Estimates of seed biomass availability can be reduced by up to $47 \%$ by removal of plant species considered not beneficial to waterfowl, such as clustervine (Jacquemontia tamnifolia), coffeeweed (Sesbania herbacea), flatsedge Cyperus odoratus), morning-glory (Ipomoea spp.), pigweed (Amaranthus spp.), and spikerush (Eleocharis spp.), from seed and tuber samples collected in seasonal wetlands (Hagy and Kaminski 2012b, Olmstead et al. 2013).

Understanding the effects of management on waterbird food availability and use of privately owned wetlands is a crucial component to meeting population and habitat objectives established by the North American Waterfowl Management Plan and improving conservation easement program management strategies (King et al. 2006). Therefore, the goals of this study were to evaluate the effects of management on moistsoil seed biomass (and subsequent DEDs), invertebrate biomass, and shorebird and waterfowl use on conservation easement (WRP) wetlands in the LMAV of Arkansas and 
Missouri. I used reference wetlands such as WRP wetlands not enrolled in MBHI and long-term actively managed public sites (i.e., federal wildlife refuges, state conservation areas) for comparison with lands enrolled in the MBHI.

\section{Study Area}

Study wetlands were located on private easement lands enrolled in the WRP and actively managed public lands in the LMAV of Arkansas and Missouri. I stratified potential study wetlands by county, identified the 3 counties containing the greatest number of MBHI contracts within each state, and randomly selected individual WRP easements enrolled in the MBHI within these counties (Stafford et al. 2006a, Ratti and Garton 1994, Scheaffer 2006). The 3 counties containing the greatest number of MBHI contracts were Lee, Prairie, and St. Francis counties in Arkansas, and Bollinger, Stoddard and New Madrid counties in Missouri. I randomly apportioned 13 MBHI easements among selected Arkansas and Missouri counties (Figure 1.2). Similarly, I selected 12 reference WRP easements (hereafter WRP) in the same counties that received no additional MBHI funding for implementation of active management practices. I obtained contract information from NRCS district conservationists and landowners and if an easement contained more than one wetland, I randomly selected a single wetland within each easement. I also obtained information from landowners on recent management activities (during the past year), as well as the year each wetland was enrolled in the WRP (Table 2). Specific variables recorded were mowing/disking, active inundation, planting, hunting, and time since WRP enrollment (also called "site age"; 0-10 years or 10-20 years). As an additional reference, I selected 7 sites on public lands that represented long-term, intensively managed seasonal wetlands (Duck Creek Conservation 
Area [1 site] and Mingo National Wildlife Refuge [2 sites] in Missouri; Cache River National Wildlife Refuge [4 sites] in Arkansas).

Area of all private wetlands (MBHI and WRP) ranged from 1.1 - 48.6 ha.

Topography, wetland characteristics, and financial resources varied among landowners, which influenced the type and intensity of management techniques. All study wetlands except one (WRP) had a water control structure, which enabled draining or retaining water on wetlands. Area of study wetlands on public lands ranged from $3.4-43.2$ ha. Water sources for study wetlands originated from rivers, ditches, pumps, runoff, and precipitation. No study wetlands had interconnected hydrology; therefore, wetlands were considered discrete, independent survey and analytical units (Fleming et al 2012). Commonly occurring vegetation in wetlands consisted of native species adapted to seasonal flooding and drainage (moist-soil conditions), including grasses (e.g., Echinochloa spp., Panicum spp.), forbs (Polygonum spp., Bidens spp., Xanthium strumarium), sedges and rushes (Cyperus spp., Juncus spp.), trees and shrubs (Salix nigra), and planted agricultural food plots.

\section{METHODS}

\section{Waterbird Surveys}

I conducted waterbird surveys bi-weekly from 3 August through 16 September 2011 to detect early-autumn migrants and from 3 November 2011 through 24 February 2012 to detect late-autumn migrants and wintering waterbirds. I divided daylight hours into 4 time intervals; sunrise to 0800 hours, 0800-1200 hours, 1200-1600 hours, and 1600 hours to sunset and attempted to conduct bi-weekly surveys at each wetland during a different time interval to reduce any associated temporal biases with bird use (Davis and 
Smith 1998a, Webb et al. 2010). I followed survey protocols described in the Integrated Waterbird Management and Monitoring Program's (IWMM) Monitoring Manual (2010) for whole area counts, and was able to observe at least $70 \%$ of each wetland from available vantage points. During autumn surveys, I recorded all waterbird species present. I recorded only waterfowl species during winter surveys. Upon arrival, I recorded all birds visible in open water from vantage points outside the perimeter of the wetland (Webb et al. 2010). I located and identified individual waterbirds with 8x42 Eagle Optics ${ }^{\circledR}$ binoculars and a Celestron Ultima® spotting scope with $20-60 x$ zoom. To identify birds in large flocks (>100 birds), I recorded species present and visually estimated the number of each species to the nearest 10 (Webb et al. 2010). I spent no longer than 15 minutes at each observation point. I then drove through and around wetlands in an all-terrain vehicle to enhance detection and identification of birds in densely vegetated areas (Twedt and Nelms 1999, Heitmeyer 2006, Kaminski et al. 2006). When wetlands had to be surveyed from more than one location, I observed where birds flew and alighted after being flushed to avoid duplicate bird counts (Kaminski and Prince 1981).

\section{Habitat Sampling}

Shorebirds have been known to avoid moist-soil habitat with high vertical and horizontal vegetation cover (Clark and Greenwood 1987, Davis and Smith1998a). Therefore, during each site visit in autumn, I recorded vegetation height, percent cover, and cover types at two transects perpendicular to the shore line through shorebird foraging habitat strata; mudflats (area of sparsely vegetated moist-soil), shallow water (05cm depth), moderate-shallow (5-10 cm depth), moderate-deep (10-16 cm) and deep water 
$(16 \mathrm{~cm}+$ depth) (Figure 1.3). Each transect was located adjacent to invertebrate sample locations. I used a $1 \mathrm{~m}^{2}$ frame to collect data at each water level strata along each transect. I visually estimated percent cover of vegetation in each of the $1 \mathrm{~m}^{2}$ plots (Wirwa 2009). To quantify plant height I measured the height of two randomly selected plants that made up $>10 \%$ of the groundcover within each $1 \mathrm{~m}^{2}$ plot (Webb et al. 2010). Due to morphological characteristics, shorebirds are only able to use portions of wetland habitat within specific water depths (Helmers 1992). To estimate percent cover of shorebird foraging habitat I measured the total distance from beginning of mudflat to $16-\mathrm{cm}$ water depth (Davis and Smith 1998a) on each transect I selected for vegetation sampling (Figure 1.3). I then delineated wet area edges and transect lengths on printed aerial maps of each wetland unit and estimated the percent of habitat available to shorebirds based on water depth. During winter site visits, I visually estimated percent vegetative cover within $1 \mathrm{~m}^{2}$ of each invertebrate sampling location (see below), total percent vegetative cover for each wetland, total wet area, and recorded any disturbances such as hunting or use of farm equipment during each site visit.

\section{Aquatic Invertebrate Sampling}

I collected invertebrate samples at a subsample of MBHI $(n=6)$ and WRP $(n=6)$ wetlands due to the large number of invertebrate samples collected and time required to process in the lab (approx. 3hr/sample). To assess invertebrate food availability for autumn migrating shorebirds, I collected invertebrate samples at study sites on a biweekly basis from August through mid-September. If shorebirds were present during a site visit, I collected invertebrate samples randomly within the location where I observed the majority of birds within the wetland. If no birds were detected at a site, I sampled and 
recorded habitat data randomly within the dominant vegetative cover in the wetland, excluding any areas with $>50 \%$ vegetative cover to prevent collecting invertebrate samples from microhabitats that were unlikely to be used by shorebirds (Davis and Smith 1998a). I also restricted sample locations to water depths at which shorebirds are expected to forage (mudflat to $16 \mathrm{~cm}$ water depth). During each site visit, I collected two 5-cm deep x 10-cm diameter soil core samples $\left(392.85 \mathrm{~cm}^{3}\right.$; Sherfy et al. 2000, Hamer et al. 2006, Davis and Bidwell 2008) to quantify benthic invertebrates. I washed soil samples through a $500 \mu \mathrm{m}$ mesh sieve bucket while in the field. I also collect two samples of nektonic invertebrates with a $500 \mu \mathrm{m}$ rectangular sweep net. I lowered the net into the water and dragged it along the bottom for a distance of $1.1 \mathrm{~m}\left(0.5 \mathrm{~m}^{2}\right.$ area $)$ (Wehrle et al. 1995, Gray et al. 1999). Soil core and water-column samples were stored in plastic storage bags with at least $70 \%$ ethanol and returned to the lab for processing (Murkin et al. 1994, Anderson et al. 2000).

To estimate invertebrate availability for waterfowl during winter I used a rectangular sweep net $(46 \mathrm{~cm} \times 20 \mathrm{~cm} ; 500 \mu \mathrm{m})$ to sample aquatic invertebrates bi-weekly from November through February ( $n=4$ sweeps/site/visit; Wehrle et al. 1995, Hagy and Kaminski 2012a). I stratified sites by dominant cover types: open water $(<50 \%$ vegetative cover) and vegetation (>50\% vegetative cover) and collected 2 sweep samples at random locations within each cover type. If waterfowl were present, I collected samples and habitat data where the majority of birds were located within the wetland. If no birds were detected at a site, I collected samples randomly within dominant cover types at water depths $(15-60 \mathrm{~cm})$ which waterfowl are expected to forage (Dubowy 1988, Isola et al. 2000). According to published protocol, I vertically lowered the sweep net 
until it was pushed firmly against the substrate and bounced it along the bottom for $1.0 \mathrm{~m}$ to sample a $0.5 \mathrm{~m}^{2}$ area (Cheal et al. 1993, Gray et al. 1999, Hagy and Kaminski 2012a). I transported each sweep sample in a plastic bag for storage in at least $70 \%$ ethyl alcohol and later added rose bengal to facilitate sorting (Murkin et al. 1994, Anderson et al. 2000).

\section{Moist-soil seed sampling}

I estimated moist-soil seed and tuber biomass by collecting 10 soil core samples at each site twice during late autumn 2011 through winter 2012 (Kross et al. 2008, EvansPeters et al. 2012, Olmstead et al. 2013). I collected cores at random locations along a transect within each wetland once in October when a majority of the seeds had dehisced (Reinecke and Hartke 2005, Kross et al. 2008) and once during late February after most waterfowl had migrated north. Previous research (Olmstead 2010, Evans-Peters 2010) found $90 \%$ of seed biomass from $10 \mathrm{~cm}$ soil samples located in the top $5 \mathrm{~cm}$; therefore, I extracted $5 \mathrm{~cm}$ depth $\mathrm{x} 10 \mathrm{~cm}$ diameter $\left(392.85 \mathrm{~cm}^{3}\right)$ cores at each sampling location (Kross et al. 2008, Greer et al. 2009). After each core was extracted, I placed it in a plastic bag and stored it at $-10^{\circ} \mathrm{C}$ until further processing (Kross et al. 2008, Olmstead et al. 2013).

\section{Sample processing}

To facilitate sorting and identification, I stained invertebrate samples with rose bengal solution for 12-24 hours prior to processing (Sherfy et al 2000, Bolduc and Afton 2003). I filtered samples with running water through a series of sieves of decreasing mesh sizes $(500 \mu \mathrm{m}$ and $100 \mu \mathrm{m})$ to separate samples into coarse and fine samples, and facilitate sorting and identification (Bolduc and Afton 2003). Coarse samples were 
processed entirely, whereas fine samples were subsampled (1:2 to 1:32 of total) using a Folsom plankton splitter (Aquatic Research Instruments) prior to removal of macroinvertebrates (Whiting et al. 2011). The percent composition in the fine subsample was extrapolated and added to the coarse sample invertebrate abundance and biomass to estimate total fine sample invertebrate abundance and biomass in the overall sample. I catalogued invertebrates by family and reported biomass $(\mathrm{kg} / \mathrm{ha})$ estimates for each taxon (Hagy and Kaminski 2012a). To obtain biomass estimates, I oven-dried specimens at $55^{\circ} \mathrm{C}$ for $\geq 24 \mathrm{~h}$ to a constant mass (to the nearest $0.01 \mathrm{mg}$ ) (Anderson and Smith 2000). Secondary production for each family was estimated using the size-frequency method and published annual or seasonal production/biomass $(\mathrm{P} / \mathrm{B})$ ratios for macroinvertebrates (Stagliano and Whiles 2002). According to published protocol, size-specific dry mass was estimated for all resident taxa using length-weight relationships obtained from Benke et al. (1999), Stagliano and Whiles (2002), and Evans-White et al. (2003). When $\mathrm{P} / \mathrm{B}$ estimates for families were not available, I used estimates for individual species within that family that have been observed in habitats with similar environmental characteristics. I then calculated total bi-weekly and seasonal production for each study wetland.

I thawed each soil core sample overnight and then soaked the sample for 3-5 hours in a solution of 3\% hydrogen peroxide, to allow for clay dispersion (Hagy and Kaminski 2012b). I washed soil cores through a series of 2 sieves ( \#50 [0.03 mm] and $\# 10[1.65 \mathrm{~mm}])$ to segregate the sample by size and dried to a constant mass at approximately $87^{\circ} \mathrm{C}$ for $\geq 24$ hours (Kross et al. 2008, Hagy and Kaminski 2012b). I weighed and recorded dry mass (to the nearest $.01 \mathrm{mg}$ ) for the coarse and fine portion of 
each sample. I placed the contents of the fine sieve on grid paper and select one quarter of the sample for sorting and weighing. I multiplied the sub-sample by 4 (25\% subsample) and added to the mass of the larger material to estimate total dry biomass for each core (Reinecke and Hartke 2005, Kross et al. 2008). I converted seed and tuber biomass for each core to kilograms per hectare (Kross et al. 2008).

\section{Data Analysis}

I analyzed data from each season separately because of differences in environmental conditions, sampling methodologies, and avian community composition. I converted autumn shorebird counts (birds/ha), invertebrate biomass ( $\mathrm{kg} / \mathrm{ha})$ and production $(\mathrm{kg} / \mathrm{ha})$ to densities by using total shorebird foraging habitat (ha) estimates. I converted winter waterfowl counts, as well as invertebrate and seed variables to densities using total wet area. All tests were conducted using SAS/STAT ${ }^{2}$ 9.2, and $\alpha=0.05$ significance level (SAS Institute 2012). All means were calculated using the SAS least squares means statement (LSMEANS), rounded to the nearest 0.01 , and reported as $\bar{x}( \pm$ $\mathrm{SE})$.

I used an Analysis of Variance (ANOVA) to test effects of the following variables on autumn shorebird densities using the MIXED procedure (PROC MIXED; SAS Institute 2012): wetland type (WRP, MBHI, or Public), individual management activities (mowing/disking, planting, and active inundation), invertebrate biomass, bi-weekly invertebrate production and site age. I tested for the interaction of each factor and site visit, and designated site as a random effect.

I used an Analysis of Variance (ANOVA) to test effects of the following variables on winter dabbling duck densities using the MIXED procedure (PROC MIXED; SAS 
Institute 2012): wetland type (WRP, MBHI, or Public), individual management activities (mowing/disking, planting, and active inundation), invertebrate biomass, bi-weekly invertebrate production, seed biomass, the presence of hunting activities, and site age. I tested for the interaction of each factor and site visit, and designated site as a random effect.

I converted seed biomass to DEDS by following methods described by Reinecke et al. (1989) and this equation:

$$
\mathrm{DED} / \mathrm{ha}=\frac{[\text { food density }(\mathrm{g} / \mathrm{ha})] \times[\mathrm{TME} \text { of available food }(\mathrm{kcal} / \mathrm{g})]}{\text { DEE of species }(\mathrm{kcal} / \mathrm{day})}
$$

To calculate DEDs, I used individual food density estimates for each wetland, and established values for mean TME of moist-soil seeds ( $2.5 \mathrm{kcal} / \mathrm{g}$ [Kaminski 2003]), and mean daily energy requirements estimates provided by the Lower Mississippi Valley Joint Venture for the 8 dabbling duck species that typically use seasonal wetlands in the LMAV (294.35 kcal/day; Reinecke and Uihlein 2006, Reinecke and Kaminski 2007). I used an Analysis of Variance (ANOVA) to test effects of the following variables on seed biomass using the MIXED procedure (PROC MIXED; SAS Institute 2012): wetland type (WRP, MBHI, or Public), individual management activities (mowing/disking, planting, and active inundation), and site age. I tested for the interaction of each factor and site visit, and designated site as a random effect. I used PROC GLM to test the effects of wetland type and management on DEDs.

My assessment of invertebrate communities was coarse-grained (i.e., class, order, or family), and I identified invertebrates to family when possible (Wehrle et al. 1995). I was not able to identify invertebrates to species and determine species richness. I omitted 
the order Hemiptera from secondary production estimates because of inability to efficiently distinguish between adults and juveniles. I used an ANOVA to test effects of the following variables on invertebrate biomass using the MIXED procedure (PROC MIXED; SAS Institute 2012): wetland type (WRP, MBHI, or Public), individual management activities (mowing/disking and active inundation), and site age. I tested for the interaction of each factor and site visit, and designated site as a random effect.

\section{RESULTS}

\section{Waterbirds}

From August 3 through September 16 I conducted 85 avian surveys and observed 13 shorebird species (432 individuals), 4 wading bird species (Ciconiiformes; 455 individuals), 6 waterfowl species (483 individuals), 2 secretive marsh bird species (Gruiiformes; 8 individuals), and 2 other waterbird species (13 individuals). Approximately $99 \%$ of the shorebirds species observed were comprised of killdeer (Charadrius vociferous, 48\%), least sandpipers (Calidris minutilla, 14\%), black-necked stilts (Himantopus mexicanus, 12\%), greater yellowlegs (Tringa melanoleuca, 10\%), solitary sandpipers (Tringa solitaria, 4\%), Wilson's snipe (Gallinago delicata, 4\%), semipalmated sandpipers (Calidris pusilla, 4\%), Baird's sandpipers (Calidris bairdii, $2 \%$ ), and pectoral sandpipers (Calidris melanotos, $1 \%$ ). The most common wading birds and waterfowl were great egrets (Ardea alba), blue-winged teal (Anas discors), Canada geese (Branta canadensis), and great blue herons (Ardea herodias). Drought conditions combined with landowner reluctance to flood sites until winter resulted in approximately $50 \%$ of sites being completely dry during almost the entire shorebird survey period. 
There was no difference in shorebird densities among wetland types $\left(\mathrm{F}_{2,26}=1.27\right.$, $p=0.30$; Table 1.2). Mean shorebird densities were $2.18( \pm 1.55)$ birds/ha at WRP wetlands, $3.08( \pm 1.34)$ birds/ha at MBHI wetlands, and $1.56( \pm 1.36)$ birds/ha at public wetlands. There was also no difference in shorebird species richness among wetland types $\left(\mathrm{F}_{2,26}=2.63, p=0.09\right)$. Mean shorebird species richness at WRP wetlands was $1.19( \pm 0.19)$ species/ha, $2.03( \pm 1.18)$ at MBHI wetlands, and $1.40( \pm 1.40)$ at public wetlands. Management activities, including mowing $\left(\mathrm{F}_{1,13}=0.00, p=0.97\right)$ and active inundation $\left(\mathrm{F}_{1,13}=1.42, p=0.25\right)$, did not influence shorebird densities. Additionally, site age had no effect on shorebird densities $\left(\mathrm{F}_{1,13}=0.01, p=0.94\right)$. Shorebird densities were not influenced by invertebrate biomass $\left(\mathrm{F}_{1,20}=0.04, p=0.84\right)$ or production $\left(\mathrm{F}_{1,19}=\right.$ $0.01, p=0.91)$. Shorebird densities $\left(\mathrm{F}_{1,49}=8.42, p \leq 0.05\right)$ were influenced by percent vegetative cover, with greater densities at sites with lower percent cover (Figure 1.3). Shorebird densities during autumn were also greater at sites with shorter vegetation height $\left(\mathrm{F}_{1,49}=6.82, \mathrm{p} \leq 0.05\right.$; Figure 1.4), with most shorebirds using wetlands containing mean vegetation height $<30 \mathrm{~cm}$.

I conducted 420 wintering waterfowl surveys from 3 November 32011 through 24 February 2012. I observed 31,247 waterfowl and recorded 20 waterfowl species with 94\% of total birds consisting of mallards (Anas platyrhynchos, 60\%), Northern shovelers (A. cylpeata, 13\%), gadwall (A. strepera, $8 \%$ ), green-winged teal (A. crecca, 5\%), ringnecked ducks (Aythya collaris, 5\%), and Northern pintails (A. acuta, 3\%). Waterbird species composition was similar to previous studies completed at WRP easements (Hicks 2003, Fleming 2010). Dabbling duck densities differed among wetland types $\left(\mathrm{F}_{2,30}=\right.$ 3.22, $p \leq 0.05)$. Duck densities at MBHI wetlands (2.89 [ \pm 1.23$]$ birds/ha) were 2.1 
times greater than at WRP wetlands $(1.37[ \pm 1.24]$ birds/ha; $p<0.05)$; but did not differ from densities at public wetlands $(1.82[ \pm 1.33]$ birds/ha; $p=0.20)$. Dabbling duck species richness did differ among wetland types $\left(\mathrm{F}_{2,30}=3.22, p=0.06\right)$. Dabbling duck species richness was greatest at MBHI wetlands (1.40 [ \pm 1.06$]$ species/ha), followed by WRP $(1.14[ \pm 1.06]$ species/ha) and public (1.14 [ \pm 1.08$]$ species/ha).

Regardless of wetland type, dabbling duck densities were approximately 2.6 times greater at private wetlands $(\mathrm{MBHI}$ and $\mathrm{WRP})$ that were actively inundated $\left(\mathrm{F}_{1,29}=15.66\right.$, $p \leq 0.05$; Figure 1.5), compared to sites that were not inundated. Additionally, wetlands that were planted with moist-soil seeds had dabbling duck densities 1.8 times greater than sites where moist-soil seeds were not planted $\left(\mathrm{F}_{1,29}=4.50, p \leq 0.05\right.$; Figure 1.6). Seed biomass did not influence dabbling duck densities $\left(\mathrm{F}_{1,24}=0.05, p=0.82\right)$. Likewise, invertebrate biomass $\left(\mathrm{F}_{1,147}=0.94, p=0.33\right)$ or production $\left(\mathrm{F}_{1,113}=1.92, p=0.17\right)$ had no effect on dabbling duck densities. Mowing did not influence dabbling duck densities $\left(\mathrm{F}_{1,29}=0.06, p=0.80\right.$; Figure 1.6). However, dabbling duck densities $\left(\mathrm{F}_{1,124}=4.39, p \leq\right.$ 0.05) were influenced by percent vegetative cover, with the greatest densities occurring at sites with approximately 50\% cover (Figure 1.7). Dabbling duck densities were 1.8 times greater at wetlands with hunting activities, compared to sites with no hunting activity $\left(F_{1,29}=5.55, p \leq 0.05\right)$. Site age had no influence on dabbling duck densities $\left(F_{1,29}=\right.$ $0.17, p=0.68)$.

\section{Aquatic Invertebrates}

Invertebrate biomass (kg/ha) data were left skewed, therefore I log transformed the data (Zar 1999). Additionally, WRP, MBHI, and public wetlands were not always inundated or accessible concurrently during each season. Only one public site was 
inundated in August and early-September, therefore I omitted public sites as a wetland type from autumn analyses. From August 3 through September 16, I collected 85 total invertebrate samples at 9 wetlands to quantify autumn shorebird food availability. Families Planorbidae (66\%), Corixidae (22\%), Physidae (4\%), Dytiscidae (2\%), Palaemonidae (2\%), Chironomidae (2\%), Hydrophilidae (1\%), and Haliplidae (1\%) accounted for 99\% of total biomass in sweep samples. Families Belostomatidae (45\%), Planorbidae (36\%), Physidae (4\%), Hirudidae (3\%), Lumbriculidae (3\%), Corixidae (2\%), Dytiscidae (1\%) accounted for $98 \%$ of total biomass in core samples. Mean invertebrate biomass was $23.88 \pm 1.48 \mathrm{~kg} / \mathrm{ha}$ (range $1.8-1895.9 \mathrm{~kg} / \mathrm{ha}$ ) in benthic core samples and $5.85 \pm 1.48 \mathrm{~kg} / \mathrm{ha}$ (range $0.01-125.47 \mathrm{~kg} / \mathrm{ha}$ ) in nektonic sweep samples. Mean core and sweep familial richness were $2.8( \pm 1.1)$ and $5.0( \pm 1.1)$ families/ha, respectively. Core biomass estimates were over 4 times greater than sweep biomass estimates $\left(\mathrm{F}_{1,16}=6.32 ; \mathrm{p} \leq 0.05\right)$. Conversely, sweep familial richness was $50 \%$ greater than core estimates $\left(\mathrm{F}_{1,16}=18.75 ; \mathrm{p} \leq 0.05\right)$. I found no effects of wetland type on invertebrate biomass $\left(\mathrm{F}_{1,6}=1.15, p=0.32\right)$. Similarly, invertebrate biomass was not affected by mowing $\left(\mathrm{F}_{1,6}=0.20, p=0.67\right)$, active inundation $\left(\mathrm{F}_{1,6}=1.40, p=0.28\right)$, and site age $\left(\mathrm{F}_{1,6}=0.57, p=0.48\right)$.

From November 3 through February 24, I collected a total of 516 winter invertebrate samples from 19 wetlands. Winter invertebrate biomass consisted exclusively of sweep samples and ranged from $0.0-60.29 \mathrm{~kg} / \mathrm{ha}$. Families Planorbidae (21\%), Cambaridae (17\%), Physidae (9\%), Asellidae (6\%), Chironomidae (6\%), Daphniidae (6\%), Naididae (5\%), Dytiscidae (5\%), Palaemonidae (5\%), Corixidae (4\%), Hyrdophilidae (3\%), Copepoda (2\%), Gammaridae (2\%), and Belostomatidae (1\%) 
comprised $90 \%$ of the total biomass in winter sweep samples. I observed 42 more families in winter sweep samples than in autumn sweep samples. Invertebrate familial richness varied from $0.00-14.00$ families/ha. I found no effects of wetland type on winter invertebrate biomass $\left(\mathrm{F}_{2,16}=0.17, p=0.85\right)$. Similarly, mowing $\left(\mathrm{F}_{1,17}=0.56, p=\right.$ $0.46)$ and active inundation $\left(\mathrm{F}_{1,17}=0.92, p=0.35\right)$ had no effect on invertebrate biomass. Invertebrate biomass did not differ between younger and older WRP wetlands (i.e. site age; $\left.\mathrm{F}_{1,17}=2.60, p=0.13\right)$.

\section{Moist-soil seeds}

Initial seed biomass in autumn 2011 ranged from $34-1021 \mathrm{~kg} / \mathrm{ha}$ at private wetlands and $89-748 \mathrm{~kg} / \mathrm{ha}$ at public wetlands. Mean initial seed biomass was 238.36 $( \pm 1.26) \mathrm{kg} / \mathrm{ha}$ at WRP wetlands, $233.80( \pm 1.27) \mathrm{kg} / \mathrm{ha}$ at MBHI wetlands, and $255.16( \pm$ 1.38) $\mathrm{kg} / \mathrm{ha}$ at public wetlands. Seed biomass estimates were not different among wetland types $\left(\mathrm{F}_{2,26}=0.02, p=0.98\right)$. Seed biomass did not differ among management practices of mowing/disking $\left(\mathrm{F}_{1,27}=0.01, p=0.93\right)$ or active inundation $\left(\mathrm{F}_{1,27}=2.53, p\right.$ $=0.12)($ Figure 1.8). However, seed biomass was 1.8 times greater at sites that were planted, compared to sites that received no planting treatment $\left(\mathrm{F}_{1,27}=4.72, \mathrm{p} \leq 0.05\right.$; Figure 1.9). Mean seed production estimates were approximately $21 \%$ greater at MBHI wetlands (684 \pm 1.39 DEDs) than at WRP wetlands (563 \pm 1.41 DEDs). Mean public wetland seed production was $764( \pm 1.59)$ DEDs. In February 2012, mean remaining seed biomass did not differ among wetland types $\left(\mathrm{F}_{2,27}=0.16, p=0.85\right)$. Mean remaining seed biomass was $136.92( \pm 1.40) \mathrm{kg} / \mathrm{ha}$ at WRP wetlands, $106.95( \pm 1.38)$ $\mathrm{kg} / \mathrm{ha}$ at MBHI wetlands, and $167.10( \pm 1.57) \mathrm{kg} / \mathrm{ha}$ at public wetlands. Seed depletion was correlated with total seed biomass at all wetlands $\left(R^{2}=0.60, \mathrm{~F}=17.0, \mathrm{p} \leq 0.05\right.$; 
Figure 1.9). Mean percent seed depletion was $29 \%$ at MBHI wetlands, $24 \%$ at WRP wetlands, and $30 \%$ at public wetlands.

\section{DISCUSSION}

Several studies have documented greater waterfowl densities on actively managed wetlands (Haukos and Smith 1993, Anderson and Smith 1999, Kaminski et al. 2006), therefore this study focused on quantifying the effects of moist-soil management on waterbird use of private lands enrolled in conservation easement programs. Through MBHI funded management activities, private wetlands attracted greater mean dabbling duck densities than the public reference sites during winter 2011-2012. Among management activities, active inundation had the greatest impact on dabbling duck densities, followed by moist-soil seed planting and mowing (Figure 1.6). I found no patterns of shorebird use among study wetland types, however, likely due to autumn drought conditions.

Increased dabbling duck use of actively managed wetlands is often attributed to increased food production by planting moist-soil seeds (Reinecke et al. 1989, Kaminski et al. 2006). Seed biomass estimates at all private wetlands $(294.28[ \pm 44.77] \mathrm{kg} / \mathrm{ha})$ were similar to those reported for previous studies conducted at public (496 kg/ha, Kross et al. 2008) and private wetlands (263.5 [ \pm 18.5$] \mathrm{kg} / \mathrm{ha}$, Olmstead et al. 2013) in the LMAV. I did not account for seed species composition and therefore may have included nonbeneficial seed species in biomass estimates. Indeed, Olmstead et al. (2013) reported that up to $47 \%$ of seed biomass in soil core samples may consist of invasive and other seeds that aren't known to be consumed by waterfowl. 
I found no relationship between seed biomass and dabbling duck density, despite the positive influence of planting moist-soil seeds on dabbling duck densities (Figure 1.6) and a strong association between total seed biomass and seed depletion (Figure 1.9). It was not always feasible to conduct avian surveys to coincide with when optimal waterbird densities are expected to be observed ( 3 hours after sunrise and 3 hours before sunset; Hagy and Kaminski 2012a), so I randomized waterbird survey times at each site visit. Waterfowl have also been known to feed at night (Anderson and Smith 1999), but I was unable to observe nocturnal waterbird use at my study wetlands. Consequently, my inability to survey for all sites at times when waterfowl were most likely to be present may have confounded my ability to detect a relationship between food availability and dabbling duck densities.

There is opposing evidence that waterfowl abundance is not always influenced by food quantity (Percival et al. 1998, Hagy and Kaminski 2012b). Dabbling ducks at my study wetlands could have responded to habitat variables other than food abundance such as survival probability (Fretwell and Lucas 1970, Hagy and Kaminski 2012b). In one study, birds were more influenced by risk of predation than food abundance in foraging sites (Martin 1995). Habitat selection is likely the result of complex decision-making processes to maximize fitness based on individual nutrient requirements, predation risk, social status, and variable metabolic requirements (Percival et al. 1998, Nolet et al. 2001, van Gils et al. 2004, Johnson, 2007, Morris and Mukherjee 2007, Castillo-Guerrero et al. 2009). The observation of dabbling duck behaviors at winter sites may help clarify the relationship between dabbling duck use and WRP wetland characteristics (Morris and Mukherjee 2007, Hagy 2010). 
Hunter disturbance at public wetlands has typically had a negative effect on dabbling duck densities (Bregnballe and Madsen 2004, Dooley et al. 2010, Webb et al 2010), whereas I observed relatively high densities at hunted private wetlands (Figure 1.5). Landowners who allow hunting on their properties are more likely to implement wildlife management activities to maximize hunting success (Geist et al. 2001), and because hunters feel it is their duty as good sportsman to conserve wildlife (Burger and Sanchez 1999, Holsman 2000). In fact, landowners in this study refused access on several occasions during the hunting season to prevent any additional disturbance to waterfowl.

Moderate drought conditions in Arkansas and Missouri during autumn 2011 (NOAA 2012) resulted in low shorebird habitat availability on private lands. Moreover, many landowners with pumping capabilities did not initiate wetland inundation until waterfowl season (mid-November), which resulted in over $50 \%$ of wetlands being completely dry during the shorebird survey period. Migrating shorebirds encounter spatially and temporally fluctuating wetland habitat availability during migration along with unpredictable food supplies (Skagen and Knopf 1993; Skagen et al. 2008). Shorebirds exhibit low site fidelity and greater diet flexibility and opportunistic foraging strategies as a result of the unpredictable nature of habitat and prey availability (Davis and Smith 2001; Skagen et al. 2008; Colwell 2010). Consequently, the occurrence and movement patterns of migratory shorebirds through interior North America can vary greatly within and among migration periods (Colwell 2010). Shorebirds likely adapt their migration strategies to local and regional environmental conditions (Lehnen 2010) and seek out more reliable resources such as wetland complexes, lacustrine, and riverine 
habitats during dry conditions (Skagen and Knopf 1994, DeLeon and Smith 1999, Erwin 2002). The exceedingly unpredictable availability of individual wetlands for autumn stopover habitat implies a need to focus on providing habitat at a broader scale (Skagen et al. 2008, Albanese et al. 2012, Twedt 2013).

I observed that invertebrate production (Chapter 2) and seed biomass were improved through MBHI management, but production results were not consistent across seasons. Another study found that in years with above average precipitation, passively managed WRP wetlands in the LMAV can produce more seed biomass than those that were actively managed (Olmstead et al. 2013). Research indicates that migratory waterbirds and their foods are highly adapted to natural variability (Fredrickson 1991, Skagen and Knopf 1993, Wehrle et al. 1995, Batzer 2013). A diverse habitat with a hydrological regime that reflects natural variation, such as WRP easements, are less likely predictable but can potentially be more productive than stable or predictable systems such as long term managed wetlands (Fredrickson 1991, Brasher et al. 2007, Batzer 2013, Olmstead et al. 2013). Studies have shown us that both passively and actively managed WRP wetlands have benefits regarding migratory waterbird habitat and diet requirements (Brasher et al. 2007, Fleming et al. 2012, Olmstead et al. 2013).

Despite evidence that management can improve habitat conditions and attract greater densities of waterbirds, management and habitat varies greatly among WRP wetlands and probably does not fully explain variation in waterbird densities (Pankau 2008). The scale at which studies are conducted can influence the interpretation of results and may result in inappropriate conclusions (Wiens 1989, Albanese et al. 2012). My study considers the effects of MBHI management one year after the program was 
implemented. Wetland restoration and management effects on waterbirds and food availability at WRP wetlands may not be consistent across years due to annual differences in hydrological periods, therefore similar studies should be continued to determine long-term effects. (King et al. 2006). In Chapter 3, I have investigated the likelihood that variation in bird densities may be further explained by landscape scale features such as land-use composition surrounding each wetland and distance to other wetland habitats (Webb et al. 2010, Albanese et al. 2012).

\section{MANAGEMENT IMPLICATIONS}

Management activities at WRP wetlands have the potential to increase seed biomass and invertebrate production, and create habitat conditions similar to long-term publicly managed wetlands within a relatively short time frame. I observed greater dabbling duck use at WRP wetlands enrolled in the MBHI compared to WRP wetlands not enrolled, however shorebird use at study wetlands did not differ among wetland type. Drought conditions may have resulted in greater shorebird use at wetland complexes, lakes, and rivers, reducing our ability to detect use at WRP wetlands (DeLeon and Smith 1999). However, WRP wetlands are still important resources for shorebirds and the management of relevant habitats should be encouraged wherever possible (Loesch et al. 2000). If a private land biologist wanted to focus a portion of MBHI funding on shorebird habitat, a reliable source of water is critical, especially in years with low precipitation where late-spring drawdowns are accelerated by high rates of evapotranspiration. Semi-permanent wetlands, which stay inundated for a few years at a time, may be a suitable alternative for shorebird habitat in dry years. 
For seasonal wetlands, more than a few years of drought conditions can stimulate the growth and eventual takeover by invasive or unwanted vegetation (Brasher et al. 2007, Evans-Peters et al. 2012), thus outcompeting beneficial moist-soil seed producers. Additional management such as disking during dry periods can help alleviate problematic vegetation. While it may seem counterintuitive, drought conditions can also be beneficial to wintering waterbirds. Dry soil allows plants to establish more robust root systems (Fredrickson 1991) and organic matter to fully dry which accelerates bacterial decomposition when inundated, providing a good food source for invertebrates. Considering the complex and variable nature of seasonal wetlands, I suggest an adaptive management approach for MBHI funded wetlands (Lyons et al. 2008, Benke 2013). Monthly monitoring of vegetative and invertebrate responses of each wetland to management will help to guide future management decisions (Fleming 2012). It may be more efficient to allocate more resources into fewer WRP easements to ensure each wetland is being managed efficiently and meeting the objectives established by the MBHI. 


\section{LITERATURE CITED}

Albanese, G., C. A. Davis, and B. W. Compton. 2012. Spatiotemporal scaling of North American continental interior wetlands: implications for shorebird conservation. Landscape Ecology 27:1465-1479.

Anderson, J. T. and L. M. Smith. 1998. Protein and energy production in playas: Implications for migratory bird management. Society of Wetland Scientists $18: 437-446$.

Anderson, J. T. and L. M. Smith. 1999. Carrying capacity and diel use of managed playa wetlands by nonbreeding waterbirds. Wildlife Society Bulletin 27:281-291.

Anderson, J. T. and L. M. Smith. 2002. The effect of flooding regimes on decomposition of Polygonum pensylvanicum in playa wetlands (Southern Great Plains, USA). Aquatic botany 74:97-108.

Baldassarre, G. A., R. J. Whyte, E. E. Quinlan, and E. G. Bolen. 1983. Dynamics and quality of waste corn available to postbreeding waterfowl in Texas. Wildlife Society Bulletin 11:25-31.

Benke, A. C. and A. D. Huryn. 2010. Benthic invertebrate production-facilitating answer to ecological riddles in freshwater ecosystems. Journal of North American Benthological Society 29:264-285.

Benke, A. C., A. D. Huryn, L. A. Smock, and J. B. Wallace. 1999. Length-mass relationships for freshwater macroinvertebrates in North America with particular reference to the southeastern United States. Journal of the North American Benthological Society 18:308-343.

Bowyer, M. W., J. D. Stafford, A. P. Yetter, C. S. Hine, M. M. Horath, and S. P. Havera. 2005. Moist-soil plant seed production for waterfowl at Chautauqua National Wildlife Refuge, Illinois. The American Midland Naturalist 154:331-341

Bolduc, F. and A. D. Afton. 2003. Effects of structural marsh management and salinity on invertebrate prety of waterbirds in marsh ponds during winter on the Gulf Coast Chenier Plain. Wetlands 23:897-910.

Brasher, M. G., J. D. Steckel, and R. J. Gates. 2007. Energetic carrying capacity of actively and passively managed wetlands for migrating ducks in Ohio. The Journal of Wildlife Management 71:2532-2541.

Bregnballe, T. and J. Madsen. 2004. Tools in waterfowl reserve management: effects of intermittent hunting adjacent to a shooting-free core area. Wildlife Biology 10:261-268.

Buler, J. J., M. L. Sieges, and J. A. Smolinsky. 2013. Assessment of Bird Response to the NRCS Migratory Bird Habitat Initiative using Weather Surveillance Radar: Final 
Report. Department of Entomology and Wildlife Ecology, University of Delaware, Newark, DE.

Callicutt, J. T., H. M. Hagy, and M. L. Schummer. 2011. The Food Preference Paradigm: A Review of Autumn-Winter Food Use by North American Dabbling Ducks (1900-2009). Journal of Fish and Wildlife Management 2:29-40.

Castillo-Guerrero, J. A., G. Fernández, G. Arellano, and E. Mellink. 2009. Diurnal abundance, foraging behavior and habitat use by non-breeding Marbled Godwits and Willets at Guerrero Negro, Baja California Sur, México. Waterbirds 32:400407.

Cheal, F., J. Davis, J. Growns, J. Bradley, and F. Whittles. 1993. The influence of sampling method on the classification of wetland macroinvertebrate communities. Hydrobiologia 257:47-56.

Checkett, J. M., R. D. Drobney, M. J. Petrie, and D. A. Graber. 2002. True metabolizable energy of moist-soil seeds. Wildlife Society Bulletin:1113-1119.

Clark, R. G. and H. Greenwood. 1987. A circular" ring-angel" movement by fieldfeeding waterfowl. Wilson Bulletin 99:722-723.

Collazo, J. A., D. A. O’Harra, and C. A. Kelly. 2002. Accessible habitat for shorebirds: Factors influencing its availability and conservation implications. Waterbirds 25:13-24.

Colwell, M. A. 2010. Shorebird ecology, conservation, and management. University of California Press, Berkley.

Colwell, M. A. and O. W. Taft. 2000. Waterbird communities in managed wetlands of varying water depth. Waterbirds 23:45-55.

Colwell, M. A. and S. L. Dodd. 1997. Environmental and habitat correlates of pasture use by nonbreeding shorebirds. Condor 99:337-344.

Davis, C. A. and J. R. Bidwell. 2008. Response of aquatic invertebrates to vegetation management and agriculture. Wetlands 28:793-805.

Davis, C. A., and L. M. Smith. 1998. Ecology and management of migrant shorebirds in the Playa Lakes Region of Texas. Wildlife Monographs 140:1-45.

De Leon, M. T. and L. M. Smith. 1999. Behavior of migrating shorebirds at North Dakota prairie potholes. Condor 101:645-654.

De Szalay, F. A., D. P. Batzer, and V. H. Resh. 1996. Mesocosm and macrocosm experiments to examine effects of mowing emergent vegetation on wetland invertebrates. Environmental Entomology 25:303-309. 
De Szalay, F. A. and V. H. Resh. 1997. Responses of wetland invertebrates and plants important in waterfowl diets to burning and mowing of emergent vegetation. Wetlands 17:149-156.

Dooley, J. L., T. A. Sanders, and P. F. Doherty. 2010. Mallard Response to Experimental Walk-In and Shooting Disturbance. The Journal of Wildlife Management 74:1815-1824.

Dugger, B. D., K. J. Reinecke, and L. H. Fredrickson. 1994. Late winter survival of female mallards in Arkansas. The Journal of Wildlife Management 58:94-99.

Erwin, R. M. 2002. Integrated management of waterbirds: beyond the conventional. Waterbirds 25:5-12.

Evans-Peters, G. R. 2010. Assessing biological values of Wetlands Reserve Program wetlands for wintering waterfowl. Thesis, Oregon State University, Corvallis, USA.

Evans-White, M. A., W. K. Dodds, and M. R. Whiles. 2003. Ecosystem significance of crayfishes and stonerollers in a prairie stream: functional differences between cooccurring omnivores. Journal of the North American Benthological Society 22:423-441.

Fleming, K. S., R. M. Kaminski, T. E. Tietjen, M. L. Schummer, G. N. Ervin, and K. D. Nelms. 2012. Vegetative Forage Quality and Moist-soil Management on Wetlands Reserve Program Lands in Mississippi. Wetlands 32:919-929.

Fredrickson, L. H. 1991. Strategies for water level manipulations in moist-soil systems. U.S. Department of the Interior, Fish and Wildlife Service. Fish and Wildlife Leaflet 13 in D. Cross and P. Vohs, editors. Waterfowl Management Handbook. Fort Collins, Colorado.

Fredrickson, L. H. and F. A. Reid. 1988a. Invertebrate response to wetland management. .in USFWS, U.S. Department of the Interior, editor. Waterfowl Management Handbook. Fort Collins, Colorado.

Fredrickson, L. H. and F. A. Reid. 1988b. Nutritional values of waterfowl foods. in USFWS, U.S. Department of the Interior, editor. Waterfowl Management Handbook. Fort Collins, Colorado.

Fredrickson, L. H., and M. E. Heitmeyer. 1988. Waterfowl use of forested wetlands of the southern United States: an overview. Pages 307-323 in M. W. Weller, editor. Waterfowl in winter. University of Minnesota Press, Minneapolis, Minnesota, USA.

Fredrickson, L. H., and S. T. Taylor. 1982. Management of seasonally flooded impoundments for wildlife. U.S. Fish and Wildlife Service, Resource Publication 148, Washington, D.C., USA. 
Fretwell, S. D., and H. L. Lucas. 1970. On territorial behavior and other factors influencing habitat distribution in birds. Acta Biotheoretica 19:16-36.

Gawlik, D. E. 2002. The effects of prey availability on the numerical response of wading birds. Ecologiocal Monographs 72:329-346.

Geist, V., S. Mahoney, and J. Organ. 2001. Why hunting has defined the North American model of wildlife conservation. Transactions of the North American Wildlife and Natural Resources Conference 66:175-185.

Grandjean, F., J. Momon, and M. Bramard. 2003. Biological water quality assessment of the Whiteclawed Crayfish habitat based on macroinvertebrate communities: usefulness for its conservation. Bulletin Français de la Pêche et de la Pisciculture 370-371:115-125.

Gray, M. J., R. M. Kaminski, G. Weerakkody, B. D. Leopold, and K. C. Jensen. 1999. Aquatic invertebrate and plant responses following mechanical manipulations of moist-soil habitat. Wildlife Society Bulletin 27:770-779.

Greer, A. K., B. D. Dugger, D. A. Graber, and M. J. Petrie. 2007. The effects of seasonal flooding on seed availability for spring migrating waterfowl. The Journal of Wildlife Management 71:1561-1566.

Greer, D. M., B. D. Dugger, K. J. Reinecke, and M. J. Petrie. 2009. Depletion of rice as food of waterfowl wintering in the Mississippi Alluvial Valley. The Journal of Wildlife Management 73:1125-1133.

Gurd, D. B. 2006. Filter-feeding dabbling ducks (Anas spp.) can actively select particles by size. Zoology 109:120-126.

Hagy, H. M. 2010. Winter foods and waterfowl dynamics in managed moist-soil wetlands in the Mississippi Alluvial Valley. Dissertation, Mississippi State University, Starkville, Mississippi, USA.

Hagy, H. M., J. N. Straub, and R. M. Kaminski. 2011. Estimation and correction of seed recovery bias from moist-soil cores. The Journal of Wildlife Management 75:959966.

Hagy H. M., Kaminski R. M., 2012a. Winter waterbird and food dynamics in autumnmanaged moist-soil wetlands in the Mississippi Alluvial Valley. Wildlife Society Bulletin 36:512-523.

Hagy H. M., Kaminski R. M., 2012b. Apparent seed use by ducks in moist-soil wetlands the Mississippi Alluvial Valley. Journal of Wildlife Management 76:1053-1061.

Hamer, G. L., E. J. Heske, J. D. Brawn, and P. W. Brown. 2006. Migrant shorebird predation on benthic invertebrates along the Illinois river, Illinois. The Wilson Journal of Ornithology 188:152-163. 
Heitmeyer, M. E. 2006. The importance of winter floods to mallards in the Mississippi Alluvial Valley. Journal of Wildlife Management 70:101-110.

Helmers, D. L. 1992. Shorebird management manual. Western Hemisphere Shorebird Reserve Network, Manomet, Massachusetts.

Hepp, G. R. 1985. Effects of environmental parameters on the foraging behavior of three species of wintering dabbling ducks (Anatini). Canadian Journal of Zoology 63:289-294.

Hicks, B. M. 2003. Habitat contribution and waterbird use of Wetland Reserve Program sites in the Cache River watershed, Illinois. Dissertation, Southern Illinois University Carbondale.

Holsman, R. H. 2000. Goodwill hunting? Exploring the role of hunters as ecosystem stewards. Wildlife Society Bulletin 28:808-816.

Huryn, A. C. and J. B. Wallace. 2000. Life history and production of stream insects. Annual Review of Entomology 45:83-110.

Integrated Waterbird Management and Monitoring Program [IWMM]. 2010. Integrated waterbird management and monitoring program of the Atlantic and Mississippi Flyways, habitat quality sub-team, waterfowl workshop summary proposal. Laurel, Maryland: Patuxent Wildlife Research Center.

Isola, C., M. Colwell, O. Taft, and R. Safran. 2000. Interspecific differences in habitat use of shorebirds and waterfowl foraging in managed wetlands of California's San Joaquin Valley. Waterbirds 23:196-203.

Johnson, M. D. 2007. Measuring habitat quality: a review. The Condor 109:489-504.

Kaminski, R. M., G. A. Baldassarre, and A. T. Pearse. 2006. Waterbird responses to hydrological management of Wetlands Reserve Program habitats in New York. Wildlife Society Bulletin 34:921-926.

Kaminski, R. M. and H. H. Prince. 1981. Dabbling duck and aquatic macroinvertebrate responses to manipulated wetland habitat. The Journal of Wildlife Management 45:1-15.

King, S. L. and B. D. Keeland. 1999. Evaluation of reforestation in the Lower Mississippi River Alluvial Valley. Restoration Ecology 7:348-359.

King, S. L., D. J. Twedt, and R. R. Wilson. 2006. The role of the wetland reserve program in conservation efforts in the Mississippi Alluvial Valley. The Wildlife Society Bulletin 34:914-920.

Kostecke, R. M., L. M. Smith, and H. M. Hands. 2005. Macroinvertebrate response to cattail management at Cheyenne Bottoms, Kansas, USA. Wetlands 25:758-763. 
Krapu, G. L. and K. J. Reinecke. 1992. Foraging ecology and nutrition. Pages 1-29 Ecology and Management of Breeding Waterfowl. University of Minnesota Press, Minneapolis, MN, USA.

Laubhan, M. K. 1992. A technique for estimating seed production of common moist-soil plants. U.S. Fish and Wildlife Service Leaflet 13.

Laubhan, M. K. and L. H. Fredrickson. 1992. Estimating seed production of common plants in seasonally flooded wetlands. The Journal of Wildlife Management $56: 329-337$

Laux, J. W. 2008. Waterbird responses to drawdown of two east Tennessee River Valley reservoirs. Thesis, University of Tennessee-Knoxville, Knoxville, Tennessee, USA.

Loesch, C. R., D. J. Twedt, K. Tripp, W. C. Hunter, and M. S. Woodrey. 2000. Development of objectives for waterfowl and shorebirds in the Mississippi alluvial valley. Pages 8-11 in USDA Forest Service Proceedings RMRS-P-16.

Loesch, C. R., K. J. Reinecke, and C. K. Baxter. 1994. Lower Mississippi Valley Joint Venture evaluation plan. North American Waterfowl Management Plan, Vicksburg, Mississippi, USA.

Metcalfe, N. B. 1984. The effects of habitat on the vigilance of shorebirds: is visibility important? Animal Behaviour 32:981-985.

Miller, M. R. 1987. Fall and winter foods of northern pintails in the Sacramento Valley, California. The Journal of Wildlife Management 51:405-414.

Morris, D. W. and S. Mukherjee. 2007. Can we measure carrying capacity with foraging behavior? Ecology 88:597-604.

Murkin, H. R. and D. A. Wrubleski. 1988. Aquatic invertebrates of freshwater wetlands: function and ecology in Ecology and management of wetlands. Croom Helm, London, England.

Murkin, H. R., R. M. Kaminski, and R. D. Titman. 1982. Responses by dabbling ducks and aquatic invertebrates to an experimentally manipulated cattail marsh. Canadian Journal of Zoology 60:2324-2332.

Meyer, C. K., S. D. Peterson, and M. R. Whiles. 2011. Quantitative assessment of yield, precision, and cost-effectiveness of three wetland invertebrate sampling techniques. Wetlands 31:101-112.

Nelms KD. 2007. Wetland management for waterfowl: a handbook. Stoneville, Mississippi: Mississippi River Trust. Available: http://www.ms.nrcs.usda.gov/technical/NRCS\%20Wetland\%20Mgt $\% 20$ for $\% 20 \mathrm{~W}$ aterfowl.pdf. (March 2013). 
Nelson, J. W., and J. A. Kadlec. 1984. A conceptual approach to relating habitat structure and macroinvertebrate production in freshwater wetlands. Transactions of the North America Wildlife and Natural Resources Conference 49:262-270.

Natural Resources Conservation Service. 2013a. Migratory Bird Habitat Initiative. https://prod.nrcs.usda.gov/wps/portal/nrcs/detailfull/national/programs/farmbill/in itiatives/?cid=steldevb1027669/ Accessed 2013 June 27.

Natural Resources Conservation Service. 2013b. Wetlands Reserve Program. http://www.nrcs.usda.gov/wps/portal/nrcs/main/national/programs/easements/wetl ands/ Accessed 2013 June 27.

National Oceanic and Atmospheric Administration (NOAA). 2012. "Climate Prediction Center - Monitoring \& Data: Drought Monitoring." http://www.cpc.ncep.noaa.gov/products/monitoring_and_data/drought.shtml. Accessed 2013 July 08.

Nolet, B. A., O. Langevoord, R. M. Bevan, K. R. Engelaar, M. Klaassen, R. J. Mulder, and S. Van Dijk. 2001. Spatial variation in tuber depletion by swans explained by differences in net intake rates. Ecology 82:1655-1667.

North American Waterfowl Management Plan, Plan Committee. 1986. North American Waterfowl Management Plan: A strategy for conservation. Canadian Wildlife Service, U.S. Fish and Wildlife Service, Secretaria de Medio Ambiente y Recursos Naturales, 106 pp.

North American Waterfowl Management Plan, Plan Committee. 2012. North American Waterfowl Management Plan. People Conserving Waterfowl and Wetlands. Canadian Wildlife Service, U.S. Fish and Wildlife Service, Secretaria de Medio Ambiente y Recursos Naturales, 48 pp.

Olmstead, V. G. 2010. Evaluation of management strategies on moist-soil seed availability and depletion on Wetland Reserve Program sites in the Mississippi Alluvial Valley. Thesis, Arkansas Tech University, Russellville, USA.

Olmstead, V. G., E. B. Webb, and R. W. Johnson. 2013. Moist-Soil Seed Biomass and Species Richness on Wetland Reserve Program Easements in the Mississippi Alluvial Valley. Wetlands 33:1-10.

Olson, E. J., E. S. Engstrom, M. R. Doeringsfeld, and R. Bellig. 1995. Abundance and distribution of macroinvertebrates in relation to macrophyte communities in a prairie marsh, Swan Lake, Minnesota. Journal of Freshwater Ecology 10:325-335.

Percival, S., W. Sutherland, and P. Evans. 1998. Intertidal habitat loss and wildfowl numbers: applications of a spatial depletion model. Journal of Applied Ecology 35:57-63. 
Ratti, J. T. and E. O. Garton. 1994. Research and experimental design. Pages 1-23 in T. A. Bookhout, editor. Research and management techniques for wildlife and habitats. Fifth edition. The Wildlife Society, Bethesda, Maryland, USA.

Reinecke, K. and C. Loesch. 1996. Integrating research and management to conserve wildfowl (Anatidae) and wetlands in the Mississippi Alluvial Valley, USA. Gibier Faune Sauvage 13:927-940.

Reinecke, K. J., and R. M. Kaminski. 2007. Lower Mississippi Valley Joint Venture, waterfowl working group memorandum. U.S. Fish and Wildlife Service, Vicksburg, Mississippi, USA.

Reinecke, K. J., R. M. Kaminski, D. J. Moorehead, J. D. Hodges, and J. R. Nassar. 1989. Mississippi Alluvial Valley. Pages 203-247 in L. M. Smith, R. L. Pederson, and R. M. Kaminski, editors. Habitat management for migrating and wintering waterfowl in North America. Texas Tech University Press, Lubbock, USA.

Reinecke, K. J. and K. M. Hartke. 2005. Research Notes: Estimating Moist-soil Seeds Available to Waterfowl with Double Sampling for Stratification. Journal of Wildlife Management 69:794-799.

Reinecke, R. M., and W. B. Uihlein. 2006. Lower Mississippi Valley Joint Venture, waterfowl working group memorandum. U.S. Fish and Wildlife Service, Vicksburg, Mississippi, USA.

Sanchez, J. and J. Burger. 1999. Perceptions of on-site hunters: Environmental concerns, future land use, and cleanup options at the Savannah River Site. Journal of Toxicology and Environmental Health Part A 57:267-281.

SAS Institute, Inc. 2012. SAS® 9.2, Enhanced Logging Facilities, Cary, North Carolina, USA.

Scheaffer, R. L., W. Mendenhall, and R. L. Ott. 2006. Elementary survey sampling. Sixth ed. Duxbury Press, Boston Mass. 464pp.

Sherfy, M. H., R. L. Kirkpatrick, and K. D. Richkus. 2000. Benthos core sampling and chironomid vertical distribution: implications for assessing shorebird food availability. Wildlife Society Bulletin 28:124-130.

Skagen, S. K., D. A. Granfors, and C. P. Melcher. 2008. On determining the significance of ephemeral continental wetlands to North American migratory shorebirds. Auk 125:20-29.

Skagen, S. K. and F. L. Knopf. 1993. Toward Conservation of Midcontinental Shorebird Migrations. Conservation Biology 7:533-541.

Skagen, S. K. and F. L. Knopf. 1994. Migrating shorebirds and habitat dynamics at a prairie wetland complex. The Wilson Bulletin 106:91-105. 
Skagen, S. K. and H. D. Oman. 1996. Dietary flexibility of shorebirds in the western hemisphere. Canadian Field-Naturalist 110:419-444.

Smith, L. M., D. A. Haukos, and R. M. Prather. 2004. Avian response to vegetative pattern in playa wetlands during winter. Wildlife Society Bulletin 32:474-480.

Stafford, J. D., R. M. Kaminski, K. J. Reinecke, and S. W. Manley. 2006. Waste rice for waterfowl in the Mississippi Alluvial Valley. Journal of Wildlife Management 70:61-69.

Stagliano, D. M. and M. R. Whiles. 2011. Macroinvertebrate production and trophic structure in a tallgrass prairie headwater stream. Journal of the North American Benthological Society 21:97-113.

Straub, J. N. 2008. Energetic carrying capacity of habitats used by spring migrating waterfowl in the Upper Mississippi and Great Lakes Region during spring migration. Thesis, The Ohio State University, Columbus, USA.

Straub, J. N., R. J. Gates, R. D. Schultheis, T. Yerkes, J. M. Coluccy, and J. D. Stafford. 2012. Wetland food resources for spring-migrating ducks in the Upper Mississippi River and Great Lakes Region. The Journal of Wildlife Management 76:768-777.

Smith, L. M., D. A. Haukos, and R. M. Prather. 2004. Avian response to vegetative pattern in playa wetlands during winter. Wildlife Society Bulletin 32:474-480.

Smith, L. M. and D. G. Sheeley. 1993. Factors affecting condition of northern pintails wintering in the Southern High Plains. The Journal of Wildlife Management 57:62-71.

Twedt, D. J. and C. O. Nelms. 1999. Waterfowl density on agricultural fields managed to retain water in winter. Wildlife Society Bulletin 27:924-930.

Twedt, J. D., C. O. Nelms, V. E. Rettig, and S. R. Aycock. 1998. Shorebird use of managed wetlands in the Mississippi Alluvial Valley. The American Midland Naturalist 140:140-152.

Van Gils, J. A., P. Edelaar, G. Escudero, and T. Piersma. 2004. Carrying capacity models should not use fixed prey density thresholds: a plea for using more tools of behavioural ecology. Oikos 104:197-204.

Voigts, D. K. 1976. Aquatic invertebrate abundance in relation to changing marsh vegetation. American Midland Naturalist 95:313-322.

Webb, E. B., L. M. Smith, M. P. Vrtiska, and T. G. Lagrange. 2010. Effects of local and landscape variables on wetland bird habitat use during migration through the Rainwater Basin. The Journal of Wildlife Management 74:109-119. 
Wehrle, B. W., R. M. Kaminski, B. D. Leopold, and W. P. Smith. 1995. Aquatic invertebrate resources in Mississippi forested wetlands during winter. Wildlife Society Bulletin 23:774-783.

Weller, M. W. and C. S. Spatcher. 1965. Role of habitat in the distribution and abundance of marsh birds. Agricultural and Home Economic Experiment Station, Iowa State University of Science and Technology, Ames, Iowa, USA. Special Report 43.

Whiting, D. P., M. R. Whiles, and M. L. Stone. 2011. Patterns of macroinvertebrate production, trophic structure, and energy flow along a tallgrass prairie stream continuum. Limnology and Oceanography 56:887-898.

Wiens, J. A. 1989. Spatial scaling in ecology. Functional ecology 3:385-397.

Wirwa, D. W. 2009. Waterbird use of Kentucky reservoir mudflats. Thesis, University of Tennessee-Knoxville, Knoxville, Tennessee, USA.

Zar, J. H. 1999. Biostatistical analysis. Prentice Hall, Upper Saddle River, New Jersey, USA. 
Table 1.1. Recent (1-2 years) management histories of Wetland Reserve Program (WRP) sites in Arkansas and Missouri, a subset of which was enrolled in the Migratory Bird Habitat Initiative (MBHI) during summer 2010, which provided additional technical and financial support to landowners to implement moist-soil management practices on their easements.

\begin{tabular}{|c|c|c|c|c|c|c|}
\hline State & Site & Contract & $\begin{array}{l}\text { Mowing/ } \\
\text { Disking }\end{array}$ & Planting & $\begin{array}{c}\text { Active } \\
\text { Inundation }\end{array}$ & $\begin{array}{l}\text { WRP contract } \\
\text { duration }^{1}(\mathrm{yrs})\end{array}$ \\
\hline AR & BLA* & MBHI WRP & $\bullet$ & - & $\bullet$ & $0-10 \mathrm{yrs}$ \\
\hline AR & CAL* & MBHI WRP & & $\bullet$ & & $0-10 \mathrm{yrs}$ \\
\hline MO & CAT & MBHI WRP & $\bullet$ & $\bullet$ & $\bullet$ & $10-20 \mathrm{yrs}$ \\
\hline MO & CAV & MBHI WRP & $\bullet$ & $\bullet$ & $\bullet$ & $0-10 \mathrm{yrs}$ \\
\hline AR & CGJ & MBHI WRP & $\bullet$ & $\bullet$ & $\bullet$ & $0-10 \mathrm{yrs}$ \\
\hline MO & $\mathrm{CRI}^{*}$ & MBHI WRP & $\bullet$ & $\bullet$ & $\bullet$ & $10-20 \mathrm{yrs}$ \\
\hline AR & DUT & MBHI WRP & $\bullet$ & & & $10-20 \mathrm{yrs}$ \\
\hline AR & GOL & MBHI WRP & $\bullet$ & & & $10-20 \mathrm{yrs}$ \\
\hline MO & HAS* & MBHI WRP & $\bullet$ & $\bullet$ & $\bullet$ & $0-10 \mathrm{yrs}$ \\
\hline $\mathrm{AR}$ & ICE* & MBHI WRP & $\bullet$ & $\bullet$ & $\bullet$ & $10-20 \mathrm{yrs}$ \\
\hline MO & MIN* & MBHI WRP & $\bullet$ & $\bullet$ & $\bullet$ & $0-10 \mathrm{yrs}$ \\
\hline MO & MIT & MBHI WRP & $\bullet$ & $\bullet$ & $\bullet$ & $10-20 \mathrm{yrs}$ \\
\hline AR & PLU & MBHI WRP & $\bullet$ & $\bullet$ & $\bullet$ & $10-20 \mathrm{yrs}$ \\
\hline AR & QUA & MBHI WRP & & & & $10-20 \mathrm{yrs}$ \\
\hline AR & ALL* & WRP only & & & $\bullet$ & $10-20 \mathrm{yrs}$ \\
\hline MO & BAS & WRP only & $\bullet$ & - & & $0-10 \mathrm{yrs}$ \\
\hline MO & BAT & WRP only & & & & $0-10 \mathrm{yrs}$ \\
\hline AR & CGR & WRP only & $\bullet$ & $\bullet$ & $\bullet$ & $0-10 \mathrm{yrs}$ \\
\hline MO & COR & WRP only & $\bullet$ & $\bullet$ & $\bullet$ & $0-10 \mathrm{yrs}$ \\
\hline MO & CUR* & WRP only & & & & $0-10 \mathrm{yrs}$ \\
\hline AR & DEN* & WRP only & & & & $0-10 \mathrm{yrs}$ \\
\hline AR & FUL* & WRP only & $\bullet$ & $\bullet$ & $\bullet$ & $0-10 \mathrm{yrs}$ \\
\hline AR & JAR & WRP only & & & & $0-10 \mathrm{yrs}$ \\
\hline MO & LEM & WRP only & $\bullet$ & • & $\bullet$ & $0-10 \mathrm{yrs}$ \\
\hline MO & WAL* & WRP only & $\bullet$ & & & $0-10 \mathrm{yrs}$ \\
\hline AR & WOU* & WRP only & & & & $0-10 \mathrm{yrs}$ \\
\hline
\end{tabular}

*Subsampled wetlands chosen for invertebrate sampling

1 Time since initial WRP enrollment 
Table 1.2. Mean $(\overline{\boldsymbol{x}} \pm \mathrm{SE})$ waterbird densities (birds/ha) and species richness (species/ha) at Migratory Bird Habitat Initiative (MBHI) wetlands ( $n=12$ wetlands), Wetland Reserve Program (WRP) wetlands ( $n=12$ wetlands), and publicly owned wetlands ( $n=6$ wetlands) wetlands in Arkansas and Missouri during autumn 2011.

\begin{tabular}{lrrr}
\hline & \multicolumn{3}{c}{ Wetland Type } \\
\cline { 2 - 4 } & $\begin{array}{r}\text { MBHI } \\
(n=36 \text { surveys })\end{array}$ & $\begin{array}{r}\text { WRP } \\
(n=33 \text { surveys })\end{array}$ & $\begin{array}{r}\text { Public } \\
\text { Densities (birds/ha) }\end{array}$ \\
Shorebirds & $3.08 \pm 1.34$ & $1.56 \pm 1.36$ & $2.18 \pm 1.55$ \\
All waterbirds & $4.24 \pm 1.49$ & $2.57 \pm 1.52$ & $3.49 \pm 1.78$ \\
\hline Species Richness (species/ha) & & & \\
Shorebirds & $2.03 \pm 1.18$ & $1.19 \pm 1.19$ & $1.40 \pm 1.40$ \\
All waterbirds & $2.59 \pm 1.23$ & $1.40 \pm 1.24$ & $1.76 \pm 1.76$ \\
\hline
\end{tabular}


Table 1.3. Mean $(\overline{\boldsymbol{x}} \pm \mathrm{SE}$ ) waterfowl densities (birds/ha) and species richness (species/ha) at Migratory Bird Habitat Initiative (MBHI) wetlands ( $n=13$ wetlands), Wetland Reserve Program (WRP) wetlands ( $n=12$ wetlands), and publicly owned wetlands ( $n=7$ wetlands) wetlands in Arkansas and Missouri during autumn 2011.

\begin{tabular}{lrrr}
\hline & \multicolumn{3}{c}{ Wetland Type } \\
\cline { 2 - 4 } & MBHI & WRP & $\begin{array}{r}\text { Public } \\
\text { Densities (birds/ha) }\end{array}$ \\
Dabbling ducks & $2.89 \pm 1.23$ & $1.37 \pm 1.24$ & $1.82 \pm 1.33$ \\
All waterfowl & $3.19 \pm 1.24$ & $1.43 \pm 1.25$ & $1.94 \pm 1.34$ \\
\hline Species Richness (species/ha) & & & \\
Dabbling ducks & $1.40 \pm 1.06$ & $1.14 \pm 1.06$ & $1.14 \pm 1.08$ \\
All waterfowl & $1.49 \pm 1.06$ & $1.17 \pm 1.06$ & $1.20 \pm 1.09$ \\
\hline
\end{tabular}




\section{Wetland Locations in AR and MO}

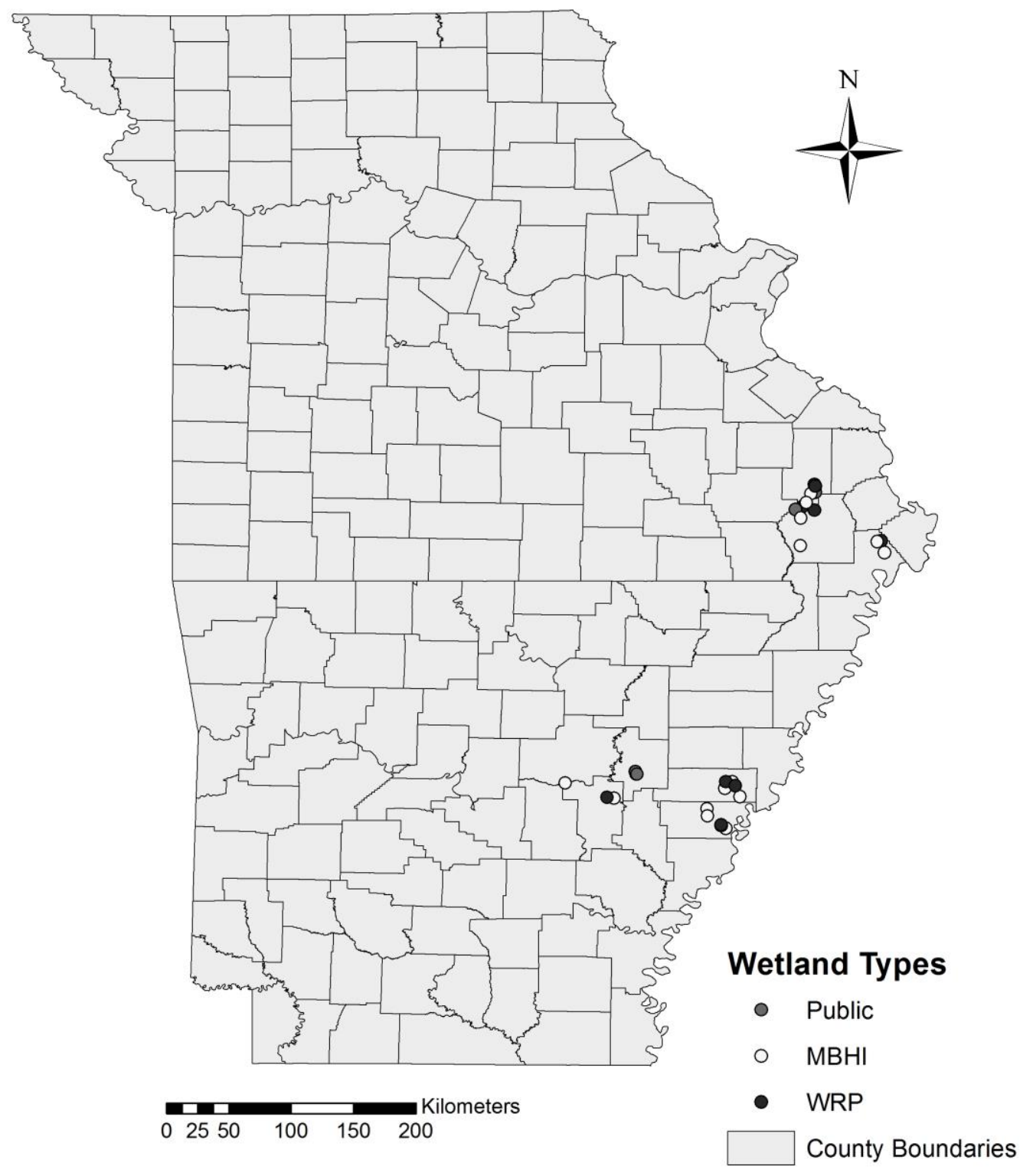

Figure 1.1. Locations of Arkansas and Missouri study wetlands within Wetland Reserve Program (WRP) easements, WRP wetlands enrolled in the Migratory Bird Habitat Initiative (MBHI), and public managed wetlands used to assess effects of moist-soil 
management on migratory waterbird use and food availability during autumn 2011 and winter 2011-2012.
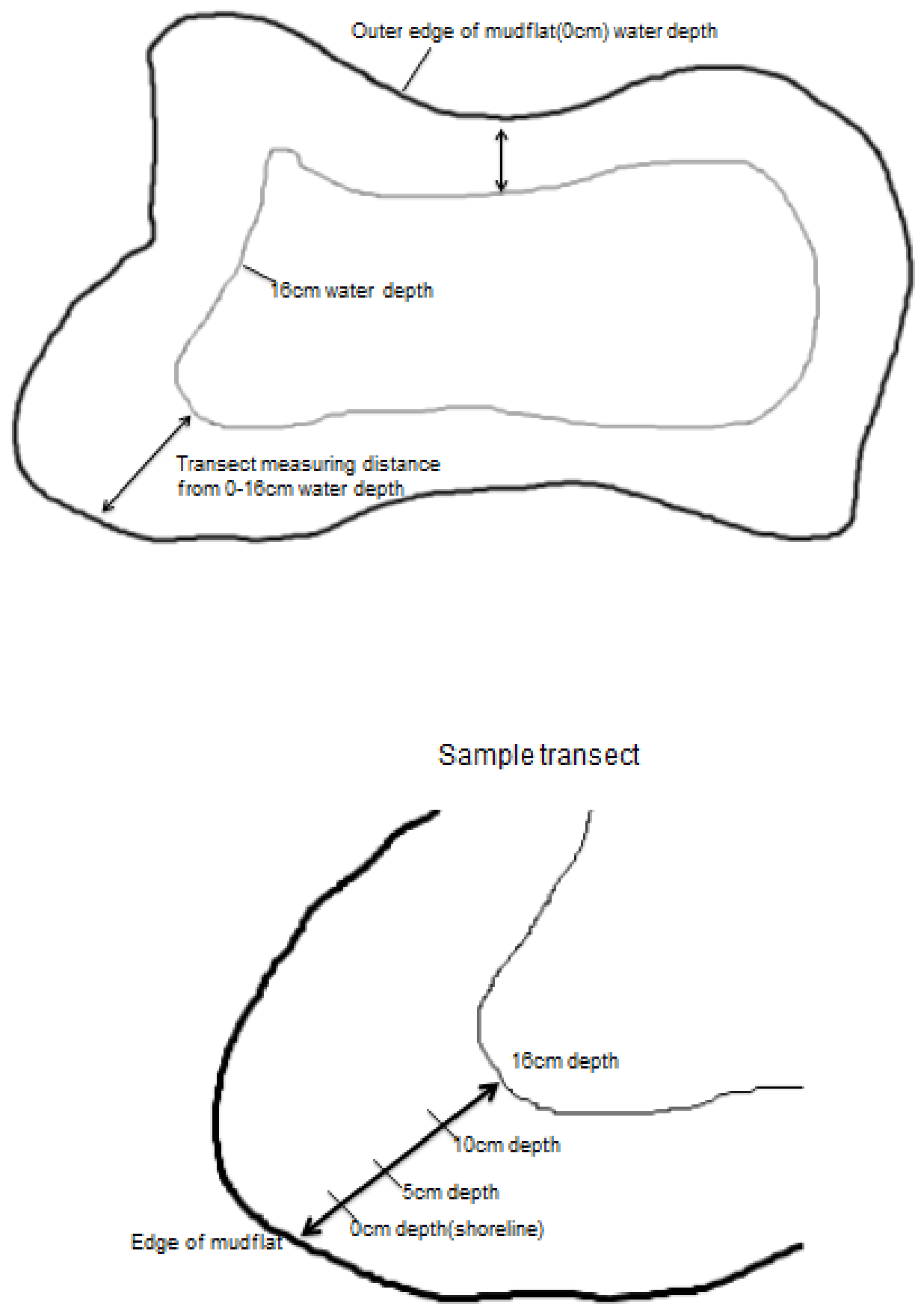
Figure 1.2. Examples illustrating autumn 2011 shorebird habitat sample transects and designated water depth strata within a wetland.

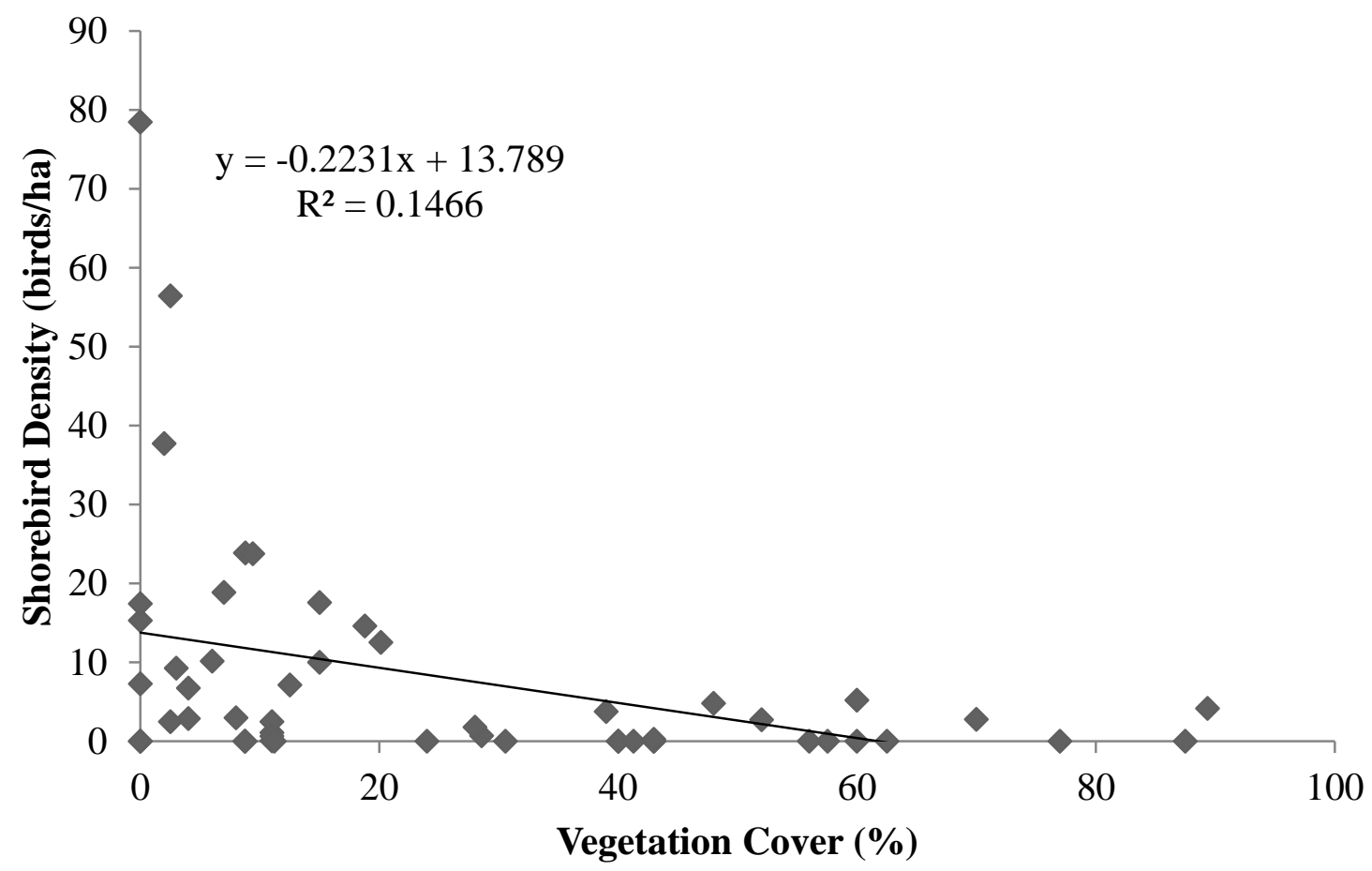

Figure 1.3. Relationship between autumn bi-weekly shorebird densities and observed vegetation cover at Wetland Reserve Program, Migratory Bird Habitat Initiative, and Public wetlands ( $n=29)$ in Arkansas and Missouri during autumn 2011. 


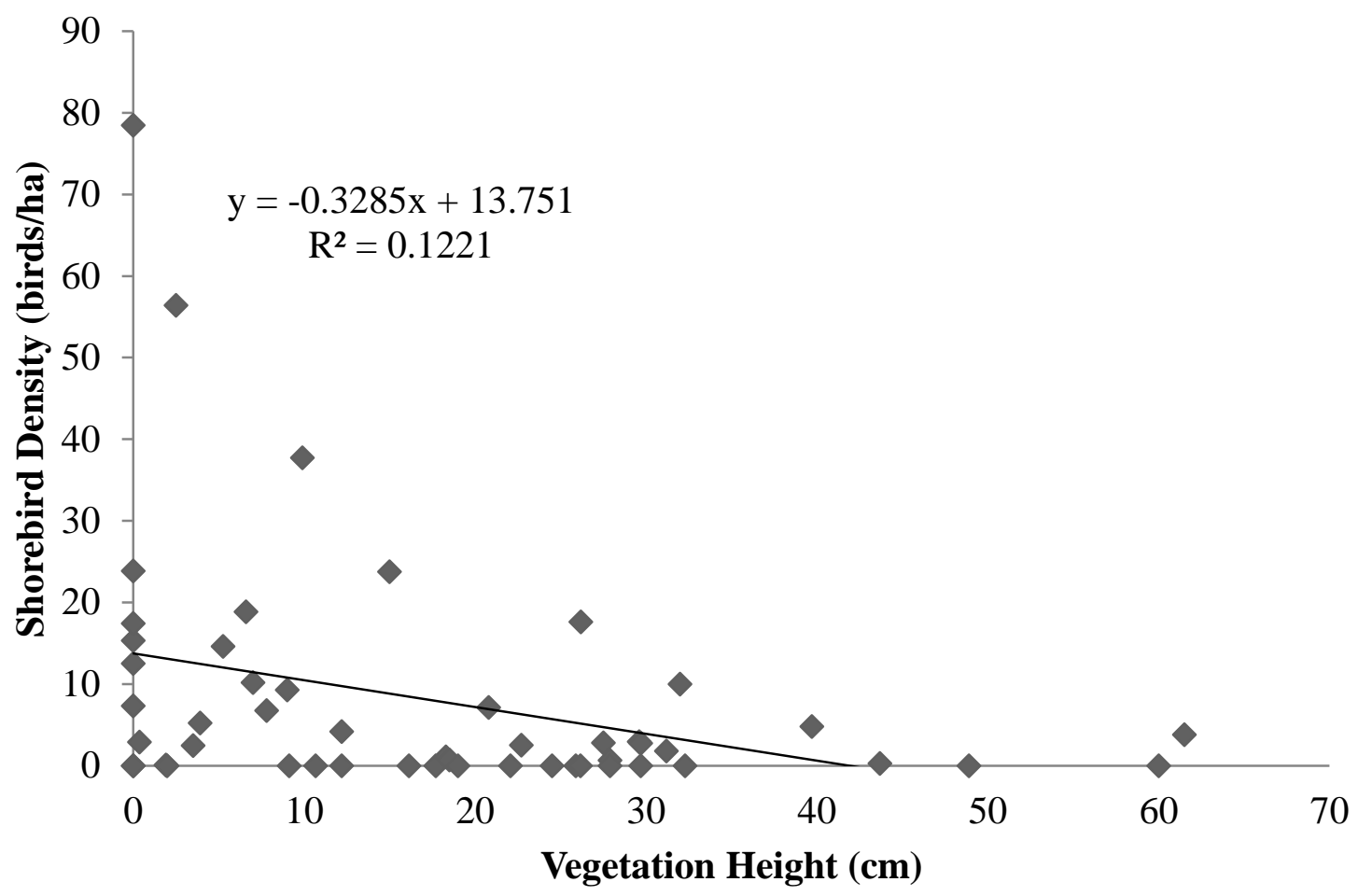

Figure 1.4. Relationship between autumn bi-weekly shorebird densities and observed vegetation height at Wetland Reserve Program, Migratory Bird Habitat Initiative, and Public wetlands $(n=29)$ in Arkansas and Missouri during autumn 2011. 


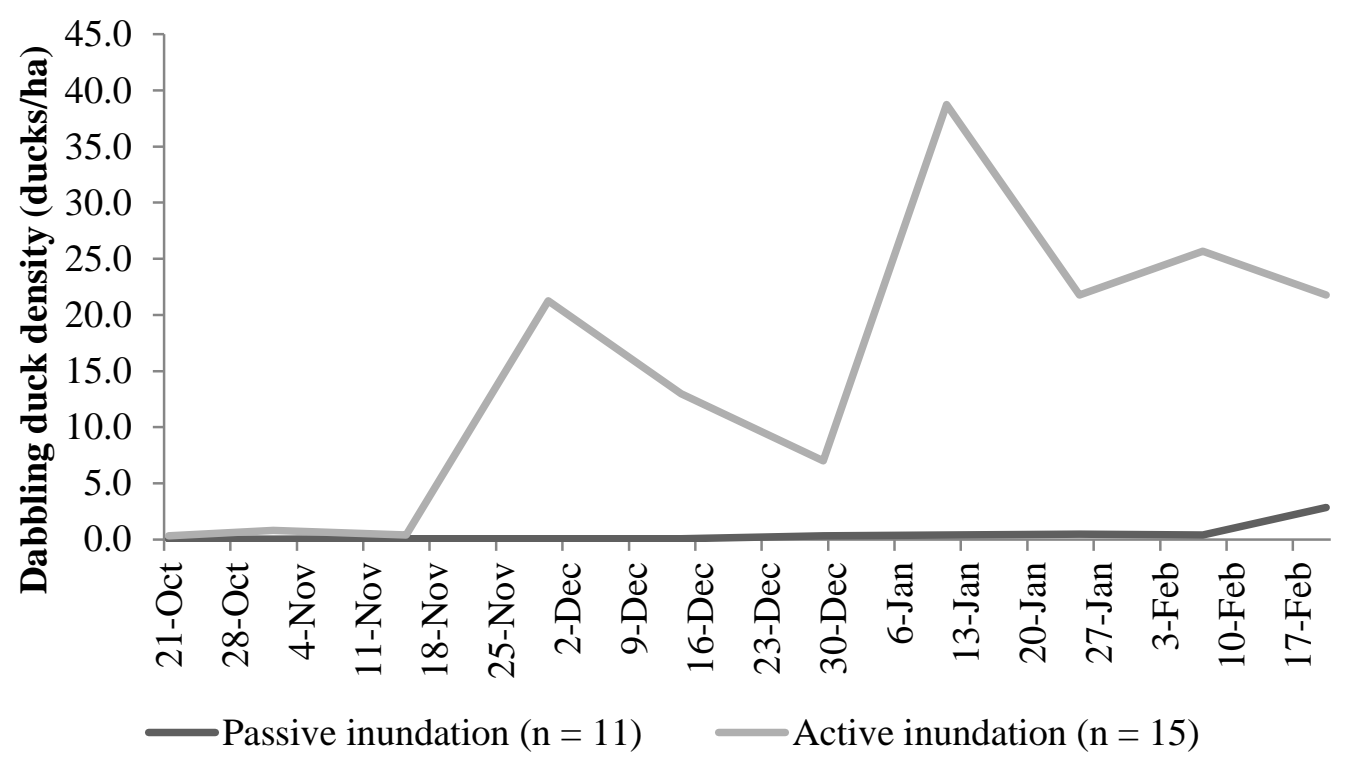

Figure 1.5. Mean dabbling duck densities observed at all private wetlands (Wetland Reserve Program and Migratory Bird Habitat Initiative) in Arkansas and Missouri with active and passive inundation strategies from October 2012 - February 2012. 


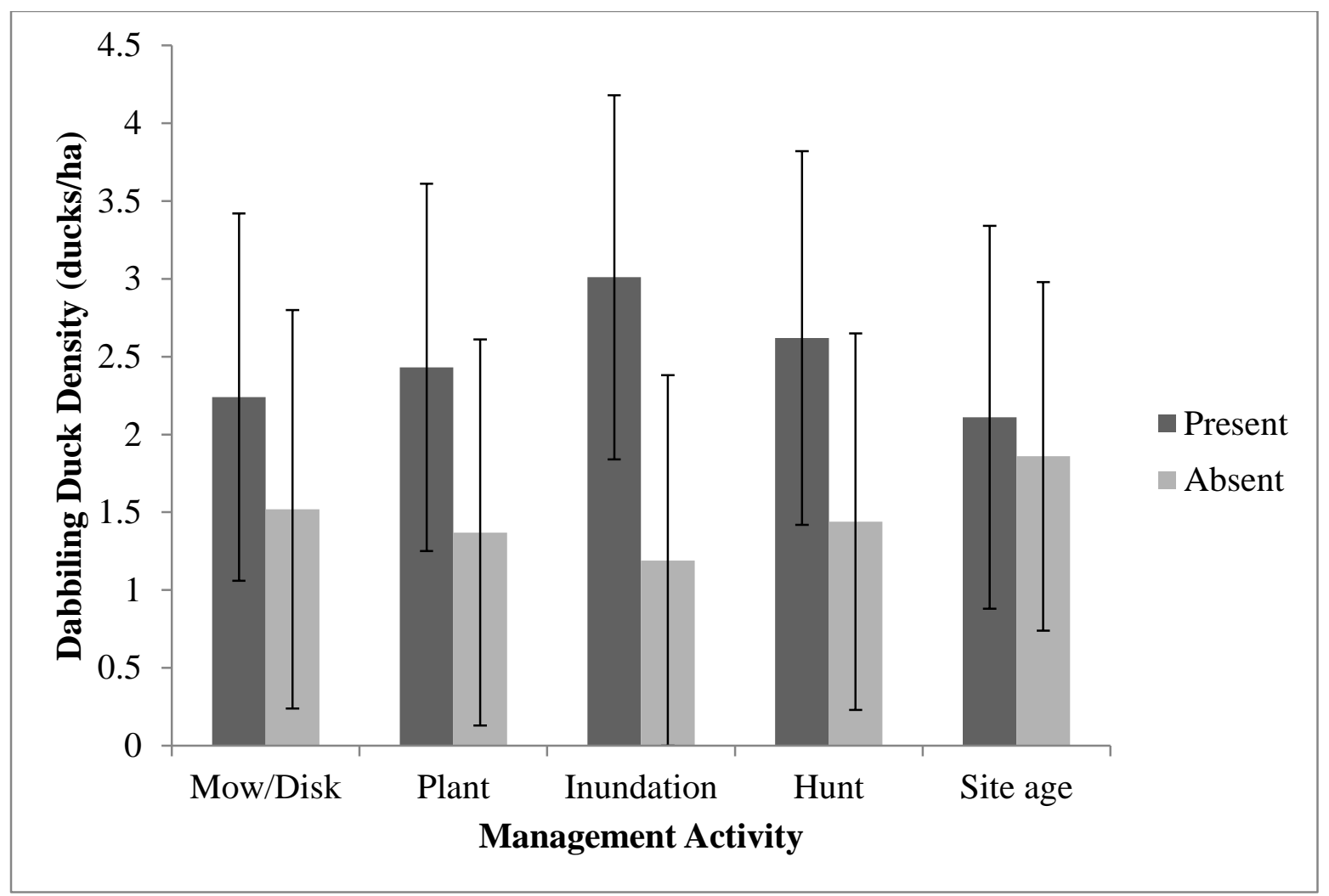

Figure 1.6. Mean dabbling duck densities at private wetlands (Wetland Reserve Program and Migratory Bird Habitat Initiative) displayed by wetland management practices and other site characteristics in Arkansas and Missouri during winter 2011-2012. For mow/disk, plant, inundation and hunt categories, "present" indicates that the activity occurred at the wetland in 2011. Site age is a wetland variable for which "present" indicates initial enrollment in WRP and restoration occurred 0-10 years previously, and "absent" indicates restoration and enrollment 10-20 years previously. 


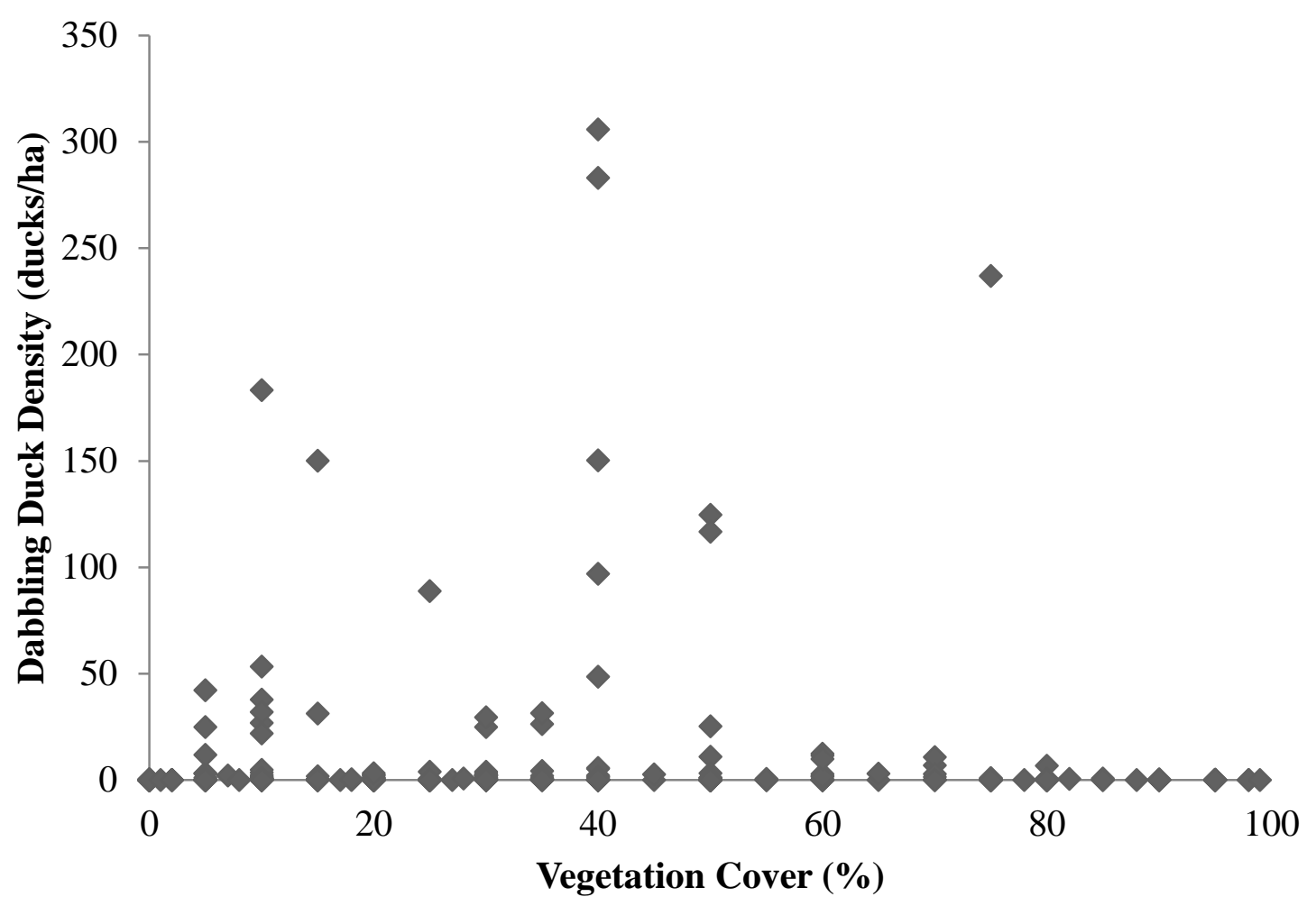

Figure 1.7. Relationship between bi-weekly dabbling duck densities and observed vegetation cover at Wetland Reserve Program, Migratory Bird Habitat Initiative, and Public wetlands ( $n=33)$ in Arkansas and Missouri during winter 2011-2012. 


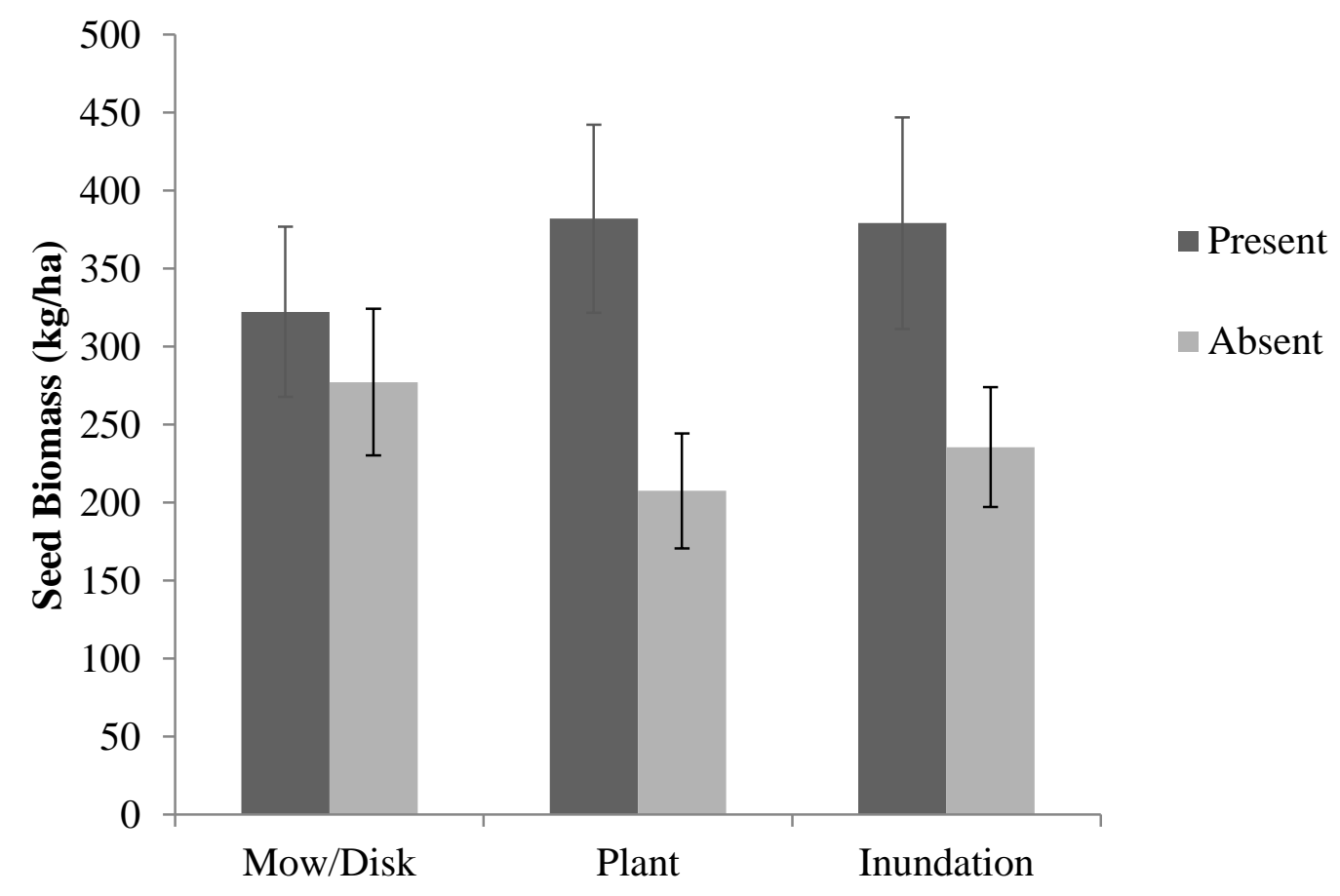

Figure 1.8. Initial seed biomass at private wetlands (Wetland Reserve Program and Migratory Bird Habitat Initiative) displayed by wetland management practices in Arkansas and Missouri during October 2011. For mow/disk, plant, and inundation categories, "present" indicates that the activity occurred at the wetland in 2011. 


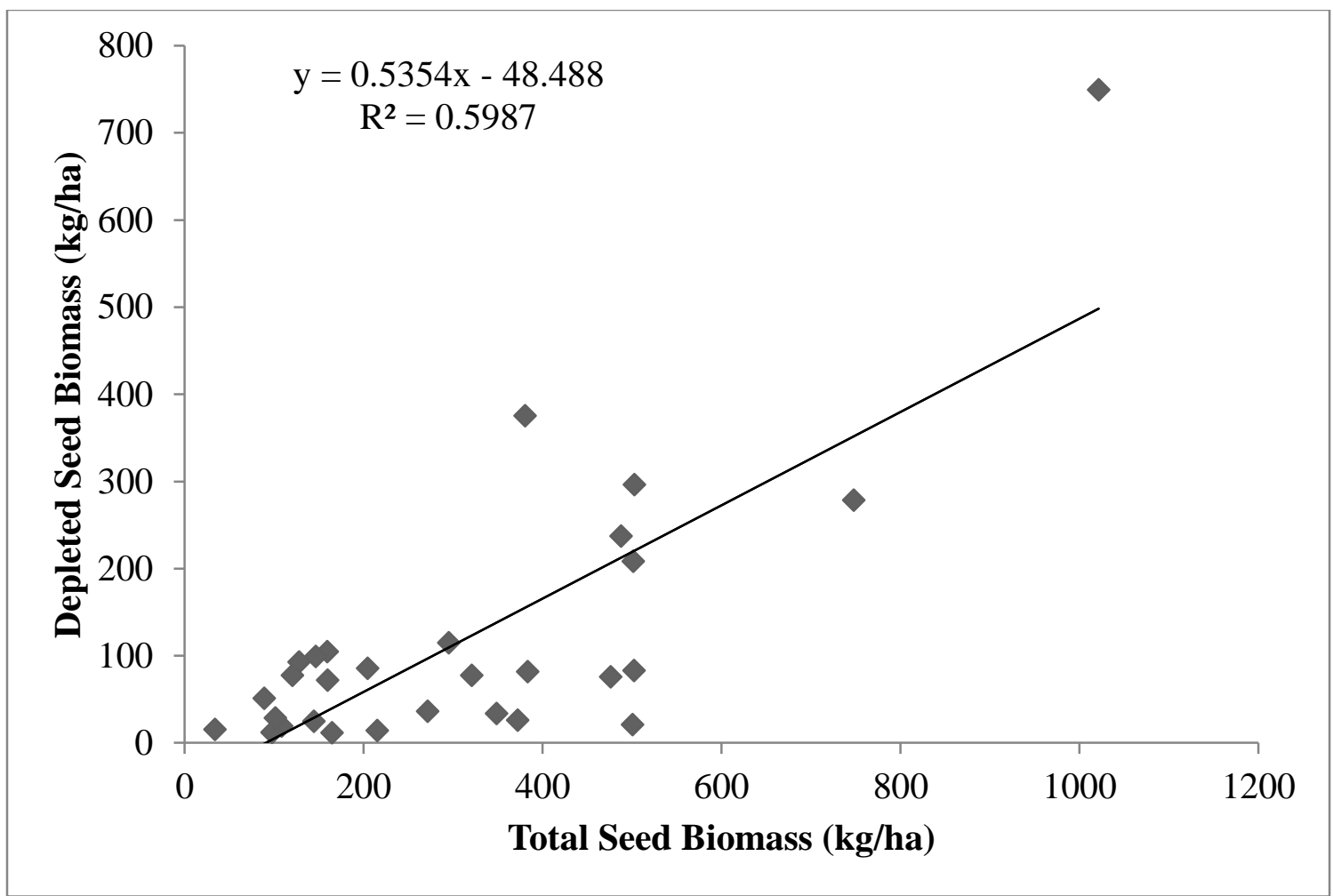

Figure 1.9. Relationship between initial seed biomass and total seed depletion at Wetland Reserve Program, Migratory Bird Habitat Initiative, and Public wetlands $(n=29)$ in Arkansas and Missouri during winter 2011-2012. 


\section{CHAPTER II:}

\section{EFFECTS OF MANAGEMENT ON AQUATIC INVERTEBRATE BIOMASS, PRODUCTION, AND COMMUNITY COMPOSITION AT WETLAND RESERVE PROGRAM SITES IN THE LOWER MISSISSIPPI ALLUVIAL VALLEY}

Food availability has long been identified as a limiting factor for migratory waterbirds in nonbreeding habitats (Heitmeyer and Fredrickson 1981, Richardson and Kaminski 1992, Drent et al. 2006, Newton 2006). Wetland managers often use a variety of techniques to sustain early successional wetland plant communities in seasonal wetlands that are capable of producing high volumes of seeds often consumed by waterfowl (Haukos and Smith 1993, Anderson and Smith 1998). Estimates of moist-soil seed biomass and total metabolizable energy are often used to calculate the potential number of ducks that can be maintained on a wetland for a period of time, also known as energetic carrying capacity or duck-energy days (Haukos and Smith 1993, Kaminski et al. 2003; Kross et al. 2008, Hagy and Kaminski 2012). Dabbling ducks, among other waterbird groups including shorebirds and wading birds, also consume invertebrates (Fredrickson and Taylor 1982). While many studies have evaluated the effects of moistsoil management on invertebrate biomass and community composition, invertebrate secondary production is a response variable that has rarely been evaluated (Batzer and Resh 1992, de Szalay and Resh 1997, Gray et al. 1999, Kostecke et al. 2005, Hagy and Kaminski 2012). However, there is mounting evidence that the dynamics of aquatic invertebrate populations in seasonal wetlands are a vital element to consider when determining the implications of wetland management for migrating and wintering 
waterbirds (Benke 1984, Duffy and LaBar 1994, Anderson and Smith 2000, Batzer 2013).

Aquatic invertebrates are the major source of protein that enables survival and reproduction for many waterbird species (Krapu and Reinecke 1992, Skagen and Oman 1996, Davis and Smith 1998a, Davis and Bidwell 2008). Dabbling ducks may be forced to delay molt and possibly the timing of other major life events due to a lack of protein availability (i.e. aquatic invertebrates; Swanson and Meyer 1977, Richardson and Kaminski 1992, Anderson et al. 2000). Aquatic invertebrates are the only food source in shorebird (Charadriiformes) diets (Skagan and Oman 1996). Shorebird populations are in decline, with nonbreeding habitat loss being a likely cause (Helmers 1992, Harrington 2003). Therefore, waterbird food approximation studies that include estimates of aquatic invertebrate availability are likely to yield more inclusive management implications for waterbirds (Anderson and Smith 1998).

The importance of invertebrates in waterbird diets has led to various studies of aquatic invertebrate responses to moist-soil management techniques (de Szalay et al. 1996, de Szalay and Resh 1997, Gray et al. 1999, Anderson and Smith 2000, Kostecke et al. 2005). Wetland managers use a combination of management techniques, including soil disturbance (e.g. disking, tilling), planting, and flooding regimes, on seasonally flooded wetlands to increase moist-soil seed production and waterfowl use (Fredrickson and Taylor 1982, Haukos and Smith 1993, Fredrickson 1991, Gray et al. 1999). Managers manipulate water levels to mimic historic seasonal wetland hydrology through spring or summer drawdowns, which facilitates growth of hydrophytes and decomposition of organic matter (detritus), and autumn or winter flooding to provide 
foraging habitat for wintering dabbling ducks (Fredrickson and Taylor 1982, Reid et al. 1989, Haukos and Smith 1993). Invertebrate abundance can also be positively influenced through active management by increasing vegetative growth and decomposition, providing additional food and habitat structure for invertebrates (Anderson and Smith 2000, Davis and Bidwell 2008, Meyer et al. 2011). Specific wetland management techniques employed on moist-soil habitats can, however, affect total invertebrate biomass and diversity. In one study, autumn mowing of seasonal wetlands resulted in greater invertebrate biomass and diversity compared to wetlands that were tilled and disked (Gray et al. 1999).

The occurrence of aquatic invertebrates in seasonal wetlands is generally restricted to species that enter the site as a result of flooding events, adults with wings (non-residents), and species with drought resistant life stages (Wiggins et al. 1980, Euliss and Grodhaus 1987, Williams 1987). Once invertebrates have colonized a wetland, community composition transitions over time as a result of seasonal reproductive patterns, ecological succession, predators, and source of wetland hydrology (e.g., groundwater, river, precipitation, runoff; Butler 1984, Danell and Sjoberg 1982). Most studies are not applicable across geographic locations because of regional variation among environmental factors that can also affect invertebrate populations such as climate, water chemistry, and soil types (Gray et al. 1999, Davis and Bidwell 2008). Nevertheless, biologists can infer a variety of details about wetlands, such as wetland ecosystem health and energy-nutrient availability, by evaluating invertebrate biomass and community composition (Wiggins et al. 1980, Fredrickson and Reid 1988, Grey et al. 1999, Helgen and Gernes 2001, Meyer et al. 2011). For example, Helgen and Gernes 
(2001) observed fewer invertebrate taxa in wetlands that contained chemicals from urban or agricultural runoff, especially among caddisflies (Trichoptera), dragonflies (Odonata), mayflies (Ephemeroptera), fingernail clams (Veneroida), and midges (Diptera). The Ephemeroptera, Trichoptera, and Plecoptera (EPT) index is a metric of familial richness for aquatic invertebrates considered to be sensitive to pollutants and is a relatively simple way to assess wetland ecosystem health (Grandjean et al. 2003).

While a majority of studies have quantified invertebrate biomass and richness as a way of evaluating wetland management techniques, few have considered the importance of invertebrate production within wetlands (Kaminski and Prince 1981, Batzer and Resh 1992, de Szalay and Resh 1997, Gray et al. 1999, Anderson and Smith 2000, Bolduc and Afton 2003, Kostecke et al. 2005, Davis and Bidwell 2008). Secondary production, or the formation of animal biomass through time, is a commonly used metric in studies of freshwater ecosystems, and more specifically, aquatic invertebrate roles within those ecosystems (Benke and Huryn 2010). Estimates of invertebrate secondary production are considered a useful measure of ecological function because they allow researchers to consider abundance, biomass, growth, reproduction, survivorship, and even colonization of different invertebrate taxa and link consumers directly to ecosystem functions and processes such as energy flow and nutrient cycling (Benke and Huryn 2006). However, there is limited information on turnover rates of aquatic invertebrates in wetland ecosystems (Benke 1984, Benke 2010). By using secondary production of aquatic invertebrates to assess wetland management techniques, researchers may be able to more accurately link waterbird use to food abundance throughout the winter season, and help refine habitat management strategies and carrying capacity estimates for migrating 
waterbirds (Anderson and Smith 2002, Bolduc and Afton 2003). Investigators have already connected invertebrate production to variables that are relatively easier to measure, such as invertebrate body size and temperature, and have subsequently derived empirical models to estimate invertebrate production based on length-mass relationships (Benke 1993, Benke and Huryn 2010). The resulting models allow for a less intensive "short-cut" to estimating production (Benke and Huryn 2010). The assessment of other invertebrate metrics, including production, may offer a more comprehensive analysis of invertebrate response to wetland management compared to biomass, which is an estimate of invertebrate presence at a certain point in time (Duffy and LaBar 1994).

Public land managers often have the resources to manipulate several wetland impoundments concurrently, allowing them to manage for the specific habitat and diet requirements of different waterbird groups (Fredrickson 1991). However, considering that approximately $70 \%$ of the land in the Lower 48 states is privately owned, encouragement and evaluation of private land management is critical to meeting regional conservation objectives established by the North American Waterfowl Management Program (Gray and Teels 2006, King et al. 2006). The Wetland Reserve Program (WRP) is a voluntary easement program established by the 1990 Farm Bill and administered by the Natural Resources Conservation Service (NRCS) to restore, enhance and protect wetlands on private properties. Through financial incentives and technical support, private landowners are encouraged to retire farmlands from agricultural production and restore them to their previous hydrology, or to protect and enhance existing wetlands (NRCS 2013b). After initial restoration, WRP participants have no contractual obligation to provide additional management. However, some landowners do engage active 
management practices and can enhance habitat conditions for waterbirds (Evans-Peters et al. 2012, Fleming et al. 2012, Olmstead et al. 2013). The NRCS implemented the Migratory Bird Habitat Initiative (MBHI) in 2010 to mitigate potential loss of wetland habitats resulting from the Deepwater Horizon oil spill (Buler et al 2013). The overall goal of the MBHI was to improve wetlands on private farmlands, catfish ponds, and WRP easements in the Lower Mississippi Alluvial Valley (LMAV) for wintering dabbling ducks and migrating shorebirds. Priorities of the MBHI for WRP easements included improving waterbird food habitats, providing habitat structure, and additional management activities such as planting and/or disking on seasonally flooded shallow wetlands, or moist-soil wetlands. Although WRP easements have been designated as critical wildlife habitat, little research has been conducted to assess the effects of the WRP on aquatic invertebrates in the LMAV (Gray and Teels 2006, King et al. 2006). Understanding the effects of management on waterbird foods on privately managed wetlands is a crucial component to evaluating the current condition of private wetlands, establishing and meeting regional waterbird carrying capacity objectives, and improving current management practices (King et al. 2006, Evans-Peters et al. 2012, Olmstead et al. 2013). The goals of this study were to evaluate the effects of wetland management on invertebrate biomass, production, and community composition at wetlands enrolled in the WRP in the LMAV of Arkansas and Missouri. For comparison, I also evaluated invertebrates at WRP wetlands not enrolled in MBHI (i.e., management is not required) and long-term actively managed public sites (e.g., refuges, conservation areas). Current methods employed for invertebrate sampling and processing are time consuming (Doğramaci et al. 2010), therefore I also explored the possibility of 
developing a rapid assessment technique of wetland invertebrate biomass and production in seasonal wetlands.

\section{Study Area}

Study wetlands were located on private easement lands enrolled in the WRP and actively managed public lands in the LMAV of Arkansas and Missouri. I stratified potential study wetlands by county, identified the 3 counties containing the greatest number of MBHI contracts within each state, and randomly selected individual WRP easements enrolled in the MBHI within these counties (Stafford et al. 2006a, Ratti and Garton 1994). The 3 counties containing the greatest number of MBHI contracts were Lee, Prairie, and St. Francis counties in Arkansas, and Bollinger, Stoddard and New Madrid counties in Missouri. I randomly apportioned $13 \mathrm{MBHI}$ easements among selected Arkansas and Missouri counties (Figure 1.2). Similarly, I selected 12 reference WRP easements (hereafter WRP) in the same counties that received no additional MBHI funding for implementation of active management practices. I obtained contract information from NRCS district conservationists and landowners and if an easement contained more than one wetland, I randomly selected a single wetland within each easement. I also obtained information from landowners on recent management activities (during the past year), as well as the year each wetland was enrolled in the WRP (Table 2). Specific variables recorded were mowing/disking, active inundation, planting, hunting, and time since WRP enrollment (also called "site age"; 0-10 years or 10-20 years). As an additional reference, I selected 7 sites on public lands that represented longterm, intensively managed moist-soil wetlands (Duck Creek Conservation Area [1 site] 
and Mingo National Wildlife Refuge [2 sites] in Missouri; Cache River National Wildlife Refuge [4 sites] in Arkansas).

Area of all private wetlands (MBHI and WRP) ranged from 1.1 - 48.6 ha. Topography, wetland characteristics, and financial resources varied among landowners, which influenced the type and intensity of management techniques. All study wetlands except one (WRP) had a water control structure, which enabled draining or retaining water on wetlands. Area of study wetlands on public lands ranged from $3.4-43.2$ ha. Water sources for study wetlands originated from rivers, ditches, pumps, runoff, and precipitation. No study wetlands had interconnected hydrology; therefore, wetlands were considered discrete, independent survey and analytical units (Fleming et al 2012). Commonly occurring vegetation in wetlands consisted of native species adapted to seasonal flooding and drainage (moist-soil conditions), including grasses (e.g., Echinochloa spp., Panicum spp.), forbs (Polygonum spp., Bidens spp., Xanthium strumarium), sedges and rushes (Cyperus spp., Juncus spp.), trees and shrubs (Salix nigra), and planted agricultural food plots.

\section{METHODS}

\section{Aquatic Invertebrate Sampling}

I collected invertebrate samples at a subsample of MBHI $(n=6)$ and WRP $(n=6)$ wetlands due to the large number of invertebrate samples collected and time required to process in the lab (approx. 3hr/sample). To assess invertebrate food availability for autumn migrating shorebirds, I collected invertebrate samples at study sites on a biweekly basis from August through mid-September. If shorebirds were present during a 
site visit, I collected invertebrate samples randomly within the location where I observed the majority of birds within the wetland. If no birds were detected at a site, I sampled and recorded habitat data randomly within the dominant vegetative cover in the wetland, excluding any areas with $>50 \%$ vegetative cover to prevent collecting invertebrate samples from microhabitats that were unlikely to be used by shorebirds (Davis and Smith 1998a). I also restricted sample locations to water depths at which shorebirds are expected to forage (mudflat to $16 \mathrm{~cm}$ water depth). During each site visit, I collected two 5-cm deep x 10-cm diameter soil core samples $\left(392.85 \mathrm{~cm}^{3}\right.$; Sherfy et al. 2000, Hamer et al. 2006, Davis and Bidwell 2008) to quantify benthic invertebrates. I washed soil samples through a $500 \mu \mathrm{m}$ mesh sieve bucket while in the field. I also collect two samples of nektonic invertebrates with a $500 \mu \mathrm{m}$ rectangular sweep net. I lowered the net into the water and dragged it along the bottom for a distance of $1.1 \mathrm{~m}\left(0.5 \mathrm{~m}^{2}\right.$ area $)$ (Wehrle et al. 1995, Gray et al. 1999). Soil core and water-column samples were stored in plastic storage bags with at least $70 \%$ ethanol and returned to the lab for processing (Murkin et al. 1994, Anderson et al. 2000).

To estimate invertebrate availability for waterfowl during winter I used a rectangular sweep net $(46 \mathrm{~cm} \times 20 \mathrm{~cm} ; 500 \mu \mathrm{m})$ to sample aquatic invertebrates bi-weekly from November through February ( $n=4$ sweeps/site/visit; Wehrle et al. 1995, Hagy and Kaminski 2012a). I stratified sites by dominant cover types: open water $(<50 \%$ vegetative cover) and vegetation ( $>50 \%$ vegetative cover) and collected 2 sweep samples at random locations within each cover type. If waterfowl were present, I collected samples and habitat data where the majority of birds were located within the wetland. If no birds were detected at a site, I collected samples randomly within dominant cover 
types at water depths $(15-60 \mathrm{~cm})$ which waterfowl are expected to forage (Dubowy 1988, Isola et al. 2000). According to published protocol, I vertically lowered the sweep net until it was pushed firmly against the substrate and bounced it along the bottom for $1.0 \mathrm{~m}$ to sample a $0.5 \mathrm{~m}^{2}$ area (Cheal et al. 1993, Gray et al. 1999, Hagy and Kaminski 2012a). I transported each sweep sample in a plastic bag for storage in at least $70 \%$ ethyl alcohol and later added rose bengal to facilitate sorting (Murkin et al. 1994, Anderson et al. 2000).

\section{Sample processing}

To facilitate sorting and identification, I stained invertebrate samples with rose bengal solution for 12-24 hours prior to processing (Sherfy et al 2000, Bolduc and Afton 2003). I filtered samples with running water through a series of sieves of decreasing mesh sizes $(500 \mu \mathrm{m}$ and $100 \mu \mathrm{m})$ to separate samples into coarse and fine samples, and facilitate sorting and identification (Bolduc and Afton 2003). Coarse samples were processed entirely, whereas fine samples were subsampled (1:2 to 1:32 of total) using a Folsom plankton splitter (Aquatic Research Instruments) prior to removal of macroinvertebrates (Whiting et al. 2011). The percent composition in the fine subsample was extrapolated and added to the coarse sample invertebrate abundance and biomass to estimate total fine sample invertebrate abundance and biomass in the overall sample. I

catalogued invertebrates by family and reported biomass $(\mathrm{kg} / \mathrm{ha})$ estimates for each taxon (Hagy and Kaminski 2012a). To obtain biomass estimates, I oven-dried specimens at $55^{\circ} \mathrm{C}$ for $\geq 24 \mathrm{~h}$ to a constant mass (to the nearest $0.01 \mathrm{mg}$ ) (Anderson and Smith 2000). Secondary production for each family was estimated using the size-frequency method and published annual or seasonal production/biomass (P/B) ratios for macroinvertebrates 
(Stagliano and Whiles 2002). According to published protocol, size-specific dry mass was estimated for all resident taxa using length-weight relationships obtained from Benke et al. (1999), Stagliano and Whiles (2002), and Evans-White et al. (2003). When P/B estimates for families were not available, I used estimates for individual species within that family that have been observed in habitats with similar environmental characteristics. I then calculated total bi-weekly and seasonal production for each study wetland.

\section{Data Analysis}

My assessment of invertebrate communities was coarse-grained (i.e., class, order, or family); I identified invertebrates to family when possible (Wehrle et al. 1995), however I was not able to identify invertebrates to species and thus determine species richness. I omitted the order Hemiptera from secondary production estimates due to inability to efficiently and accurately distinguish between adults and juveniles. I converted all invertebrate biomass, richness, and production estimates to densities (e.g., $\mathrm{kg} / \mathrm{ha}$, families/ha) to account for variation in wetland area. I analyzed data from each season (autumn and winter) separately because of differences in environmental conditions, sampling methodologies and invertebrate community composition. All tests were conducted using SAS/STAT ${ }^{\circledR} 9.2$, and $\alpha=0.05$ significance level (SAS Institute 2012).

I used Analysis of Variance (ANOVA) to test effects of the following independent variables on invertebrate biomass, familial richness, and ETP richness using the MIXED procedure (PROC MIXED; SAS Institute 2012): wetland type (WRP, MBHI, or Public), individual management activities (mowing/disking and active 
inundation), and site age. I tested for the interaction of each independent variable and site visit, and designated site as a random effect. For seasonal secondary production, which was a single value for each site, I used PROC GLM to test the effects of wetland type and management activities on production estimates.

During the autumn sampling season, I collected invertebrate samples with both a sweep net and core sampler. I used the MIXED procedure (PROC MIXED; SAS Institute 2012) to test the effects of sample method (core or sweep) on invertebrate biomass and familial richness and PROC GLM to test effects of sampling technique on secondary production. I designated sample method, site visit, and their interaction as fixed effects, and site as a random effect. Additionally, I tested differences between biweekly (every two weeks) and monthly invertebrate sampling by using a PROC T-TEST to comparing bi-weekly (independent variable) and monthly (dependent variable) invertebrate biomass means during winter.

\section{RESULTS}

Only one selected public site was inundated during August and early-September, therefore I omitted public as a wetland type from autumn analyses. Invertebrate biomass and production data were left skewed during each season, therefore I natural log transformed the data before analyses (Zar 1999). There were no interactions among fixed effects in the initial analyses of invertebrate metrics (all $p>0.15$ ). Additionally, WRP, MBHI and public wetlands were not always inundated or accessible concurrently during each season.

Autumn Results 
From 3 August through 16 September 2011, I collected 85 total invertebrate samples from 18 wetlands; however only 9 study wetlands contained water during this period. Mean invertebrate biomass was $23.88 \pm 1.48 \mathrm{~kg} / \mathrm{ha}(1.8-1895.9 \mathrm{~kg} / \mathrm{ha})$ in benthic core samples and $5.85 \pm 1.48 \mathrm{~kg} / \mathrm{ha}(0.01-125.47 \mathrm{~kg} / \mathrm{ha})$ in nektonic sweep samples. Mean core and sweep familial richness were $2.8( \pm 1.1)$ and $5.0( \pm 1.1)$ families/ha, respectively. Families Planorbidae (66\%), Corixidae (22\%), Physidae (4\%), Dytiscidae (2\%), Palaemonidae (2\%), Chironomidae (2\%), Hydrophilidae (1\%), and Haliplidae (1\%) accounted for $99 \%$ of total mass in sweep samples. Families Belostomatidae (45\%), Planorbidae (36\%), Physidae (4\%), Hirudidae (3\%), Lumbriculidae (3\%), Corixidae (2\%), Dytiscidae (1\%) accounted for $98 \%$ of total mass in core samples. Ephemeroptera, Plecoptera, and Trichoptera families comprised less than $1 \%$ of total invertebrate biomass. Biomass, familial richness, and production differed between sampling techniques in autumn. Benthic core biomass estimates were approximately 4 times greater than nektonic sweep estimates $\left(\mathrm{F}_{1,16}=6.32 ; \mathrm{p} \leq 0.05\right.$, Table 2.1). Conversely, sweep familial richness estimates were $50 \%$ greater than benthic core estimates $\left(\mathrm{F}_{1,16}=18.75 ; \mathrm{p} \leq 0.05\right.$; Table 2.1$)$. Sweep production estimates were also $60 \%$ greater than benthic core production estimates, regardless of wetland type $\left(\mathrm{F}_{1,16}=5.54 ; \mathrm{p}\right.$ $\leq 0.05$; Table 2.1, Figure 2.1).

Invertebrate biomass $\left(\mathrm{F}_{1,6}=1.15, p=0.32\right)$, familial richness $\left(\mathrm{F}_{1,6}=0.33, p=\right.$ 0.59), and ETP richness $\left(\mathrm{F}_{1,6}=0.97, p=0.36\right)$ did not differ between wetland types (Table 2.2). However, invertebrate production at MBHI wetlands was two times greater than at WRP wetlands $\left(\mathrm{F}_{1,19}=19.74 ; p \leq 0.05\right.$; Figure 2.2). Mowing did not affect invertebrate biomass $\left(\mathrm{F}_{1,6}=0.20, p=0.67\right)$ or richness $\left(\mathrm{F}_{1,6}=0.61, p=0.47\right)$ at private 
lands regardless of wetland type (Table 2.3). Similarly, active inundation had no effect on invertebrate biomass $\left(\mathrm{F}_{1,6}=1.40, p=0.28\right)$ or richness $\left(\mathrm{F}_{1,6}=0.62, p=0.46\right.$; Table 2.3). Invertebrate production at wetlands that were mowed was approximately 4 times greater compared to wetlands that were not mowed $\left(\mathrm{F}_{1,19}=9.21, p \leq 0.05\right)$. Active inundation had no effect on invertebrate production $\left(\mathrm{F}_{1,19}=0.00 ; p=0.96\right)$. Additionally, invertebrate biomass $\left(\mathrm{F}_{1,6}=0.57, p=0.48\right)$, richness $\left(\mathrm{F}_{1,6}=2.70, p=0.15\right)$, and production $\left(\mathrm{F}_{1,20}=1.17, p=0.29\right)$ did not differ between younger and older WRP wetlands (i.e. site age).

\section{Winter Results}

From 3 November 2011 through 24 February 2012, I collected 516 total invertebrate samples from 19 wetlands. Invertebrate biomass ranged from $0.0-60.3$ $\mathrm{kg} / \mathrm{ha}$ in sweep samples. Invertebrate familial richness varied from $0.0-14.0$. I observed 85 families in winter sweep samples, compared to 43 families in autumn sweep samples. Families Planorbidae (21\%), Cambaridae (17\%), Physidae (9\%), Asellidae (6\%), Chironomidae (6\%), Daphniidae (6\%), Naididae (5\%), Dytiscidae (5\%), Palaemonidae (5\%), Corixidae (4\%), Hyrdophilidae (3\%), Copepoda (2\%), Gammaridae (2\%), and Belostomatidae (1\%) comprised $90 \%$ of the total biomass in winter sweep samples. Ephemeroptera, Plecoptera, and Trichoptera families comprised less than $1 \%$ of total invertebrate biomass. Invertebrate biomass $\left(\mathrm{F}_{2,16}=0.17, p=0.85\right)$, familial richness $\left(\mathrm{F}_{2,16}=0.16, p=0.70\right)$, or ETP richness $\left(\mathrm{F}_{2,16}=0.05, p=0.83\right)$ did not differ among wetland types (Table 2.2). Invertebrate production differed among wetland types $\left(\mathrm{F}_{2,146}=\right.$ $3.09 ; \mathrm{p} \leq 0.05)$. Invertebrate production at WRP wetlands $\left(2.58[ \pm 1.06] \mathrm{kg} / \mathrm{ha}{ }^{*}\right.$ season $)$ and MBHI wetlands $(2.31[ \pm 1.06] \mathrm{kg} / \mathrm{ha}$ *season) were greater than production at public 
wetlands $(1.65[ \pm 1.06] \mathrm{kg} / \mathrm{ha}$ *season; both $p<0.05$; Figure 2.2-2.3). However, invertebrate production did not differ between WRP and MBHI wetlands $(p=0.21)$.

Mowing did not affect invertebrate biomass $\left(\mathrm{F}_{1,17}=0.56, p=0.46\right)$, richness $\left(\mathrm{F}_{1,17}\right.$ $=0.00, p=0.96)$, or production $\left(\mathrm{F}_{1,147}=1.97, p=0.16\right)$ at private lands regardless of wetland type (Table 2.3). Similarly active inundation had no effect on invertebrate biomass $\left(\mathrm{F}_{1,17}=0.92, p=0.35\right)$, richness $\left(\mathrm{F}_{1,17}=1.56, p=0.46\right)$ or production $\left(\mathrm{F}_{1,147}=\right.$ $0.69, p=0.41$; Table 2.3). Additionally, invertebrate biomass $\left(\mathrm{F}_{1,17}=2.60, p=0.13\right)$, richness $\left(\mathrm{F}_{1,17}=3.99, p=0.06\right)$, and production $\left(\mathrm{F}_{1,147}=0.15, p=0.70\right)$ did not differ between younger and older WRP wetlands. I also tested for an effect of sampling frequency on invertebrate biomass during winter and found no difference between monthly and bi-weekly sampling (t-test $=-0.45, p=0.65)$.

\section{DISCUSSION}

I evaluated aquatic invertebrate responses to management at WRP wetlands that have been enrolled in the MBHI and at reference wetlands (WRP [not-enrolled in the $\mathrm{MBHI}$ and public) during autumn and winter 2011. Secondary production of invertebrates proved to be the only metric for which differences occurred among wetland type and management practices, and thus may provide insight regarding aquatic invertebrate response to moist-soil management. Mowing of vegetation has been proven to increase detritus in seasonal wetlands (Gray et al. 1999, Anderson and Smith 2000, Kostecke et al. 2005). Vegetative manipulation and increased detritus may have been the cause for increased invertebrate production in MBHI wetlands (Table 2.1), considering that none of the reference WRP wetlands that were inundated during autumn were mowed. Additionally, substantial dry periods can increase decomposition and 
productivity of aquatic plants, which increases availability of detritus for invertebrates (Kadlec 1962, Mitsch and Gosselink 2007, Anderson and Smith 2000, Davis and Bidwell 2008). Moderate drought conditions in Arkansas and Missouri during summer and autumn 2011 (NOAA 2012) affected landowner ability to provide habitat for autumn migrating shorebirds, causing approximately $50 \%$ of my study sites to remain dry through November. While most of the public reference wetlands were not inundated during autumn, the soils did not appear to dry out completely (J. Tapp, personal observation) and may explain why these wetlands exhibited reduced invertebrate production in winter.

Production estimates from sweep samples were composed primarily of Planorbidae (ramshorn snails), Corixidae (water boatmen), Cambaridae (crayfish), Physidae (bladder snails), Dytiscidae (diving beetles), Asellidae (pillbugs), Chironomidae (midges), and Daphniidae (water fleas), many of which are commonly found in shorebird and dabbling duck diets. Similarly, Duffy and LaBar (1994) found that the greatest taxa contributors to invertebrate production were larger taxa also found in waterbird diets. Other studies that investigated community composition found that many of the same taxa observed in this study to be the most abundant in seasonal wetlands (De Szalay and Resh 1997, Anderson and Smith 2000, Hagy and Kaminski 2012). In addition, production estimates at private wetlands were similar to another study at Noxubee National Wildlife Refuge in Mississippi (Duffy and LaBar 1994).

I was unable to detect any effects of moist-soil management on invertebrate biomass or richness at private or public wetlands. However, several studies have shown that moist-soil management can positively influence invertebrate biomass and taxon 
richness (Gray et al. 1999, Anderson and Smith 2000, Kostecke et al. 2005, Davis and Bidwell 2008). Conversely, some of the same studies reported the greatest invertebrate diversities and/or biomass at wetlands that received no additional management (Gray et al. 1999, De Szalay and Resh 2000, Kostecke et al. 2005, Hagy and Kaminski 2012). Aquatic invertebrate populations may be most successful in wetlands with complex habitat structures (Krull 1970, Voights 1976, Nelson and Kadlec 1984, Olson et al. 1995). Both Voigts (1976) and Davis and Bidwell (2008) reported that abundance of aquatic invertebrates was greatest when submerged and emergent vegetation were highly interspersed.

I also evaluated the effect of sampling methods on aquatic invertebrate estimates. I found the majority of biomass in core samples, while sweep samples displayed greater familial richness. Wetland invertebrate studies should consider objectives carefully when determining sampling methods. Failure to sample both nektonic and benthic invertebrates in seasonal wetlands may cause studies to underestimate common aquatic invertebrate metrics (Fredrickson and Reid 1988, Hagy and Kaminski 2012). I found no difference between samples taken once per month and samples taken twice per month, therefore I suggest reducing invertebrate sampling frequency to reduce sample processing time only if secondary production is not a variable of interest. Collecting a greater number of samples per wetland less frequently may help reduce the variability of invertebrate metrics by accounting for patchy distributions of invertebrates within wetlands (Downing 1991).

Inability to detect patterns in invertebrate response (biomass and richness) to moist-soil management may be because invertebrates are simultaneously influenced by 
numerous ecological and environmental factors such as detritus, hydrology, water chemistry, and predation (Batzer 2013). While I did not quantify detritus, mowing and disking to manipulate vegetation may have different effects on the structure and density of emergent vegetation and submerged detritus (Voigts 1976, Neckles 1990, Gray et al. 1999, De Szalay and Resh 2000). Detritus is an important component of aquatic invertebrate diets and may be positively associated with invertebrate biomass and diversity (Murkin et al. 1982, Gray et al. 1999, De Szalay and Resh 2000, Davis and Bidwell 2008). Although I did not sample for fish, I observed many fish specimens in my sweep samples. Predators such as fish can also affect aquatic invertebrate populations (Pehrsson 1984, Batzer and Resh 1992). Leao (2005) found that WRP easements can provide important habitat for fish, provided the wetlands are connected to a river system during overbank flows. Approximately 25\% of WRP easements in Arkansas are flooded by overbank or backwater flooding (King et al. 2006). The presence of fish has been suspected to limit invertebrate resources for migratory waterbirds (Pehrsson 1984, King et al. 2006) and may explain some of the variation in invertebrate biomass and richness I observed among private wetlands. Variation in taxonomic diversity among wetlands has also been explained by characteristics of the surrounding watershed (Hall et al. 2004). A study of adult chironomid distribution in agricultural landscapes found that both taxonomic richness and number of individuals at study sites were determined by distance to streams (Delettre and Morvan 2008). Adult taxa with wings may fly to other wetlands if environmental conditions at a site become unsuitable. Flight distances can range from a few yards up to 50 miles (Fredrickson and Reid 1988). Therefore, ability to detect differences in invertebrate metrics among wetland types and management strategies may 
have been compromised by variation caused by other environmental and ecological factors known to influence wetland invertebrate communities.

There was no difference of ETP indices among management activities or wetland types. The families that contribute to ETP indices made up less than $1 \%$ of total invertebrate biomass (see Appendix A). Low presence of ETP taxa has been related to poor water quality, however the ETP index is a rapid assessment protocol normally used in streams with greater oxygen content (Grandjean et al. 2003). That invertebrate production, biomass and community composition at WRP wetlands were similar to other studies suggests that ETP richness may not be an accurate indicator of moist-soil wetland integrity. Still, Batzer (2013) suggested that the study of specific groups of invertebrates may lead to clearer implications. Invertebrates with the ability to disperse may not be as definitively linked to habitat conditions as resident invertebrates because of their ability to relocate when conditions become unfavorable (Batzer 2013). Invertebrate biomass and richness results among study wetlands were likely biased due to variable wetland use by strong dispersers (Batzer 2013). By default, the evaluation of secondary production targets individuals that do not have the ability to disperse, which may have helped reduce variability among wetlands in my study. Future studies of invertebrate response to wetland management should consider quantifying secondary production and identifying to genus or species to help isolate which types of invertebrates are most influenced by moist-soil management (Batzer 2013).

\section{MANAGEMENT IMPLICATIONS}

Aquatic invertebrates are likely well adapted to and benefit from dry summers that often occur in the LMAV, therefore managers should let seasonal wetlands dry 
completely during the summer when possible (Reinecke et al., 1989, Batzer 2013). While WRP wetlands tend to have variable hydroperiods, they can exhibit greater invertebrate and seed production than stable/predictable systems such as long term managed wetlands with the help of MBHI management (Benke 2013, Olmstead et al. 2013). The variability of invertebrate responses to habitat manipulations during my study indicates that mowing strips of moist-soil vegetation within a wetland, while leaving portions unmanipulated, may support the greatest invertebrate mass and diversity in autumn and winter (Gray et al. 1999, Hagy and Kaminski 2012). My results demonstrate that WRP wetlands in Arkansas and Missouri can be an important source of aquatic invertebrate production via MBHI management. Considering the complex and variable nature of seasonal wetlands, I suggest an adaptive management approach for not only MBHI funded wetlands, but all moist-soil wetlands (Lyons et al. 2008, Benke 2013). Frequent monitoring of vegetative and invertebrate responses of wetlands to management will help to guide future management decisions (Fleming 2012). 


\section{LITERATURE CITED}

Anderson, J. T. and L. M. Smith. 1998. Protein and energy production in playas: Implications for migratory bird management. Society of Wetland Scientists 18:437-446.

Anderson, J. T. and L. M. Smith. 2000. Invertebrate response to moist-soil management of playa wetlands. Ecological Applications 10:550-558.

Anderson, J. T. and L. M. Smith. 2002. The effect of flooding regimes on decomposition of $<$ i $>$ Polygonum pensylvanicum $</ i>$ in playa wetlands (Southern Great Plains, USA). Aquatic botany 74:97-108.

Batzer, D. P. 2013. The seemingly intractable ecological responses of invertebrates in North American wetlands: a review. Wetlands 33:1-15.

Batzer, D. P. and V. H. Resh. 1992. Macroinvertebrates of a California seasonal wetland and responses to experimental habitat manipulation. Wetlands 12:1-7.

Benke, A. C. 1984. Secondary production of aquatic insects. Pages 289-322 in V. H. Resh and D. M. Rosenberg, editors. The ecology of aquatic insects, Praeger, New York, New York, USA.

Benke, A. C. 1993. Concepts and patterns of invertebrate production in running waters. Verh. Internat. Verein. Limnol. 25:15-38.

Benke, A. C. 2010. Secondary production as part of bioenergetic theory-contributions from freshwater benthic science. River Research and Applications 26:36-44.

Benke, A. C. and A. D. Huryn. 2010. Benthic invertebrate production-facilitating answer to ecological riddles in freshwater ecosystems. Journal of North American Benthological Society 29:264-285.

Bolduc, F. and A. D. Afton. 2003. Effects of structural marsh management and salinity on invertebrate prety of waterbirds in marsh ponds during winter on the Gulf Coast Chenier Plain. Wetlands 23:897-910.

Bolduc, F. and A. D. Afton. 2004. Relationships between wintering waterbirds and invertebrates, sediments and hydrology of coastal marsh ponds. Waterbirds 27:333-341.

Bried, J. T. and G. N. Ervin. 2005. Distribution of adult Odonata among localized wetlands in East-Central Mississippi. Southeastern Naturalist 4:731-744.

Callicutt, J. T., H. M. Hagy, and M. L. Schummer. 2011. The Food Preference Paradigm: A Review of Autumn-Winter Food Use by North American Dabbling Ducks (1900-2009). Journal of Fish and Wildlife Management 2:29-40. 
Cheal, F., J. Davis, J. Growns, J. Bradley, and F. Whittles. 1993. The influence of sampling method on the classification of wetland macroinvertebrate communities. Hydrobiologia 257:47-56.

Collazo, J. A., D. A. O'Harra, and C. A. Kelly. 2002. Accessible habitat for shorebirds: Factors influencing its availability and conservation implications. Waterbirds 25:13-24.

Colwell, M. A. and O. W. Taft. 2000. Waterbird communities in managed wetlands of varying water depth. Waterbirds 23:45-55.

Danell, K. and K. Sjoberg. 1982. Successional patterns of plants, invertebrates and ducks in a man-made lake. Journal of Applied Ecology:395-409.

Davis, C. A. and J. R. Bidwell. 2008. Response of aquatic invertebrates to vegetation management and agriculture. . Wetlands 28:793-805.

Delettre, Y. R. and N. Morvan. 2000. Dispersal of adult aquatic Chironomidae (Diptera) in agricultural landscapes. Freshwater Biology 44:399-411.

De Szalay, F. A., D. P. Batzer, and V. H. Resh. 1996. Mesocosm and macrocosm experiments to examine effects of mowing emergent vegetation on wetland invertebrates. . Environmental Entomology 25:303-309.

De Szalay, F. A. and V. H. Resh. 1997. Responses of wetland invertebrates and plants important in waterfowl diets to burning and mowing of emergent vegetation. Wetlands 17:149-156.

De Szalay, F. A. and V. H. Resh. 2000. Factors influencing macroinvertebrate colonization of seasonal wetlands: responses to emergent plant cover. Freshwater Biology 45:295-308.

Drent, R. H. 2006. The timing of birds' breeding seasons: the Perrins hypothesis revisited especially for migrants. Ardea 94:305-322.

Doğramaci, M., S. J. DeBano, D. E. Wooster, and C. Kimoto. 2010. A method for subsampling terrestrial invertebrate samples in the laboratory: Estimating abundance and taxa richness. Journal of Insect Science 10:1-17.

Downing, J. A. 1991. The effect of habitat structure on the spatial distribution of freshwater invertebrate populations. Pages 87-106 in S. S. Bell, E. D. McCoy, and H. R. Mushinsky, editors. Habitat structure. Springer Netherlands.

Duffy, W. G. and D. J. LaBar. 1994. Aquatic invertebrate production in southeastern USA wetlands during winter and spring. Wetlands 14:88-97.

Euliss, N. and G. Grodhaus. 1987. Management of midges and other invertebrates for waterfowl wintering in California. California Fish and Game 73:238-243. 
Euliss, N. H. and D. M. Mushet. 1999. Influence of agriculture on aquatic invertebrate communities of temporary wetlands in the Prairie Pothole Region of North Dakota, USA. Wetlands 19:578-583.

Fredrickson, L. H. 1991. 13.4. 6. Strategies for Water Level Manipulations in Moist-soil Systems. Waterfowl management handbook: Paper 26.

Fredrickson, L. H. and F. A. Reid. 1988. Invertebrate response to wetland management. in F. a. W. S. U.S. Department of the Interior, editor. Waterfowl Management Handbook., Fort Collins, Colorado.

Fredrickson, L. H. and T. S. Taylor. 1982. Management of seasonally flooded impoundments for wildlife. U. S. Fish and Wildlife Service, Resource Publication 148.

Gawlik, D. E. 2002. The effects of prey availability on the numerical response of wading birds. Ecologiocal Monographs 72:329-346.

Grandjean, F., J. Momon, and M. Bramard. 2003. Biological water quality assessment of the Whiteclawed Crayfish habitat based on macroinvertebrate communities: usefulness for its conservation. Bulletin Français de la Pêche et de la Pisciculture:115-125.

Gray, R. L. and B. M. Teels. 2006. Wildlife and fish conservation through the Farm Bill. Wildlife Society Bulletin 34:906-913.

Gray, M. J., R. M. Kaminski, G. Weerakkody, B. D. Leopold, and K. C. Jensen. 1999. Aquatic invertebrate and plant responses following mechanical manipulations of moist-soil habitat. Wildlife Society Bulletin 27:770-779.

Griffith, M., S. Perry, and W. Perry. 1994. Secondary production of macroinvertebrate shredders in headwater streams with different baseflow alkalinity. Journal of the North American Benthological Society: 345-356.

Hagy, H. M. and R. M. Kaminski. 2012. Winter waterbird and food dynamics in autumnmanaged moist-soil wetlands in the Mississippi Alluvial Valley. Wildlife Society Bulletin 36:512-523.

Hall, D. L., M. R. Willig, D. L. Moorhead, R. W. Sites, E. B. Fish, and T. R. Mollhagen. 2004. Aquatic macroinvertebrate diversity of playa wetlands: the role of landscape and island biogeographic characteristics. Wetlands 24:77-91.

Hamer, G. L., E. J. Heske, J. D. Brawn, and P. W. Brown. 2006. Migrant shorebird predation on benthic invertebrates along the Illinois river, Illinois. The Wilson Journal of Ornithology 188:152-163. 
Harrington, B. A. 2003. Shorebird management during the non-breeding season - an overview of needs, opportunities, and management concepts. Water Study Group Bulletin 100.

Haukos, D. A. and L. M. Smith. 1993. Moist-soil management of playa lakes for migrating and wintering ducks. Wildlife Society Bulletin: 288-298.

Haukos, D. A. and L. M. Smith. 1995. Chemical composition of seeds from plants in playa wetlands. Wildlife Society Bulletin: 514-519.

Helgen, J. C. and M. C. Gernes. 2001. Monitoring the condition of wetlands: indexes of biological integrity using invertebrates and vegetation. IN: RB Rader, DP Batzer, and SA Wissinger (eds.), Bioassessment and Management of North American Freshwater Wetlands, John Wiley and Sons, New York, NY:167-185.

Helmers, D. L. 1992. Shorebird management manual. Western Hemisphere Shorebird Reserve Network, Manomet, Massachusetts.

Heitmeyer, M. E. and L. H. Fredrickson. 1981. Do wetland conditions in the Mississippi Delta hardwoods influence Mallard recruitment. Pages 44-57 in North American Wildlife and Natural Resources Conference.

Huryn, A. C. and J. B. Wallace. 2000. Life history and production of stream insects. Annual Review of Entomology 45: 83-110.

Kaminski, R. M., J. B. Davis, H. W. Essig, P. D. Gerard, and K. J. Reinecke. 2003. True metabolizable energy for wood ducks from acorns compared to other waterfowl foods. The Journal of Wildlife Management 67(3):542-550.

King, S. L., D. J. Twedt, and R. R. Wilson. 2006. The role of the Wetland Reserve Program in conservation efforts in the Mississippi Alluvial Valley. The Wildlife Society Bulletin 34:914-920.

Kostecke, R. M., L. M. Smith, and H. M. Hands. 2005. Macroinvertebrate response to cattail management at Cheyenne Bottoms, Kansas, USA. . Wetlands 25:758-763.

Krapu, G. L. and K. J. Reinecke. 1992. Foraging ecology and nutrition. Ecology and management of breeding waterfowl: 1-29.

Kostecke, R. M., L. M. Smith, and H. M. Hands. 2005. Macroinvertebrate response to cattail management at Cheyenne Bottoms, Kansas, USA. . Wetlands 25:758-763.

Kross, J., R. M. Kaminski, K. J. Reinecke, E. J. Penny, and A. T. Pearse. 2008. MoistSoil Seed Abundance in Managed Wetlands in the Mississippi Alluvial Valley. The Journal of Wildlife Management 72:707-714. 
Leao, M. 2005. Fish utilization and diversity associated with created wetlands within the Lower White River Watershed, Arkansas. Thesis, University of Arkansas at Pine Bluff, USA.

Lindegaard, C. 1994. The role of zoobenthos in energy flow in two shallow lakes. Hydrobiologia 275:313-322.

Lyons, J. E., M. C. Runge, H. P. Laskowski, and W. L. Kendall. 2008. Monitoring in the Context of Structured Decision-Making and Adaptive Management. The Journal of Wildlife Management 72:1683-1692.

Mahmut, D., S. J. DeBano, D. E. Wooster, and C. Kimoto. 2010. A method for subsampling terrestrial invertebrate samples in the laboratory: estimating abundance and taxa richness. Journal of Insect Science 10:1-17.

Malmqvist, B. 2002. Aquatic invertebrates in riverine landscapes. Freshwater Biology 47:679-694.

Manley, S. W., M. R. Kaminski, K. J. Reinecke, and P. D. Gerard. 2004. Waterbird foods in winter-managed ricefields in Mississippi. Journal of Wildlife Management 68:74-83.

Meyer, C. K., S. D. Peterson, and M. R. Whiles. 2011. Quantitative assessment of yield, precision, and cost-effectiveness of three wetland invertebrate sampling techniques. Wetlands 31:101-112.

Miller, A. T., M. A. Hanson, J. O. Church, B. Palik, S. E. Bowe, and M. G. Butler. 2008. Invertebrate community variation in seasonal forest wetlands: implications for sampling and analyses. Wetlands 28:874-881.

Mitchell, D. W. and J. W. Grubaugh. 2005. Impacts of shorebirds on macroinvertebrates in the Lower Mississippi Alluvial Valley. American Midland Naturalist 154:188200.

Mitsch, W. J. and J. G. Gosselink. 2007. Wetlands. Fourth Edition. John Wiley and Sons, Inc, Hoboken, New Jersey, USA.

Murkin, H. R. and D. A. Wrubleski. 1988. Aquatic invertebrates of freshwater wetlands: function and ecology In Ecology and management of wetlands. Croom Helm, London, England.

Murkin, H. R., D. A. Wrubleski, and F. Reid. 1994. Sampling invertebrates in aquatic and terrestrial habitats. Pages 349-369 in T. A. Bookhout, editor. Research and Management Techniques for Wildlife and Habitats. The Wildlife Society, Bethesda, MD, USA. 
Murphy, P. M. and M. A. Learner. 1982. The life history and production of Asellus aquaticus (Crustacea: Isopoda) in the River Ely, South Wales. Freshwater Biology $12: 435-444$.

Newton, I. 2006. Can conditions experienced during migration limit the population levels of birds? Journal of Ornithology 147:146-166.

Oertli, B. 1993. Leaf litter processing and energy flow through macroinvertebrates in a woodland pond (Switzerland). Oecologia 96:466-477.

Pehrsson, O. 1984. Relationships of food to spatial and temporal breeding strategies of mallards in Sweden. The Journal of Wildlife Management 48:322-339.

Reid, F. A., J. R. Kelly, Jr., T. S. Taylor and L. H. Fredrickson. 1989. Upper Mississippi Valley wetlands- refuges and moist-soil impoundments, p. 181-202. In: L. M. Smith, R. L. Pederson and R. M. Kaminski (eds.). Habitat management for migrating and wintering waterfowl in North America. Texas Tech University Press, Lubbock, Texas.

Reinecke, K. J., R. M. Kaminski, D. J. Moorhead, J. D. Hodges, and J. R. Nassar. 1989. Mississippi Alluvial Valley. Pages 203-247 in L. M. Smith, R. L. Pederson, and R. M. Kaminski, editors. Habitat management for migrating and wintering waterfowl in North America. Texas Tech University Press, Lubbock, USA.

Safran, R. J., C. R. Isola, M. A. Colwell, and O. E. Williams. 1997. Benthic invertebrates at foraging locations of nine waterbird species in managed wetlands of the northern San Joaquin Valley, California. Wetlands 17:407-415.

Sherfy, M. H., R. L. Kirkpatrick, and K. D. Richkus. 2000. Benthos core sampling and chironomid vertical distribution: implications for assessing shorebird food availability. Wildlife Society Bulletin 28:124-130.

Smock, L. A., E. Gilinsky, and D. L. Stoneburner. 1985. Macroinvertebrate production in a southeastern United States blackwater stream. Ecology:1491-1503.

Stanczak, M. and J. B. Keiper. 2004. Benthic invertebrates in adjacent created and natural wetlands in Northeastern Ohio, USA. Wetlands 24:212-218.

Swanson, G. A. and M. I. Meyer. 1977. Impact of fluctuating water levels on feeding ecology of breeding blue-winged teal. The Journal of Wildlife Management 41(3): 426-433.

Tidwell, P. R., E. B. Webb, M. P. Vrtiska, and A. A. Bishop. 2013. Diets and Food Selection of Female Mallards and Blue-Winged Teal During Spring Migration. Journal of Fish and Wildlife Management 4:63-74.

Vannote, R. L., G. W. Minshall, K. W. Cummins, J. R. Sedell, and C. E. Cushing. 1980. The river continuum concept. Can. J. Fish. Aquat. Sci. 37:130-137. 
Voigts, D. K. 1976. Aquatic invertebrate abundance in relation to changing marsh vegetation. American Midland Naturalist 95:313-322.

Wehrle, B. W., R. M. Kaminski, B. D. Leopold, and W. P. Smith. 1995. Aquatic invertebrate resources in Mississippi forested wetlands during winter. Wildlife Society Bulletin 23:774-783.

Whiting, D. P., M. R. Whiles, and M. L. Stone. 2011. Patterns of macroinvertebrate production, trophic structure, and energy flow along a tallgrass prairie stream continuum. Limnologcial Oceanographer 56:887-898.

Wiggins, G. B., R. J. Mackay, and I. M. Smith. 1980. Evolutionary and ecological strategies of animals in annual temporary pools. Archiv für Hydrobiologie supplement 58:97-206.

Williams, D. D. 1987. A laboratory study of predator-prey interactions of stoneflies and mayflies. Freshwater Biology 17:471-490.

Zar, J. H. 1999. Biostatistical analysis. Prentice Hall, Upper Saddle River, New Jersey, USA.

Zimmer, K. D., M. A. Hanson, and M. G. Butler. 2000. Factors influencing invertebrate communities in prairie wetlands: a multivariate approach. Canadian Journal of Aquatic Sciences 57:76-85. 
Table 2.1. Mean $(\overline{\boldsymbol{x}} \pm \mathrm{SE})$ aquatic invertebrate biomass $(\mathrm{kg} / \mathrm{ha})$, familial richness (families/ha), and secondary production (kg/ha*season) by aquatic sweep and benthic core sampling techniques at seasonal wetlands $(n=12)$ enrolled in the Wetland Reserve Program in Arkansas and Missouri during Aug-Sept 2011.

\begin{tabular}{lccc}
\hline & Sweep & Core & Total \\
\cline { 2 - 4 } Biomass & $5.85 \pm 1.48 \mathrm{~A}^{\mathrm{a}}$ & $23.88 \pm 1.48 \mathrm{~B}$ & $11.96 \pm 1.29$ \\
Familial Richness & $4.62 \pm 0.50 \mathrm{~A}$ & $1.93 \pm 0.19 \mathrm{~B}$ & $3.74 \pm 1.07$ \\
Production & $1.51 \pm 1.02 \mathrm{~A}$ & $0.41 \pm 0.19 \mathrm{~B}$ & $1.57 \pm 1.09$ \\
\hline aMeans within rows followed by unlike capital letters differ $(P \leq 0.05)$ by ANOVAs.
\end{tabular}

${ }^{a}$ Means within rows followed by unlike capital letters differ $(P \leq 0.05)$ by ANOVAs. 
Table 2.2. Mean $(\overline{\boldsymbol{x}} \pm \mathrm{SE})$ aquatic invertebrate biomass $(\mathrm{kg} / \mathrm{ha})$, familial richness (families/ha), secondary production (kg/ha*season), and Ephemeroptera, Trichoptera, and Plecoptera (ETP) richness (families/ha) and comparisons among Migratory Bird Habitat Initiative (MBHI) wetlands ( $n=6)$, Wetland Reserve Program (WRP) wetlands $(n=6)$, and publicly owned wetlands $(n=7)$ wetlands in Arkansas and Missouri during autumn 2011 and winter 2011-2012.

\begin{tabular}{|c|c|c|c|c|}
\hline \multirow[b]{2}{*}{ Autumn $2011^{1}$} & & MBHI & WRP & Public \\
\hline & Biomass & $29.33 \pm 1.52 \mathrm{~A}$ & $57.31 \pm 1.59 \mathrm{~A}$ & -- \\
\hline \multirow{7}{*}{ Winter $11-12^{2}$} & Familial Richness & $6.17 \pm 0.87 \mathrm{~A}$ & $7.06 \pm 0.65 \mathrm{~A}$ & -- \\
\hline & Production & $1.98 \pm 0.002 \mathrm{~A}$ & $0.10 \pm 0.002 \mathrm{~B}$ & -- \\
\hline & ETP Richness & $0.13 \pm 0.33 \mathrm{~A}$ & $0.33 \pm 0.14 \mathrm{~A}$ & -- \\
\hline & Biomass & $3.53 \pm 1.20 \mathrm{~A}$ & $3.12 \pm 1.20 \mathrm{~A}$ & $3.10 \pm 1.19 \mathrm{~A}$ \\
\hline & Familial Richness & $4.95 \pm 0.40 \mathrm{~A}$ & $5.23 \pm 0.37 \mathrm{~A}$ & $5.85 \pm 0.42 \mathrm{~A}$ \\
\hline & Production & $2.31 \pm 1.06 \mathrm{~A}$ & $2.58 \pm 1.06 \mathrm{~A}$ & $1.65 \pm 1.06 \mathrm{~B}$ \\
\hline & ETP Richness & $4.23 \pm 0.34 \mathrm{~A}$ & $4.43 \pm 0.33 \mathrm{~A}$ & $4.74 \pm 0.36 \mathrm{~A}$ \\
\hline
\end{tabular}


Table 2.3. Mean $\left(\overline{\boldsymbol{x}}_{ \pm} \mathrm{SE}\right)$ aquatic invertebrate biomass $(\mathrm{kg} / \mathrm{ha})$, familial richness (families/ha), and secondary production ( $\mathrm{kg} / \mathrm{ha}{ }^{*}$ season) by individual management activities at private wetlands (Wetland Reserve Program and Migratory Bird Habitat Initiative; $n=12$ ) in Arkansas and Missouri during autumn 2011 and winter 20112012.

\begin{tabular}{|c|c|c|c|c|c|c|c|}
\hline & & \multicolumn{2}{|c|}{ Mowing/Disking } & \multicolumn{2}{|c|}{ Active Inundation } & \multicolumn{2}{|c|}{ Site Age } \\
\hline & & Yes & No & Yes & No & $0-10 y r s$ & $10-20 y r s$ \\
\hline \multirow{3}{*}{$\begin{array}{l}\text { Autumn } \\
2011^{1}\end{array}$} & Biomass & $47.87 \pm 1.53$ & $35.51 \pm 1.67$ & $60.97 \pm 1.58$ & $29.48 \pm 1.51$ & $51.03 \pm 1.51$ & $31.20 \pm 1.66$ \\
\hline & $\begin{array}{l}\text { Familial } \\
\text { Richness }\end{array}$ & $7.13 \pm 0.67$ & $5.78 \pm 0.96$ & $7.28 \pm 0.89$ & $6.0 \pm 0.72$ & $7.5 \pm 0.80$ & $5.28 \pm 0.58$ \\
\hline & Production & $0.54 \pm 0.31$ & $4.14 \pm 1.97$ & $0.71 \pm 0.36$ & $3.11 \pm 1.72$ & $0.91 \pm 0.32$ & $3.64 \pm 2.18$ \\
\hline \multirow{3}{*}{$\begin{array}{l}\text { Winter } \\
11-12^{2}\end{array}$} & Biomass & $3.53 \pm 1.18$ & $3.01 \pm 1.14$ & $3.60 \pm 1.14$ & $2.98 \pm 1.15$ & $2.88 \pm 1.13$ & $3.85 \pm 1.14$ \\
\hline & $\begin{array}{l}\text { Familial } \\
\text { Richness }\end{array}$ & $5.30 \pm 0.37$ & $4.91 \pm 0.37$ & $5.25 \pm 0.37$ & $4.86 \pm 0.44$ & $4.73 \pm 0.33$ & $5.60 \pm 0.49$ \\
\hline & Production & $1.58 \pm 0.43$ & $1.90 \pm 0.70$ & $1.70 \pm 0.57$ & $1.72 \pm 0.65$ & $1.76 \pm 0.45$ & $1.82 \pm 0.81$ \\
\hline
\end{tabular}

${ }^{1}$ Means calculated from combining core and sweep samples.

${ }^{2}$ Means calculated from sweep samples only. 


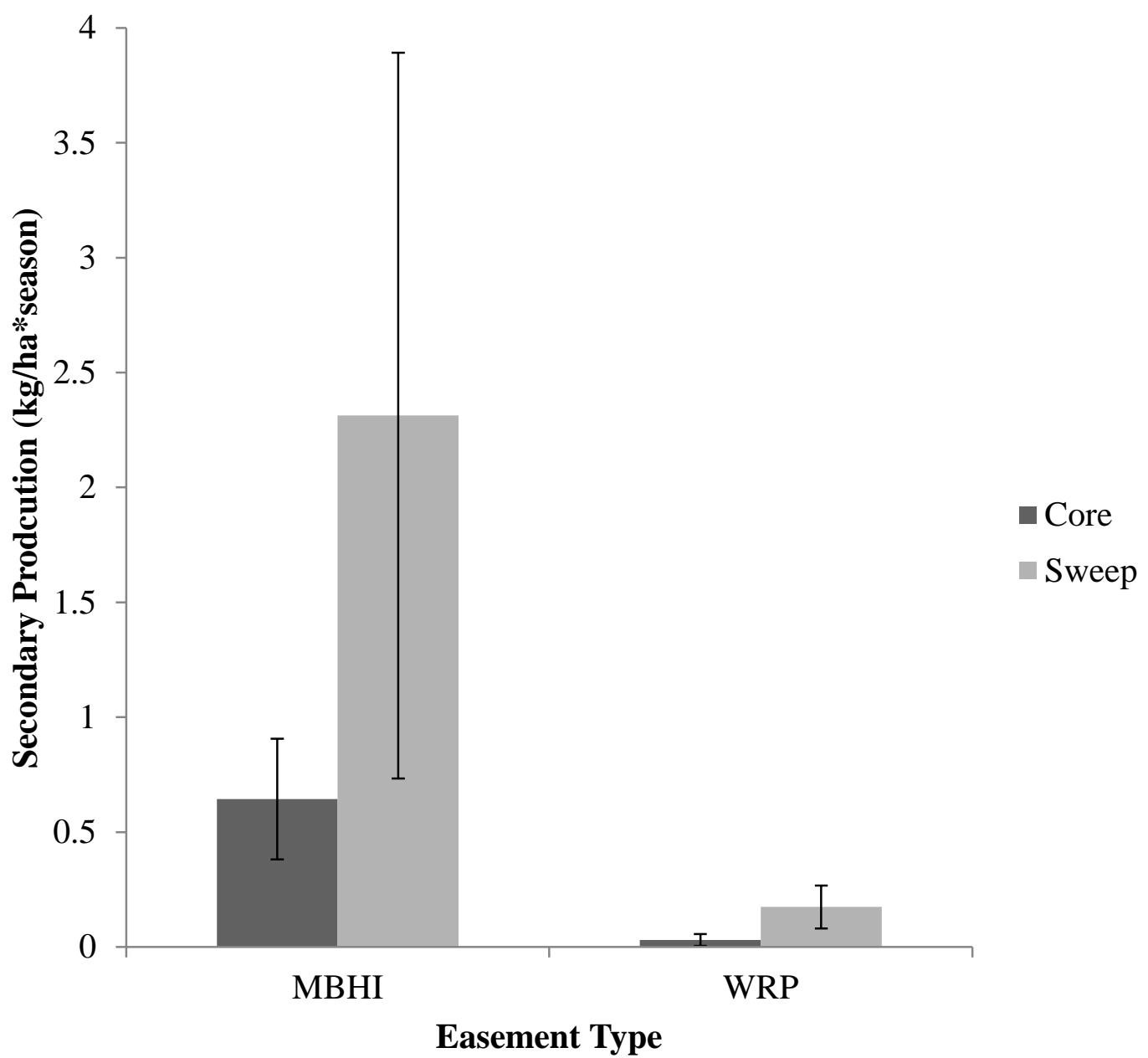

Figure 2.1. Mean ( \pm SE) invertebrate secondary production from benthic core and nektonic sweep samples collected at Migratory Bird Habitat Initiative (MBHI) wetlands $(n=6)$ and Wetland Reserve Program (WRP) wetlands $(n=6)$, in Arkansas and Missouri during autumn 2011. 


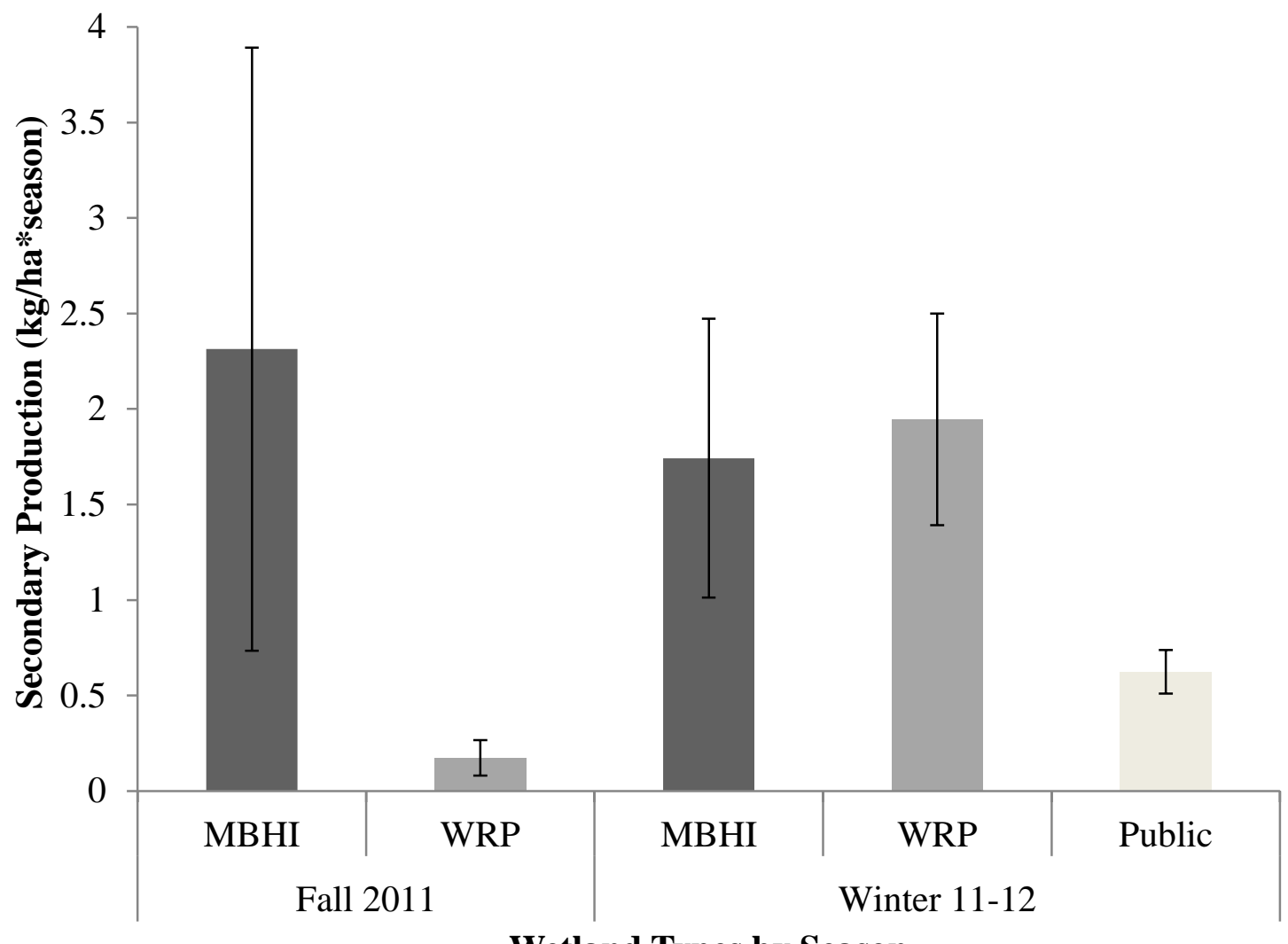

Wetland Types by Season

Figure 2.2. Seasonal invertebrate production based on biweekly sweep samples $(n=601)$ collected at Migratory Bird Habitat Initiative (MBHI) sites $(n=6)$, Wetland Reserve Program (WRP) sites $(n=6)$, and publicly owned wetlands $(n=7)$ in Arkansas and Missouri during autumn 2011 and winter 11-12. Public wetlands in autumn were dry, with one exception, and were omitted from autumn analyses. 


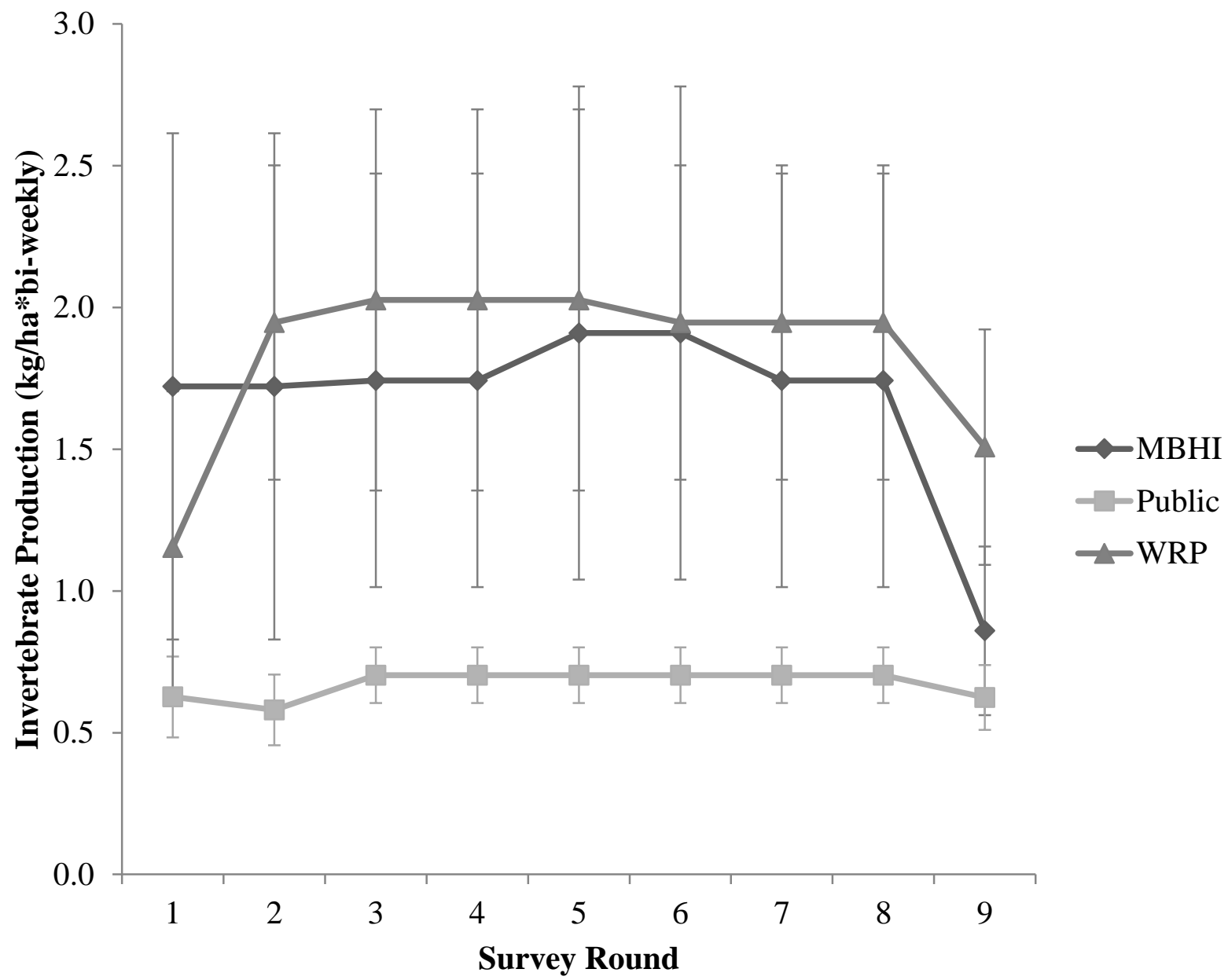

Figure 2.3. Bi-weekly invertebrate secondary production from sweep samples collected at Migratory Bird Habitat Initiative (MBHI) wetlands $(n=6)$, Wetland Reserve Program (WRP) wetlands $(n=6)$, and publicly owned wetlands $(n=7)$ in Arkansas and Missouri during winter 2011-2012. 


\section{CHAPTER III:}

\section{THE INFLUENCE OF LANDSCAPE AND LOCAL HABITAT CONDITIONS ON MIGRATORY WATERBIRD USE OF SEASONAL WETLANDS IN THE LOWER MISSISSIPPI ALLUVIAL VALLEY}

Despite wetland ecosystems having high spatial and temporal heterogeneity due to their variable hydrologic patterns, migratory waterbirds still rely on wetland habitats at migration stopover and wintering sites (Skagan and Knopf 1993). A lack of nonbreeding wetland habitat and food availability can increase the time waterbirds spend meeting the nutritional demands of migration (Newton 2006) and may be detrimental to survival, nest initiation, and breeding success, thereby creating a nutritional bottleneck (Heitmeyer and Fredrickson 1981, Delnicki and Reinecke 1986, Raveling and Heitmeyer 1989, Helmers 1992, Davis and Smith 1998, Anteau and Afton 2004, Drent et al. 2006). For decades, the major objective of regional waterbird conservation strategies was to provide sufficient food habitats in wintering areas to sustain target population numbers (Reinecke et al. 1989, Reinecke and Loesch 1996, Pearse et al. 2012). However, this strategy did not formally address landscape structure, such as wetland distribution, that may influence waterbird distribution, abundances, and community structures (Fairbairn and Dinsmore 2001, Naugle et al. 2001, Webb et al. 2010a, Pearse et al. 2012). The most recent action plan provided by the North American Waterfowl Management Plan (NAWMP) committee recommended identification of the most important areas for waterfowl habitat conservation at a regional scale (NAWMP 2004), prompting the need for a better 
understanding of how waterbirds interact with landscapes to meet their energetic requirements during the nonbreeding season.

The theory of island biogeography has been used to help explain the biological diversity within wetlands, because they are essentially islands within a matrix of terrestrial environments (Brown and Dinsmore 1986, Hall et al. 2004). However, using island biogeography to explain waterbird distribution among wetlands is somewhat flawed because the theory ignores variables within the matrix that may influence immigration to a wetland (Hall et al. 2004). Regardless, studies have demonstrated greater waterbird abundance and species richness in areas with high wetland density, sometimes referred to as wetland complexes (MacArthur and Wilson 1967, Brown and Dinsmore 1986, Fairbairn and Dinsmore 2001, Naugle et al. 2001, Webb et al. 2010a). A wetland complex is often described as a region containing multiple wetlands with varying hydrological, vegetative, and topographical characteristics, capable of providing a greater array of microhabitats for waterbirds compared to more isolated wetlands (Brown and Dinsmore 1986, Fredrickson and Reid 1988, Tori et al. 2002). Implicit in this concept is that birds seek out areas with greater wetland density because isolated wetlands do not contain all of the resources required for survival (Krapu 1974, Dwyer et al. 1979). The influences of landscape-scale factors on migratory waterbird use have mostly been investigated at breeding habitats (Brown and Dinsmore 1986, Fairbairn and Dinsmore 2001, Naugle et al. 2001). However, the wetland complex concept has been adopted by conservation planners and researchers that focus on stopover and wintering areas because of the importance of these regions to waterbird populations (Fredrickson and Reid 1988, Tori et al. 2002, Taft and Haig 2006a, Webb et al. 2010a, Albanese et al. 2012, Pearse et 
al. 2012). For example, Webb et al. (2010) found that spring migrating dabbling ducks at study sites in the Rainwater Basin of Nebraska were influenced by area of wetland habitat within $10 \mathrm{~km}$ of study sites. In contrast, migrating shorebird distributions were best explained by wetland density estimates within $1.5 \mathrm{~km}$ (Albanese et al. 2012).

There is a general lack of information about how waterbirds respond to landscape structure and habitat patterns among spatial scales (Albanese et al 2012), and so our understanding of the relationship between avian use and habitat is often limited to one scale (Wiens 1989). Comprehensive evaluation of migratory waterbird stopover and wintering habitat has already found several local factors within wetlands (i.e. vegetative structure, and inundated area) are related to waterbird use (de Szalay and Resh 1997, Hagy and Kaminski 2012a-b, Fleming et al. 2012, Chapter 1). Still, few researchers have simultaneously monitored food dynamics and avian response (Martin 1995, Percival et al. 1998, Greer et al. 2009, Hagy and Kaminski 2012a-b) and even fewer have included landscape context into similar studies (although see McKinney et al. 2006, Taft and Haig 2006b). Ultimately, studies of waterbird use might not be a reliable indicator of habitat quality when the parameters are limited to a single scale. Waterbird habitat selection during migration and wintering periods may instead be a complex series of decisions that include landscape context, local habitat conditions, predation risk, social status, and energetic requirements (Percival et al. 1998, Nolet et al. 2001, van Gils et al. 2004, Johnson, 2007, Morris and Mukherjee 2007, Castillo-Guerrero et al. 2009, Callicutt et al. 2011, Albanese et al. 2012). Further research directed at modeling migratory waterbird movements is necessary to truly understand wetland connectivity and better design 
conservation strategies, not just for waterbirds but all organisms that benefit from wetland habitats (Haig et al. 1998).

Studies that consider habitat use at multiple spatial scales may be a critical step toward improving regional conservation strategies, especially when the efforts are targeted at highly mobile species such as migratory waterbirds (Taft and Haig 2006b, Callicutt et al. 2011, Albanese et al 2012). The objectives of this study were to: (1) develop models including variables at local, landscape, and a combination of both scales to explain migrating shorebird and wintering dabbling duck abundance and species richness at seasonal wetlands, (2) determine the best fit models for each waterbird response variable, and (3) evaluate implications of my results to conservation of wetland habitats used by migratory waterbirds in the LMAV.

\section{$\underline{\text { Study Area }}$}

Study wetlands were located on conservation easement lands enrolled in the WRP and actively managed public lands in the LMAV of Arkansas and Missouri. This study was part of a larger project evaluating the Migratory Bird Habitat Initiative (MBHI), therefore I stratified potential study wetlands by county, identified the 3 counties containing the greatest number of MBHI contracts within each state, and randomly selected individual WRP easements enrolled in the MBHI within these counties (Stafford et al. 2006, Ratti and Garton 1994). The 3 counties containing the greatest number of MBHI contracts were Lee, Prairie, and St. Francis counties in Arkansas, and Bollinger, Stoddard and New Madrid counties in Missouri. I randomly apportioned 6 MBHI easements (hereafter MBHI) among selected Arkansas and Missouri counties. Similarly, 
I selected 6 reference WRP easements (hereafter WRP) in the same counties that received no additional MBHI funding for implementation of active management practices. I obtained contract information from NRCS district conservationists and landowners and if an easement contained more than one wetland, I randomly selected a single wetland within each easement. As an additional reference, I selected 6 sites on public lands that represented long-term, intensively managed moist-soil wetlands (Duck Creek Conservation Area [1 site] and Mingo National Wildlife Refuge [2 sites] in Missouri; Cache River National Wildlife Refuge [3 sites] in Arkansas).

Area of all private wetlands (MBHI and WRP) ranged from 1.1 - 48.6 ha. Topography, wetland characteristics, and landowner financial resources all varied among sites, which influenced the type and intensity of management techniques, as well as wetland habitat conditions (Chapter 2). All study wetlands except one WRP site had water control structures, which enabled draining or retaining water on wetlands. Area of study wetlands on public lands ranged from 3.4 - 43.2 ha. Water sources for study wetlands originated from rivers, ditches, pumps, runoff, and precipitation. No study wetlands had interconnected hydrology; therefore, wetlands were considered discrete, independent survey and analytical units (Fleming et al 2012). Commonly occurring vegetation in wetlands consisted of native species adapted to seasonal flooding and drainage (moist-soil conditions), including grasses (e.g., Echinochloa spp., Panicum spp.), forbs (Polygonum spp., Bidens spp., Xanthium strumarium), sedges and rushes (Cyperus spp., Juncus spp.), trees and shrubs (Salix nigra), as well as planted agricultural food plots. 


\section{METHODS}

\section{Waterbird Surveys}

I conducted waterbird surveys bi-weekly from 3 August through 16 September 2011 to detect early-autumn migrants and from 3 November 2011 through 24 February 2012 to detect late-autumn migrants and wintering waterbirds. I divided daylight hours into 4 time intervals; sunrise to 0800 hours, 0800-1200 hours, 1200-1600 hours, and 1600 hours to sunset and attempted to conduct bi-weekly surveys at each wetland during a different time interval to reduce any associated temporal biases with bird use (Davis and Smith 1998, Webb et al. 2010a). I followed waterbird survey protocols described in the Integrated Waterbird Management and Monitoring Program's (IWMM) Monitoring Manual (2010) for whole area counts. During autumn surveys, I recorded all waterbird species observed, whereas I recorded only observed waterfowl species during winter surveys. Upon arrival, I recorded all birds visible in open water from vantage points outside the perimeter of the wetland (Webb et al. 2010a). I located and identified individual waterbirds with $8 \times 42$ Eagle Optics ${ }^{\circledR}$ binoculars and a Celestron Ultima ${ }^{\circledR}$ spotting scope with 20-60x zoom. To identify birds in large flocks (>100 birds), I recorded species present and visually estimated the number of each species to the nearest 10. I spent a maximum of 15 minutes at each observation point. Number of observation points per wetland ranged from 1 to 5 and were sufficient to view at least $70 \%$ areal coverage of each wetland. I then drove through and around wetlands in an all-terrain vehicle to enhance detection and identification of birds in densely vegetated areas (Twedt and Nelms 1999, Heitmeyer 2006, Kaminski et al. 2006). When a survey included more than one observation point, I observed where birds flew and alighted after being flushed 
to avoid duplicate bird counts (Kaminski and Prince 1981, Fairbairn and Dinsmore 2001, Webb et al. 2010a).

\section{Habitat Sampling}

Shorebirds have been known to avoid moist-soil wetland habitat with high vertical and horizontal vegetation cover (Clark and Greenwood 1987, Davis and Smith1998). Therefore, during each site visit in autumn, I recorded vegetation height and percent cover along two transects located perpendicular to the shoreline through five water level strata corresponding to shorebird foraging water depths; mudflat (area of sparsely vegetated moist-soil), shallow water $(0-5 \mathrm{~cm}$ depth), moderate-shallow $(5-10 \mathrm{~cm}$ depth), moderate-deep (10-16 cm) and deep water (16 cm+ depth) (Figure 1.3). Each transect was located adjacent to invertebrate sampling locations. I used a $1 \mathrm{~m}^{2}$ frame to quantify vegetation at each water level strata along each transect. I visually estimated percent cover of vegetation in each of the $1 \mathrm{~m}^{2}$ plots (Wirwa 2009). To quantify plant height I measured the height of two randomly selected plants that made up $>10 \%$ of the groundcover within each $1 \mathrm{~m}^{2}$ plot (Webb et al. 2010a). Due to morphological characteristics (e.g., bill length, leg length), shorebirds forage only in portions of wetland habitat within specific water depths (Helmers 1992). To estimate amount of shorebird foraging habitat, I measured the total distance from beginning of mudflat to $16-\mathrm{cm}$ water depth (Davis and Smith 1998) on each transect I selected for vegetation sampling (Figure 1.3). I then delineated total wet area and transect lengths on printed aerial maps of each wetland unit and estimated total wetland area for shorebirds. During winter site visits, I 
visually estimated percent vegetative cover within $1 \mathrm{~m}^{2}$ of each invertebrate sampling location (see below), total percent vegetative cover for each wetland, and total wet area.

\section{Aquatic Invertebrate Sampling}

To assess invertebrate food availability for autumn migrating shorebirds, I collected invertebrate samples at study sites on a bi-weekly basis from August through mid-September. If shorebirds were present during a site visit, I collected invertebrate samples at randomly selected points within the area where I observed the majority of birds within the wetland. If no birds were detected at a site, I sampled and recorded habitat data at randomly selected locations within the dominant vegetative cover in the wetland, excluding any areas with $>50 \%$ vegetative cover to prevent collecting invertebrate samples from microhabitats that were unlikely to be used by shorebirds (Davis and Smith 1998). I also restricted sample collection locations to water depths at which shorebirds were expected to forage (mudflat to $16 \mathrm{~cm}$ water depth). During each site visit, I collected two $5-\mathrm{cm}$ deep x $10-\mathrm{cm}$ diameter soil core samples $\left(392.85 \mathrm{~cm}^{3}\right.$; Sherfy et al. 2000, Hamer et al. 2006, Davis and Bidwell 2008) to quantify benthic invertebrates. I washed soil samples through a $500 \mu \mathrm{m}$ mesh sieve bucket while in the field. I also collected two samples of nektonic invertebrates with a $500 \mu \mathrm{m}$ rectangular sweep net. I lowered the net into the water and dragged it along the bottom for a distance of $1.1 \mathrm{~m}\left(0.5 \mathrm{~m}^{2}\right.$ area) (Wehrle et al. 1995, Gray et al. 1999). Soil core and water-column samples were stored in plastic storage bags with at least $70 \%$ ethanol and returned to the lab for processing (Murkin et al. 1994, Anderson et al. 2000). 
To estimate invertebrate availability for waterfowl during winter I used a rectangular sweep net $(46 \mathrm{~cm} \times 20 \mathrm{~cm} ; 500 \mu \mathrm{m})$ to sample aquatic invertebrates bi-weekly from November through February ( $n=4$ sweeps/site/visit; Wehrle et al. 1995, Hagy and Kaminski 2012a). I stratified sites by dominant cover types: open water $(<50 \%$ vegetative cover) and vegetation (>50\% vegetative cover) and collected 2 sweep samples at random locations within each cover type (Davis and Bidwell 2008). If waterfowl were present, I collected invertebrate samples and habitat data in the general area where the majority of birds were located within the wetland. If no birds were detected at a site, I collected samples at random locations within dominant cover types at water depths which dabbling ducks are capable of foraging (0-60 cm; Dubowy 1988, Isola et al. 2000). Specifically, I vertically lowered the sweep net until it was pushed firmly against the substrate and bounced it along the bottom for $1.0 \mathrm{~m}$ to sample a $0.5 \mathrm{~m}^{2}$ area (Cheal et al. 1993, Gray et al. 1999, Hagy and Kaminski 2012a). I transported each sweep sample in a plastic bag for storage in at least $70 \%$ ethyl alcohol and later added rose bengal to facilitate sorting (Murkin et al. 1994, Anderson et al. 2000).

\section{Moist-soil seed sampling}

Seasonal wetlands can contain more than 50 species of moist-soil plant seeds and tubers, which are an important dietary component for many migrating and wintering dabbling ducks (Gruenhagen and Fredrickson 1990, Kross et al. 2008, Hagy and Kaminski 2012a, Tidwell et al. 2013). I estimated moist-soil seed and tuber biomass by collecting 10 soil core samples at each site twice during late autumn 2011 through winter 2012 (Kross et al. 2008, Evans-Peters et al. 2012, Olmstead et al. 2013). I collected soil 
cores at random locations along a transect within each wetland once in October when a majority of the seeds had dehisced (Reinecke and Hartke 2005, Kross et al. 2008) and once during late February after most waterfowl had migrated north. Previous research (Olmstead 2010, Evans-Peters 2010) reported approximately 90\% of seed biomass from $10 \mathrm{~cm}$ soil samples located in the top $5 \mathrm{~cm}$; therefore, I extracted $5 \mathrm{~cm}$ depth $\mathrm{x} 10 \mathrm{~cm}$ diameter $\left(392.85 \mathrm{~cm}^{3}\right)$ cores at each sampling location (Kross et al. 2008, Greer et al. 2009). After each core was extracted, I placed it in a plastic bag and stored it at $-10^{\circ} \mathrm{C}$ until further processing (Kross et al. 2008, Olmstead et al. 2013).

\section{Sample processing}

To facilitate sorting and identification, I stained invertebrate samples with rose bengal solution for 12-24 hours prior to processing (Sherfy et al 2000, Bolduc and Afton 2003). I filtered samples with running water through a series of sieves of decreasing mesh sizes $(500 \mu \mathrm{m}$ and $100 \mu \mathrm{m})$ to separate samples into coarse and fine samples, and facilitate sorting and identification (Bolduc and Afton 2003). Coarse samples were processed entirely, whereas fine samples were subsampled (1:2 to $1: 32$ of total) using a Folsom plankton splitter (Aquatic Research Instruments) prior to removal of macroinvertebrates (Whiting et al. 2011). The percent composition and biomass in the fine subsample were extrapolated and added to the coarse sample invertebrate abundance and biomass to estimate total fine sample invertebrate abundance and biomass in the overall sample. I catalogued invertebrates by family and reported biomass $(\mathrm{kg} / \mathrm{ha})$ estimates for each taxon (Hagy and Kaminski 2012a). To obtain biomass estimates, I oven-dried specimens at $55^{\circ} \mathrm{C}$ for $\geq 24 \mathrm{~h}$ to a constant mass (to the nearest $0.01 \mathrm{mg}$ ) 
(Anderson and Smith 2000). Secondary production for each family was estimated using the size-frequency method and published annual or seasonal production/biomass $(\mathrm{P} / \mathrm{B})$ ratios for macroinvertebrates (Stagliano and Whiles 2002). According to published protocol, size-specific dry mass was estimated for all resident taxa using length-weight relationships obtained from Benke et al. (1999), Stagliano and Whiles (2002), and EvansWhite et al. (2003). When P/B estimates for families were not available, I used estimates for individual species within that family that have been observed in habitats with similar environmental characteristics. I then calculated total bi-weekly and seasonal production for each study wetland.

I thawed each soil core sample overnight and then soaked the sample for 3-5 hours in a solution of 3\% hydrogen peroxide, to allow for clay dispersion (Hagy and Kaminski 2012b). I washed soil cores through a series of 2 sieves ( \#50 [0.03 mm] and $\# 10[1.65 \mathrm{~mm}])$ to segregate the sample into coarse and fine vegetative matter and dried samples to a constant mass at approximately $87^{\circ} \mathrm{C}$ for $\geq 24$ hours (Kross et al. 2008, Hagy and Kaminski 2012b). I sorted seeds and tubers from the coarse and fine portions and recorded dry mass (to the nearest $.01 \mathrm{mg}$ ). I placed the contents of the fine sieve on grid paper and select one quarter of the sample for sorting and weighing. I multiplied the subsample by 4 ( $25 \%$ sub-sample) and added to the mass of the coarse sample to estimate total dry biomass for each core (Reinecke and Hartke 2005, Kross et al. 2008). I converted seed and tuber biomass for each core to kilograms per hectare (Kross et al. 2008). Seed depletion was calculated by deducting February seed biomass estimates from October seed biomass. 


\section{Landscape-scale variables}

I used ArcGIS 10.0 (Environmental Systems Research Institute 2011) and Fragstats 4.1 to quantify landscape variables based on the 2006 National Land Cover Dataset (NLCD) produced by the U. S. Geological Survey Multi-Resolution Land Characteristics Consortium (MRLC 2013) and a WRP spatial datalayer for Missouri and Arkansas obtained from NRCS. I observed that many WRP easements in the datalayer were not spatially represented in the NLCD because they were indicated as cropland. As an alternative to wetland habitats indicated in the NLCD, I used the WRP spatial datalayer to represent potential available seasonal wetland habitat within the landscape. Wetland landscape structure was quantified in terms of proximity to, percent area of and interspersion indices of WRP easements within selected buffers to determine which metrics of nearby habitats were most important to waterbirds. Spatial scales for autumn shorebird and winter dabbling duck analyses were based on the distance birds fly between wetlands within stopover or wintering areas (Wiens 1989, Webb et al. 2010a, Pearse et al. 2012). For shorebird analyses, I quantified percent WRP easement area and juxtaposition within $1.5 \mathrm{~km}$ of study wetlands (Table 3.1; Albanese et al. 2012). For dabbling duck analyses, I quantified percent WRP easement area and juxtaposition within $3.5 \mathrm{~km}$ and $10 \mathrm{~km}$ of study wetlands (Table 3.1; Fredrickson and Reid 1988, Webb et al. 2010a, Beatty et al. In review). Because waterfowl also rely on agricultural waste grains as a food source during winter (Baldassare et al. 1983, Stafford et al. 2006, Pearse et al. 2012), I used the NLCD datalayer to quantify percent cropland area and juxtaposition within each buffer for dabbling duck analyses. I also calculated the proximity (km) from the center of each study wetland to the nearest WRP easement. 
Model selection and data analysis

I analyzed data from each season separately because of differences in environmental conditions, sampling methodologies, and avian community composition (Chapter 1). I converted autumn invertebrate biomass (kg/ha) and production ( $\mathrm{kg} / \mathrm{ha} / \mathrm{season}$ ) to densities by using total shorebird foraging habitat (ha) estimates. I converted winter invertebrate and seed variables to densities by dividing by total wet area. I modeled shorebird and dabbling duck abundance instead of density because I wanted to evaluate wetland area as a habitat characteristic in the models, as wetland area is often used as a metric for conservation and management goals (McKinney et al. 2006). The relationship between dabbling duck use and percent vegetative cover within wetlands is often nonlinear (Weller and Spatcher 1965, Murkin et al. 1982, Smith et al. 2004, Webb et al. 2010a); therefore I squared the percent cover variable to produce a linear relationship. To facilitate model convergence, I centered and standardized all explanatory variables using two standard deviations (Gelman 2008). Local and landscape characteristics that were highly correlated $(r>0.6)$ were not included in models (McKinney et al. 2006). Specifically, invertebrate production was positively correlated with invertebrate biomass during winter $(r=0.60, p<0.01)$ and excluded from winter models. Preliminary models also included aggregation indices, however, several aggregation indices were highly correlated with WRP easement juxtaposition and percent area (all $\mathrm{r}>0.62, \mathrm{p}<0.01)$, and thus were excluded from all models. All tests were conducted using SAS/STAT ${ }^{\circledR} 9.2$, and $\alpha=0.05$ significance level (SAS Institute 2012). 
I developed 3 sets of models a priori to explain abundance and species richness of migrating shorebirds and wintering dabbling ducks; local models, landscape models and combined (local and landscape factors) models (Table 3.2, Table 3.3). Local models were developed based on environmental characteristics within wetlands known to influence shorebird and dabbling duck abundance and community composition. For instance, dense vegetation inhibits shorebird foraging activities, so the majority of shorebird use occurs at wetlands with less than 25 percent cover (Helmers 1992, Colwell and Dodd 1997, Twedt et al. 1998). In addition, shorter vegetation is thought to increase shorebird visibility of surrounding horizons for predator detection (Metcalfe 1984, Davis and Smith1998, DeLeon and Smith 1999, Webb et al. 2010a). Vegetative cover has also been shown to be a predictor of dabbling duck abundance during migration, with the greatest dabbling duck abundance in wetlands with approximately 50\% vegetation (Smith et al. 2004, Webb et al. 2010a). Food production is thought to play a part in determining waterbird use of wetlands during nonbreeding seasons (Murkin and Kadlec 1986; Helmers 1992; Krapu and Reinecke 1992, Skagen and Knopf 1993, Safran et al.1997; Ashley et al. 2000, Hagy and Kaminski 2012a, Pearse et al. 2012) therefore local models also included estimates of invertebrate biomass and production (shorebird and dabbling duck models), as well as moist-soil seed biomass and depletion obtained from study wetlands (dabbling duck models only).

Landscape models were constructed using aforementioned variables extracted from landscape data layers and included proximity to, juxtaposition and percent area of WRP easements (shorebird and dabbling duck models), as well as juxtaposition and area of agricultural lands (dabbling duck models only) (Pearse et al. 2012; Table 3.2, Table 
3.3). Wetland habitat at the $1.5 \mathrm{~km}$ scale best predicted shorebird occurrence patterns at wetland habitats during migration in north-central Oklahoma (Albanese et al. 2012), which is an agriculturally dominated landscape similar to the LMAV (King et al. 2006). For dabbling duck analyses, I quantified wetlands and croplands within two buffers, $3.5 \mathrm{~km}$ and $10 \mathrm{~km}$ of study wetlands, due to observed behavioral differences between species (Fredrickson and Reid 1988, Cox and Davis 2005, Webb et al. 2010a, Beatty et al. In review). Another set of models was created to test the hypothesis that a combination of landscape and local variables will explain a greater amount of variability in bird use metrics than landscape or local predictors alone (Table 3.2, Table 3.3). I used an information theoretic approach to evaluate a priori models predicting shorebird and dabbling duck abundance, as well as species richness (Burnham and Anderson 2002) using the general linear mixed model procedure (PROC GLIMMIX; SAS Institute 2012). I used a natural log transformation on each response variable to obtain a normal distribution (Zar 1999). To account for temporal variation in response and local predictor variables, I included study site as a random effect. For each response variable, I fit models using maximum likelihood estimation and calculated output statistics including second order Akaike's Information Criterion $\left(\mathrm{AIC}_{\mathrm{c}}\right)$ values, and model weights $\left(w_{\mathrm{i}}\right)$ for the null model (containing only wet area and the random effect) and all candidate models (Burnham and Anderson 2002). I also assessed the fit of all candidate models by calculating adjusted partial $\mathrm{R}^{2}$ values (Nagelkerke 1991). Models with $\Delta \mathrm{AIC}_{\mathrm{c}}$ values less than 2 were considered best fit models (Richards 2005). I then averaged best fit models for each response variable using a natural averaging method described by Symonds and Moussalli (2011). 


\section{RESULTS}

From 3 August through 16 September I conducted 85 avian surveys and observed 13 shorebird species (432 individuals) at 9 study wetlands. Drought conditions combined with landowner reluctance to flood sites until winter resulted in approximately $50 \%$ of study sites being completely dry during almost the entire autumn survey period. Approximately $99 \%$ of the shorebirds species observed were comprised of killdeer (Charadrius vociferous, 48\%), least sandpipers (Calidris minutilla, 14\%), black-necked stilts (Himantopus mexicanus, 12\%), greater yellowlegs (Tringa melanoleuca, 10\%), solitary sandpipers (Tringa solitaria, 4\%), Wilson's snipe (Gallinago delicata, 4\%), semipalmated sandpipers (Calidris pusilla, 4\%), Baird's sandpipers (Calidris bairdii, $2 \%$ ), and pectoral sandpipers (Calidris melanotos, 1\%). Mean bi-weekly shorebird abundance was $4.2( \pm 1.2)$ birds per site, and mean species richness was $1.9( \pm 0.5)$ species per site (Table 3.4). I collected 85 total invertebrate samples to quantify autumn shorebird food availability. Mean bi-weekly invertebrate biomass was $35.9( \pm 7.9) \mathrm{kg} / \mathrm{ha}$ per site and invertebrate production was $946.0( \pm 484.6) \mathrm{kg} / \mathrm{ha} / \mathrm{bi}$-weekly per site (Table $3.4)$.

I conducted 330 wintering waterfowl surveys at 18 wetlands from 3 November 3 2011 through 24 February 2012. I observed 33,418 waterfowl and recorded 20 waterfowl species with $94 \%$ of total birds consisting of mallards (Anas platyrhynchos, 60\%), Northern shovelers (A. cylpeata, 13\%), gadwall (A. strepera, 8\%), green-winged teal (A. crecca, 5\%), ring-necked ducks (Aythya collaris, 5\%), and Northern pintails (A. acuta, 3\%). Mean bi-weekly waterfowl abundance was $98.4( \pm 26.7)$ birds per site, and species 
richness averaged $0.3( \pm 0.1)$ species per site (Table 3.4). I collected a total of 516 winter invertebrate samples and 360 seed samples to quantify dabbling duck food availability. Mean bi-weekly invertebrate biomass was $4.0( \pm 0.5) \mathrm{kg} / \mathrm{ha}$, seasonal seed production was $313.2( \pm 19.0) \mathrm{kg} / \mathrm{ha}$, and seed depletion was $38.4( \pm 2.1)$ (Table 3.4).

Most landscape variables exhibited less variation $( \pm$ SE) than local predictors (Table 3.4). Mean percent WRP area within $1.5 \mathrm{~km}$ of study wetlands was $3.3( \pm 0.3)$, and was over 2 times greater within $3.5 \mathrm{~km}$ of study wetlands (15.8 [ \pm 1.1$])$ compared to percent WRP area within 10km $(6.5[ \pm 0.2])$. Percent juxtaposition of WRP wetlands was greatest within $1.5 \mathrm{~km}$ of study wetlands $(52.6 \pm[3.3])$, followed by $10 \mathrm{~km}(49.2[ \pm$ $0.2])$ and $3.5 \mathrm{~km}(43.6[ \pm 1.3])$ buffers. Percent cropland within $10 \mathrm{~km}$ buffers $(54.3[ \pm$ 1.7]) was approximately 1.5 times greater than within $3.5 \mathrm{~km}$ buffers (36.9 [ \pm 1.6$])$. Percent juxtaposition of croplands was similar between $3.5 \mathrm{~km}(66.2[ \pm 0.7])$ and $10 \mathrm{~km}$ buffers $(59.0[ \pm 0.4])$.

The best approximating models for both shorebird abundance and species richness contained only wetland area (null models) and accounted for $39 \%$ and $41 \%$ of the model weights, respectively (Table 3.5). Juxtaposition of WRP within $1.5 \mathrm{~km}$ (-) of study sites was the top variable in competing models and accounted for $34 \%$ of the model weights for abundance and $29 \%$ for species richness. Adjusted $R^{2}$ estimates for WRP juxtaposition as a predictor of shorebird abundance $\left(R^{2}\right.$ of 0.14$)$ and species richness $\left(R^{2}\right.$ of 0.12) indicated that these models held similar, but limited explanatory power (Table 3.5). Model averaged parameter estimates indicate that while wetland area was not an important predictor of abundance (Figure 3.1a), it was likely an important predictor of shorebird species richness (Figure 3.1b). Additionally, juxtaposition of WRP was not an 
important predictor of either shorebird response variables. Variables in the remaining models were not supported by the data and accounted for $\leq 8 \%$ of the model weights for either response variable.

A model containing a combination of local and landscape variables was the best fit model in explaining dabbling duck abundance (Table 3.6). Specifically, local food abundance, including invertebrate biomass (-), seed biomass (+), and seed depletion (-), percent vegetative cover (-), and cropland juxtaposition within 10km (+) were all components in the dabbling duck model that accounted for $62 \%$ of the model weights. Model averaged parameter estimates indicated that wetland area, seed biomass, \% cover, and cropland juxtaposition within 10km were important predictors of dabbling duck abundance (Figure 3.2a). Variables in the remaining models were not supported by the abundance data and accounted for $14 \%$ or less of the model weights.

There were ten best fit models for dabbling duck species richness, including the null model $\left(\Delta \mathrm{AIC}_{\mathrm{c}}=1.13\right)$. These models contained the variables percent cover $(-)$, cropland area within 10km (-), WRP area within 10km (-), and cropland juxtaposition within $10 \mathrm{~km}(+)$. Based on model averaged parameter estimates, none of the variables in the best approximating models were important predictors of species richness (Figure 3.2b). In addition, all adjusted $R^{2}$ estimates for these models were less than 0.04 , indicating little explanatory power (Table 3.6). The null model did not rank among the best fit models for dabbling duck species richness $\left(\Delta \mathrm{AIC}_{\mathrm{c}}=17.4\right)$ and variables in the remaining models explaining species richness accounted for $4 \%$ or less of model weights.

\section{DISCUSSION}


Wetlands are a conservation priority in numerous areas because of the great diversity of organisms they support and the decrease in both extent and ecosystem function due to anthropogenic activities (King et al. 2006, King et al. 2009, Pearse et al. 2012). Many migratory waterbirds are wetland obligates for most or all of their life cycle and have varying habitat and energetic requirements that can be met primarily in wetland habitats (Haig et al. 1998). Therefore, it is important for regional conservation planners and land managers to know what environmental indicators are important to these birds and how to efficiently manage available habitats. In this study, I investigated whether the combination of landscape and local variables explained a greater amount of variability in waterbird use than individual landscape or local characteristics.

Shorebird abundance and species richness during autumn 2011 was best explained by wetland area (null model). However parameter estimate confidence intervals indicate that wetland area was not an important predictor of shorebird abundance and had a negative influence on shorebird species richness. This could be for a variety of reasons but perhaps including all shorebird species, which have distinct foraging strategies and habitat requirements (Helmers 1992, Davis and Smith 1998, Hamer et al. 2006, Smith et al. 2012), obscured some of the effects of wetland area on shorebird abundance and species richness. Furthermore, the most abundant shorebird species I observed was killdeer, who also occur and forage within various upland habitat types (Jackson and Jackson 2000) and as a habitat generalist, may not have responded to individual wetland or landscape variables (Taft and Haig 2006).

In addition to wetland area, WRP juxtaposition within $1.5 \mathrm{~km}$ was another likely model explaining shorebird metrics. However, WRP juxtaposition was not an important 
predictor. Taft and Haig (2006) found that wetland landscape structure was only an important predictor of shorebird use during years with limited precipitation and wetland habitat availability. Indeed, Arkansas and Missouri experienced moderate drought conditions during autumn 2011 (NOAA 2012) and many landowners with pumping capabilities did not initiate wetland inundation until waterfowl season (mid-November), which resulted in $50 \%$ of study wetlands being completely dry during the shorebird survey period. As a consequence, estimates of WRP area and proximity may not have been accurate indicators of actual habitat availability across the landscape and reduced sample size may have impeded my ability to detect an influence of WRP juxtaposition.

Models that explained winter dabbling duck use also included a combination of local and landscape variables. Dabbling duck abundance was best predicted by a single model that included all local variables (invertebrate and seed metrics and percent vegetation cover) and cropland juxtaposition within 10km. Based on parameter estimates for the all local and cropland juxtaposition model, dabbling ducks were using seasonal wetlands that contained greater wetland area and moderate vegetative cover. Many studies of have documented that vegetation structure is a key factor influencing waterbird use of wetlands because of its influence on food availability, foraging activities, and ability to provide cover (Weller and Spatcher 1965, Murkin et al. 1982, Davis and Smith 1998, Gray et al. 1999, Fairbairn and Dinsmore 2001, Smith et al. 2004, Davis and Bidwell 2008, Webb et al. 2010a). Wetlands with greater dabbling duck abundances also had greater abundant local wetland foods (at least moist-soil seeds) with several agricultural fields nearby, indicating a reliance on natural and anthropogenic food sources. Land use in the LMAV is currently dominated by agricultural operations and 
because waterfowl exhibit opportunistic foraging behaviors, waste grains make up a large portion of their winter diet (Reinecke et al 1989, Stafford et al. 2006, Callicutt et al. 2011, Pearse et al. 2012). Juxtaposition of flooded croplands also positively influenced wintering dabbling duck abundances in Mississippi (Pearse et al. 2012). While I was not able to distinguish between flooded and non-flooded croplands among the geospatial data layer, I believe that my results are representative of actual dabbling duck abundances because of the similarity of landscape composition throughout much of the LMAV.

Model estimates indicated a negative relationship between dabbling duck abundance and invertebrate biomass. The relative importance of invertebrates as a dietary component for dabbling ducks can vary temporally (within season), by species, and by age and sex (Miller 1987, Heitmeyer 1988, Reinecke et al. 1989, Richardson and Kaminski 1992, Anderson et al. 2000), and may render invertebrate biomass a poor predictor of habitat use by all dabbling ducks. Furthermore, previous studies in the LMAV found that mallards (Anas platyrhynchos) consume relatively small amounts of invertebrates $(<12 \%$ dry mass) compared to plant materials (Gruenhagen and Fredrickson 1990, Combs and Fredrickson 1996), and may not actively seek out invertebrates to meet protein requirements during most of winter.

Variables in models explaining species richness included percent cover, cropland and WRP area within 10km, cropland and WRP juxtaposition within 10km, and WRP area within $3 \mathrm{~km}$. The associations between these variables and species richness were mostly negative and were not important predictors, providing counterintuitive and confounding results. While I did not analyze individual species responses to local and landscape predictors because of limited sample size, the lack of important local and 
landscape predictors in explanatory models may be a consequence of species specific responses to broad-scale habitat cues (Cox and Davis 2005, McKinney et al. 2006, Webb et al. 2010a, Pearse et al. 2011). Also, these associations could be a consequence of ecological interactions with other species (competition) or disturbance (DuBowy 1988, Helmers 1992, Skagen and Knopf 1994, Davis and Smith 1998, Pease et al. 2005, Webb et al. 2010b), neither of which I quantified.

Although portions of my results align with previous research (Taft and Haig 2006, Albanese et al. 2012, Pearse et al. 2012), my models only accounted for a small proportion of the total variation in waterbird abundance and species richness (all $R^{2} \leq$ 0.18). Low R-squared values indicate that my models may be lacking important predictor variables (Nagelkerke 1991). I only included WRP wetlands as potential habitat within the landscape, and so the absence of public wetlands from my analyses might account for some of the unexplained variation in waterbird use (Beatty et al. In Review). In addition, it was not always feasible to conduct avian surveys to coincide with when optimal waterbird densities were expected to be observed ( 3 hours after sunrise and 3 hours before sunset; Hagy and Kaminski 2012a), so I randomized waterbird survey times at each site visit. Shorebirds and waterfowl have also been known to feed at night (Dodd and Colwell 1996, Anderson and Smith 1999), but I was unable to observe nocturnal waterbird use at my study wetlands. Failure to survey sites at times when waterbirds were most likely to be present and/or foraging may have reduced my ability to model variation within my response variables.

Despite the lack of explanatory power from my models, model weights suggest that more variation in waterbird responses was explained by models including multiple 
spatial scales. The combination of local (within wetlands) and landscape features within the model explaining dabbling duck abundance fundamentally supports a predominant theory used to describe the process of stopover site selection used by neotropical migrants. The theory proposes that these long-distance migrants initially seek broadscale habitat indicators and advance toward finer-scale characteristics (Simons et al. 2000; Taft and Haig 2006, Deppe and Rotenberry 2008, Albanese et al. 2012). In reality, the stopover site selection strategy probably shifts among years with precipitation and habitat availability (Taft and Haig 2006). The data from my research encompasses a single season for each group of waterbirds and variation in results across years is expected. Further research investigating how waterbirds, as individuals and as an avian community, interact with habitat at larger spatial and temporal scales during nonbreeding periods can better facilitate wetland conservation and management efforts in the LMAV (Wiens 1989, Haig et al. 1998, Albanese et al. 2012).

\section{MANAGEMENT IMPLICATIONS}

Conservation of wetland complexes may be paramount to ensuring adequate stopover and wintering resources are consistently present and available within landscapes that are constantly being altered by anthropogenic influences. Ideally, stopover and wintering sites contain many different wetland types with varying hydroperiods, thus providing habitat for each group of waterbirds when they are present within the region (Webb et al. 2010). Semi-permanent wetlands, which can remain inundated for up to a few years at a time, and other persistent aquatic habitats may be an important alternative to seasonal wetlands for shorebird habitat in dry years. In agriculture-dominated landscapes such as the LMAV, conservation programs that promote winter flooding of 
croplands adjacent to important wetland habitats may be an efficient method of providing additional habitats for dabbling ducks. Management at broader spatial scales will likely require private landowner support and a fundamental understanding of how individual wetlands are incorporated into complexes to provide sufficient habitat for migratory waterbirds.

For decades, wetland managers have been encouraged to include landscape variables when developing plans for habitat management. Fredrickson and Reid (1998) suggested that public land managers should consider all wetlands within a 10 -mile radius as the wetland complex when estimating total resources for waterfowl. In some states, private land coordinators use wetland distribution in the surrounding landscape to help rank potential conservation sites, such as Wetland Reserve Program (WRP) enrollments. Successful enrollments receive financial and technical assistance for restoration and management activities (NRCS 2013a). Up to $19 \%$ of the ranking to establish which lands in Arkansas are enrolled is determined by proximity to conservation areas and contiguous forest (King et al. 2006). Private land coordinators in Missouri use a wetland habitat appraisal guide (WHAG), which scores WRP applicants on land use types such as nonforested wetland and cropland within 2 miles of each potential easement (Kevin Dacey, personal communication, January 25, 2012). According to my results, landscape composition should be considered as an important component in the ranking of potential WRP easements in the LMAV. 


\section{LITERATURE CITED}

Albanese, G., C. A. Davis, and B. W. Compton. 2012. Spatiotemporal scaling of North American continental interior wetlands: implications for shorebird conservation. Landscape Ecology 27:1465-1479.

Anderson, J. T. and L. M. Smith. 1998. Protein and energy production in playas: Implications for migratory bird management. Society of Wetland Scientists 18:437-446.

Anderson, J. T. and L. M. Smith. 2000. Invertebrate response to moist-soil management of playa wetlands. Ecological Applications 10:550-558.

Anderson, J. T., L. M. Smith, and D. A. Haukos. 2000. Food selection and feather molt by nonbreeding American green-winged teal in Texas playas. The Journal of Wildlife Management 64:222-230.

Andren, H. 1994. Effects of habitat fragmentation on birds and mammals in landscapes with different proportions of suitable habitat: a review. Oikos 71:355-366.

Anteau, M. J., A. D. Afton, and D. Haukos. 2004. Nutrient reserves of lesser scaup (Aythya affinis) during spring migration in the Mississippi flyway: a test of the spring condition hypothesis. The Auk 121:917-929

Ashley, M. C., J. A. Robinson, L. W. Oring, and G. A. Vinyard. 2000. Dipteran standing stock biomass and effects of aquatic bird predation at a constructed wetland. Wetlands 20:84-90.

Baldassarre, G. A., R. J. Whyte, E. E. Quinlan, and E. G. Bolen. 1983. Dynamics and quality of waste corn available to postbreeding waterfowl in Texas. Wildlife Society Bulletin 11:25-31.

Batzer, D. P. and A. Ruhí. 2013. Is there a core set of organisms that structure macroinvertebrate assemblages in freshwater wetlands? Freshwater Biology 58:1647-1659.

Beatty, W. S., E. B. Webb, D. C. Kesler, A. H. Raedeke, L. W. Naylor, and D. D. Humburg. Landscape effects on waterbird habitat selection at multiple scales during the non-breeding season. In review.

Benke, A. C., A. D. Huryn, L. A. Smock, and J. B. Wallace. 1999. Length-mass relationships for freshwater macroinvertebrates in North America with particular reference to the southeastern United States. Journal of the North American Benthological Society 18:308-343. 
Bolduc, F. and A. D. Afton. 2003. Effects of structural marsh management and salinity on invertebrate prety of waterbirds in marsh ponds during winter on the Gulf Coast Chenier Plain. Wetlands 23:897-910.

Brown, M. and J. J. Dinsmore. 1986. Implications of marsh size and isolation for marsh bird management. The Journal of Wildlife Management 50:392-397.

Buler, J. J., M. L. Sieges, and J. A. Smolinsky. 2013. Assessment of Bird Response to the NRCS Migratory Bird Habitat Initiative using Weather Surveillance Radar: Final Report. Department of Entomology and Wildlife Ecology, University of Delaware, Newark, DE.

Burnham, K. P. and D. R. Anderson. 2002. Model selection and multi-model inference: a practical information-theoretic approach. Second edition. Springer-Verlag, New York, New York, USA.

Callicutt, J. T., H. M. Hagy, and M. L. Schummer. 2011. The Food Preference Paradigm: A Review of Autumn-Winter Food Use by North American Dabbling Ducks (1900-2009). Journal of Fish and Wildlife Management 2:29-40.

Castillo-Guerrero, J. A., G. Fernández, G. Arellano, and E. Mellink. 2009. Diurnal abundance, foraging behavior and habitat use by non-breeding Marbled Godwits and Willets at Guerrero Negro, Baja California Sur, México. Waterbirds 32:400407.

Cheal, F., J. Davis, J. Growns, J. Bradley, and F. Whittles. 1993. The influence of sampling method on the classification of wetland macroinvertebrate communities. Hydrobiologia 257:47-56.

Clark, R. G. and H. Greenwood. 1987. A circular" ring-angel" movement by fieldfeeding waterfowl. Wilson Bulletin 99:722-723.

Colwell, M. A. and S. L. Dodd. 1997. Environmental and habitat correlates of pasture use by nonbreeding shorebirds. Condor 99:337-344.

Cox Jr, R. and B. Davis. 2005. Habitat use, movements, and survival of female northern pintails during spring migration in Nebraska and subsequent potential breedingsite selection in the Prairie Pothole Region. Progress Report. US Geological Survey, Northern Prairie Wildlife Research Center, Jamestown, North Dakota, USA.

Davis, B. E. and A. D. Afton. 2010. Movement distances and habitat switching by female mallards wintering in the Lower Mississippi alluvial valley. Waterbirds 33:349356. 
Davis, C. A. and J. R. Bidwell. 2008. Response of aquatic invertebrates to vegetation management and agriculture. Wetlands 28:793-805.

Davis, C. A. and L. M. Smith. 1998. Ecology and management of migrant shorebirds in the Playa Lakes Region of Texas. Wildlife Monographs 140:1-45

DeLeon, M. T. and L. M. Smith. 1999. Behavior of migrating shorebirds at North Dakota prairie potholes. Condor 101:645-654.

Delettre, Y. R. and N. Morvan. 2000. Dispersal of adult aquatic Chironomidae (Diptera) in agricultural landscapes. Freshwater Biology 44:399-411.

Delnicki, D. and K. J. Reinecke. 1986. Mid-winter food use and body weights of mallards and wood ducks in Mississippi. Journal of Wildlife Management 50:43-51.

Deppe, J. L. and J. T. Rotenberry. 2008. Scale-dependent habitat use by fall migratory birds: vegetation structure, floristics, and geography. Ecological Monographs 78:461-487.

de Szalay, F. A. and V. H. Resh. 1997. Responses of wetland invertebrates and plants important in waterfowl diets to burning and mowing of emergent vegetation. Wetlands 17:149-156.

Dodd, S. L. and M. A. Colwell. 1996. Seasonal variation in diurnal and nocturnal distributions of nonbreeding shorebirds at North Humboldt Bay, California. Condor 98:196-207.

Drent, R. H. 2006. The timing of birds' breeding seasons: the Perrins hypothesis revisited especially for migrants. Ardea 94:305-322.

DuBowy, P. J. 1988. Waterfowl communities and seasonal environments: temporal variability in interspecific competition. Ecology 69:1439-1453.

Dwyer, T. J., G. L. Krapu, and D. M. Janke. 1979. Use of prairie pothole habitat by breeding mallards. The Journal of Wildlife Management 43:526-531.

Evans-Peters, G. R., B. D. Dugger, and M. J. Petrie. 2012. Plant Community Composition and Waterfowl Food Production on Wetland Reserve Program Easements Compared to Those on Managed Public Lands in Western Oregon and Washington. Wetlands 32:391-399.

Evans-White, M. A., W. K. Dodds, and M. R. Whiles. 2003. Ecosystem significance of crayfishes and stonerollers in a prairie stream: functional differences between cooccurring omnivores. Journal of the North American Benthological Society 22:423-441. 
Fairbairn, S. E. and J. J. Dinsmore. 2001. Local and landscape-level influences on wetland bird communities of the prairie pothole region of Iowa, USA. Wetlands 21:41-47.

Fleming, K. S., R. M. Kaminski, T. E. Tietjen, M. L. Schummer, G. N. Ervin, and K. D. Nelms. 2012. Vegetative Forage Quality and Moist-soil Management on Wetlands Reserve Program Lands in Mississippi. Wetlands 32:919-929.

Fredrickson, L. and F. Reid. 1986. Wetland and riparian habitats: a nongame management overview. Pages 59-96 in J. B. Hale, L. B. Best, and R. L. Clawson, editors. Management of nongame wildlife in the Midwest: a developing art, North Central Section of The Wildlife Society, Chelsea, Michigan.

Fredrickson, L. H. and F. A. Reid. 1988. "Waterfowl Use of Wetland Complexes." in U. S. F. a. W. S. U.S. Department of the Interior, editor. Waterfowl Management Handbook, Fort Collins, Colorado.

Fredrickson, L. H. and T. S. Taylor. 1982. Management of seasonally flooded impoundments for wildlife. U. S. Fish and Wildlife Service, Resource Publication 148.

Gelman, A. 2008. Scaling regression inputs by dividing by two standard deviations. Statistics in medicine 27:2865-2873.

Gray, R. L. and B. M. Teels. 2006. Wildlife and fish conservation through the Farm Bill. Wildlife Society Bulletin 34:906-913.

Gray, M. J., R. M. Kaminski, G. Weerakkody, B. D. Leopold, and K. C. Jensen. 1999. Aquatic invertebrate and plant responses following mechanical manipulations of moist-soil habitat. Wildlife Society Bulletin 27:770-779.

Greer, D. M., B. D. Dugger, K. J. Reinecke, and M. J. Petrie. 2009. Depletion of rice as food of waterfowl wintering in the Mississippi Alluvial Valley. The Journal of Wildlife Management 73:1125-1133.

Gruenhagen, N. M. and L. H. Fredrickson. 1990. Food use by migratory female mallards in Northwest Missouri. The Journal of Wildlife Management 54:622-626.

Hall, D. L., M. R. Willig, D. L. Moorhead, R. W. Sites, E. B. Fish, and T. R. Mollhagen. 2004. Aquatic macroinvertebrate diversity of playa wetlands: the role of landscape and island biogeographic characteristics. Wetlands 24:77-91.

Haig, S. M., D. W. Mehlman, and L. W. Oring. 1998. Avian movements and wetland connectivity in landscape conservation. Conservation Biology 12:749-758. 
Hagy, H. M. and R. M. Kaminski. 2012a. Apparent seed use by ducks in moist-soil wetlands of the Mississippi Alluvial Valley. The Journal of Wildlife Management 76:1053-1061.

Hagy, H. M. and R. M. Kaminski. 2012b. Winter waterbird and food dynamics in autumn-managed moist-soil wetlands in the Mississippi Alluvial Valley. Wildlife Society Bulletin 36:512-523.

Hamer, G. L., E. J. Heske, J. D. Brawn, and P. W. Brown. 2006. Migrant shorebird predation on benthic invertebrates along the Illinois river, Illinois. . The Wilson Journal of Ornithology 188:152-163.

Haukos, D. A. and L. M. Smith. 1995. Chemical composition of seeds from plants in playa wetlands. Wildlife Society Bulletin 23:514-519.

Heitmeyer, M. E. 1988. Protein costs of prebasic molt in female mallards. Condor 90:263-266.

Heitmeyer, M. E. 2006. The importance of winter floods to mallards in the Mississippi Alluvial Valley. Journal of Wildlife Management 70:101-110.

Heitmeyer, M. E. and L. H. Fredrickson. 1981. Do wetland conditions in the Mississippi Delta hardwoods influence Mallard recruitment. Pages 44-57 in North American Wildlife and Natural Resources Conference.

Helmers, D. L. 1992. Shorebird management manual. Western Hemisphere Shorebird Reserve Network, Manomet, Massachusetts.

Integrated Waterbird Management and Monitoring Program [IWMM]. 2010. Integrated waterbird management and monitoring program of the Atlantic and Mississippi Flyways, habitat quality sub-team, waterfowl workshop summary proposal. Laurel, Maryland: Patuxent Wildlife Research Center.

Isola, C., M. Colwell, O. Taft, and R. Safran. 2000. Interspecific differences in habitat use of shorebirds and waterfowl foraging in managed wetlands of California's San Joaquin Valley. Waterbirds 23:196-203.

Jackson, B. J. S. and J. A. Jackson. 2000. Killdeer (Charadrius vociferus). In A. Poole and F. Gill, editors. The Birds of North America. The Birds of North America, Inc, Philadelphia, PA.

Johnson, M. D. 2007. Measuring habitat quality: a review. The Condor 109:489-504.

Kaminski, R. M., G. A. Baldassarre, and A. T. Pearse. 2006. Waterbird responses to hydrological management of Wetlands Reserve Program habitats in New York. Wildlife Society Bulletin 34:921-926. 
Kaminski, R. M. and H. H. Prince. 1981. Dabbling duck and aquatic macroinvertebrate responses to manipulated wetland habitat. The Journal of Wildlife Management 45:1-15.

King, S. L. and B. D. Keeland. 1999. Evaluation of reforestation in the lower Mississippi River alluvial valley. Restoration Ecology 7:348-359.

King, S. L., D. J. Twedt, and R. R. Wilson. 2006. The role of the Wetland Reserve Program in conservation efforts in the Mississippi Alluvial Valley. The Wildlife Society Bulletin 34:914-920.

King, S. L., R. R. Sharitz, J. W. Groninger, and L. L. Battaglia. 2009. The ecology, restoration, and management of southeastern floodplain ecosystems: A synthesis. Wetlands 29:624-634.

Krapu, G. L. 1974. Feeding ecology of pintail hens during reproduction. The Auk 91:278-290.

Krapu, G. L. and K. J. Reinecke. 1992. Foraging ecology and nutrition. Pages 1-29 in Ecology and Management of Breeding Waterfowl. University of Minnesota Press, Minneapolis, MN, USA.

Kross, J., R. M. Kaminski, K. J. Reinecke, E. J. Penny, and A. T. Pearse. 2008. MoistSoil Seed Abundance in Managed Wetlands in the Mississippi Alluvial Valley. The Journal of Wildlife Management 72:707-714.

Link, P. T., A. D. Afton, R. R. Cox Jr, and B. E. Davis. 2011. Daily Movements of Female Mallards Wintering in Southwestern Louisiana. Waterbirds 34:422-428.

MacArthur, R. H., and E. O. Wilson. 1967. The theory of island biogeography. Princeton University Press, Princeton, New Jersey, USA.

McKinney, R. A., S. R. McWilliams, and M. A. Charpentier. 2006. Waterfowl-habitat associations during winter in an urban North Atlantic estuary. Biological Conservation 132:239-249.

Metcalfe, N. B. 1984. The effects of habitat on the vigilance of shorebirds: is visibility important? Animal Behaviour 32:981-985.

Miller, M. R. 1987. Fall and winter foods of northern pintails in the Sacramento Valley, California. The Journal of Wildlife Management 51:405-414.

Morris, D. W. and S. Mukherjee. 2007. Can we measure carrying capacity with foraging behavior? Ecology 88:597-604. 
Multi-Resolution Land Characteristics Consortium. 2013. 2006 National Land Cover Data. http://www.epa.gov/mrlc/nlcd-2006.html. Accessed 2013 September 16.

Murkin, H. R., D. A. Wrubleski, and F. Reid. 1994. Sampling invertebrates in aquatic and terrestrial habitats. Pages 349-369 in T. A. Bookhout, editor. Research and Management Techniques for Wildlife and Habitats. The Wildlife Society, Bethesda, MD, USA.

Murkin, H. R. and J. A. Kadlec. 1986. Responses by benthic macroinvertebrates to prolonged flooding of marsh habitat. Canadian Journal of Zoology 64:65-72.

Murkin, H. R., R. M. Kaminski, and R. D. Titman. 1982. Responses by dabbling ducks and aquatic invertebrates to an experimentally manipulated cattail marsh. Canadian Journal of Zoology 60:2324-2332.

Nagelkerke, N. J. 1991. A note on a general definition of the coefficient of determination. Biometrika 78:691-692.

Naugle, D. E., R. R. Johnson, M. E. Estey, and K. F. Higgins. 2001. A landscape approach to conserving wetland bird habitat in the prairie pothole region of eastern South Dakota. Wetlands 21:1-17.

Natural Resources Conservation Service. 2013a. Wetlands Reserve Program. http://www.nrcs.usda.gov/wps/portal/nrcs/main/national/programs/easements/wetl ands/ Accessed 2013 June 27.

Natural Resources Conservation Service. 2013b. Migratory Bird Habitat Initiative. https://prod.nrcs.usda.gov/wps/portal/nrcs/detailfull/national/programs/farmbill/in itiatives/?cid=steldevb1027669/ Accessed 2013 June 27.

National Oceanic and Atmospheric Administration (NOAA). 2012. "Climate Prediction Center - Monitoring \& Data: Drought Monitoring." http://www.cpc.ncep.noaa.gov/products/monitoring_and_data/drought.shtml. Accessed 2013 July 08.

Newton, I. 2006. Can conditions experienced during migration limit the population levels of birds? Journal of Ornithology 147:146-166.

Nolet, B. A., O. Langevoord, R. M. Bevan, K. R. Engelaar, M. Klaassen, R. J. Mulder, and S. Van Dijk. 2001. Spatial variation in tuber depletion by swans explained by differences in net intake rates. Ecology 82:1655-1667.

North American Waterfowl Management Plan, Plan Committee. 2004. North American Waterfowl Management Plan 2004. Implementation Framework: Strengthening the Biological Foundation. Canadian Wildlife Service, U.S. Fish and Wildlife Service, Secretaria de Medio Ambiente y Recursos Naturales, 106 pp. 
Olmstead, V. G., E. B. Webb, and R. W. Johnson. 2013. Moist-Soil Seed Biomass and Species Richness on Wetland Reserve Program Easements in the Mississippi Alluvial Valley. Wetlands 33:1-10.

Pearse, A. T., G. L. Krapu, R. R. Cox Jr, and B. E. Davis. 2011. Spring-migration ecology of Northern Pintails in south-central Nebraska. Waterbirds 34:10-18.

Pearse, A. T., G. L. Krapu, R. R. Cox Jr, and B. E. Davis. 2011. Spring-migration ecology of Northern Pintails in south-central Nebraska. Waterbirds 34:10-18.

Pearse, A. T., R. M. Kaminski, K. J. Reinecke, and S. J. Dinsmore. 2012. Local and landscape associations between wintering dabbling ducks and wetland complexes in Mississippi. Wetlands 32:859-869.

Pease, M. L., R. K. Rose, and M. J. Butler. 2005. Effects of human disturbances on the behavior of wintering ducks. Wildlife Society Bulletin 33:103-112.

Percival, S., W. Sutherland, and P. Evans. 1998. Intertidal habitat loss and wildfowl numbers: applications of a spatial depletion model. Journal of Applied Ecology 35:57-63.

Ratti, J. T. and E. O. Garton. 1994. Research and experimental design. Pages 1-23 in T. A. Bookhout, editor. Research and management techniques for wildlife and habitats. Fifth edition. The Wildlife Society, Bethesda, Maryland, USA.

Raveling, D. G. and M. E. Heitmeyer. 1989. Relationships of population size and recruitment of pintails to habitat conditions and harvest. Journal of Wildlife Management 53:1088-1103.

Reinecke, K. J. and K. M. Hartke. 2005. Research Notes: Estimating Moist-soil Seeds Available to Waterfowl with Double Sampling for Stratification. Journal of Wildlife Management 69:794-799.

Reinecke, K. J., R. M. Kaminski, D. J. Moorehead, J. D. Hodges, and J. R. Nassar. 1989. Mississippi Alluvial Valley. Pages 203-247 in L. M. Smith, R. L. Pederson, and R. M. Kaminski, editors. Habitat management for migrating and wintering waterfowl in North America. Texas Tech University Press, Lubbock, USA.

Reinecke, K. and C. Loesch. 1996. Integrating research and management to conserve wildfowl (Anatidae) and wetlands in the Mississippi Alluvial Valley, USA. Gibier Faune Sauvage 13:927-940.

Richards, S. A. 2005. Testing ecological theory using the information-theoretic approach: examples and cautionary results. Ecology 86:2805-2814. 
Richardson, D. M. and R. M. Kaminski. 1992. Diet restriction, diet quality, and prebasic molt in female mallards. The Journal of Wildlife Management 56:531-539.

Safran, R. J., C. R. Isola, M. A. Colwell, and O. E. Williams. 1997. Benthic invertebrates at foraging locations of nine waterbird species in managed wetlands of the northern San Joaquin Valley, California. Wetlands 17:407-415.

Sherfy, M. H., R. L. Kirkpatrick, and K. D. Richkus. 2000. Benthos core sampling and chironomid vertical distribution: implications for assessing shorebird food availability. Wildlife Society Bulletin 28:124-130.

Simons, T. R., S. M. Pearson, and F. R. Moore. 2000. Application of spatial models to the stopover ecology of trans-Gulf migrants. Studies in Avian Biology 20:4-14.

Skagen, S. K. and F. L. Knopf. 1993. Toward Conservation of Midcontinental Shorebird Migrations. Conservation Biology 7:533-541.

Skagen, S. K. and F. L. Knopf. 1994. Migrating shorebirds and habitat dynamics at a prairie wetland complex. The Wilson Bulletin 106:91-105.

Smith, L. M., D. A. Haukos, and R. M. Prather. 2004. Avian response to vegetative pattern in playa wetlands during winter. Wildlife Society Bulletin 32:474-480.

Stafford, J. D., R. M. Kaminski, K. J. Reinecke, and S. W. Manley. 2006. Waste rice for waterfowl in the Mississippi Alluvial Valley. Journal of Wildlife Management 70:61-69.

Stagliano, D. M. and M. R. Whiles. 2011. Macroinvertebrate production and trophic structure in a tallgrass prairie headwater stream. Journal of the North American Benthological Society 21:97-113.

Symonds, M. R. and A. Moussalli. 2011. A brief guide to model selection, multimodel inference and model averaging in behavioural ecology using Akaike's information criterion. Behavioral Ecology and Sociobiology 65:13-21.

Taft, O. W. and S. M. Haig. 2006. Landscape context mediates influence of local food abundance on wetland use by wintering shorebirds in an agricultural valley. Biological Conservation 128:298-307.

Tidwell, P. R., E. B. Webb, M. P. Vrtiska, and A. A. Bishop. 2013. Diets and Food Selection of Female Mallards and Blue-Winged Teal During Spring Migration. Journal of Fish and Wildlife Management 4:63-74.

Twedt, D. J. and C. O. Nelms. 1999. Waterfowl density on agricultural fields managed to retain water in winter. Wildlife Society Bulletin 27:924-930. 
Twedt, J. D., C. O. Nelms, V. E. Rettig, and S. R. Aycock. 1998. Shorebird use of managed wetlands in the Mississippi Alluvial Valley. The American Midland Naturalist 140:140-152.

Tori, G. M., S. McLeod, K. McKnight, T. Moorman, and F. A. Reid. 2002. Wetland conservation and Ducks Unlimited: real world approaches to multispecies management. Waterbirds 25:115-121.

Van Gils, J. A., P. Edelaar, G. Escudero, and T. Piersma. 2004. Carrying capacity models should not use fixed prey density thresholds: a plea for using more tools of behavioural ecology. Oikos 104:197-204.

Webb, E. B., L. M. Smith, M. P. Vrtiska, and T. G. Lagrange. 2010. Effects of local and landscape variables on wetland bird habitat use during migration through the Rainwater Basin. The Journal of Wildlife Management 74:109-119.

Wehrle, B. W., R. M. Kaminski, B. D. Leopold, and W. P. Smith. 1995. Aquatic invertebrate resources in Mississippi forested wetlands during winter. Wildlife Society Bulletin 23:774-783.

Weller, M. W. and C. S. Spatcher. 1965. Role of habitat in the distribution and abundance of marsh birds. Agricultural and Home Economic Experiment Station, Iowa State University of Science and Technology, Ames, Iowa, USA.

Whiting, D. P., M. R. Whiles, and M. L. Stone. 2011. Patterns of macroinvertebrate production, trophic structure, and energy flow along a tallgrass prairie stream continuum. Limnology and Oceanography 56:887-898.

Wiens, J. A. 1989. Spatial scaling in ecology. Functional ecology 3:385-397.

Wirwa, D. W. 2009. Waterbird use of Kentucky reservoir mudflats. University of Tennessee-Knoxville, Knoxville, Tennessee, USA.

Zar, J. H. 1999. Biostatistical analysis. Prentice Hall, Upper Saddle River, New Jersey, USA. 
Table 3.1. Local (within study wetlands) and landscape variables that were used to construct models that describe the use of seasonal wetlands by autumn migrating shorebirds ( $n=9$ wetlands) and wintering dabbling ducks ( $n=18$ wetlands) within the Mississippi valley of Arkansas and Missouri, August-September 2011 and November 2011-February 2012.

\begin{tabular}{|c|c|c|}
\hline Response variable & Predictor variable & Acronym \\
\hline Shorebirds & $\begin{array}{l}\text { Local } \\
\text { Invertebrate production } \\
\text { Invertebrate biomass } \\
\text { Vegetation height within shorebird habitat } \\
\% \text { vegetation cover within shorebird habitat } \\
\text { Area of wetland available to shorebirds (ha); 0- } \\
18 \mathrm{~cm} \text { water depth }\end{array}$ & $\begin{array}{l}\text { invert_pro } \\
\text { invert_bio } \\
\text { vegheight } \\
\text { cover } \\
\text { wet_area }\end{array}$ \\
\hline & $\begin{array}{l}\text { Landscape } \\
\text { Proximity to nearest WRP easement } \\
\% \text { area of WRP easements within } 1.5 \mathrm{~km} \\
\text { Juxtaposition of WRP easements within } 1.5 \mathrm{~km}\end{array}$ & $\begin{array}{l}\text { wrp_dist } \\
\text { wrp_area1km } \\
\text { wrp_ji_1km }\end{array}$ \\
\hline Dabbling ducks & $\begin{array}{l}\text { Local } \\
\text { Invertebrate biomass } \\
\text { Seed biomass } \\
\text { Seed depletion } \\
\% \text { vegetation cover of entire inundated area } \\
\text { Total inundated area within the perimeter of the } \\
\text { wetland } \\
\text { Landscape } \\
\text { Proximity to nearest WRP easement } \\
\% \text { area of WRP easements within } 3.5 \mathrm{~km} \\
\text { Juxtaposition of WRP easements within } 3.5 \mathrm{~km} \\
\% \text { area of croplands within } 3.5 \mathrm{~km} \\
\text { Juxtaposition of croplands within } 3.5 \mathrm{~km} \\
\% \text { area of WRP easements within } 10 \mathrm{~km} \\
\text { Juxtaposition of WRP easements within } 10 \mathrm{~km} \\
\% \text { area of croplands within } 10 \mathrm{~km} \\
\text { Juxtaposition of croplands within } 10 \mathrm{~km}\end{array}$ & $\begin{array}{l}\text { wrp_dist } \\
\text { wrp_area3km } \\
\text { wrp_ji_3km } \\
\text { ag_area3km } \\
\text { ag_ji_3km } \\
\text { wrp_area10km } \\
\text { wrp_ji_10km } \\
\text { ag_area10km } \\
\text { ag_ji_10km }\end{array}$ \\
\hline
\end{tabular}


Table 3.2. Local (within study wetlands), landscape and combined models created to describe the use of seasonal wetlands ( $n=9$ wetlands) by autumn migrating shorebirds within the Mississippi valley of Arkansas and Missouri, AugustSeptember 2011 .

\begin{tabular}{|c|c|c|}
\hline & Model Name & Model $^{\mathbf{a}}$ \\
\hline \multirow[t]{3}{*}{ Local } & Food & invert_pro + invert_bio + wet_area \\
\hline & Habitat & vegheight + cover + wet_area \\
\hline & All local & invert_pro + invert_bio + vegheight + cover + wet_area \\
\hline \multirow{3}{*}{$\begin{array}{l}\text { Landscape } \\
1.5 \mathrm{~km} \\
\text { radius }\end{array}$} & WRP proximity & wrp_dist + wet_area \\
\hline & WRP area $1.5 \mathrm{~km}$ & wrp_area1km + wet_area \\
\hline & WRP juxtaposition $1.5 \mathrm{~km}$ & wrp_ji_1km + wet_area \\
\hline \multirow[t]{9}{*}{ Combined } & Food and WRP proximity & invert_pro + invert_bio + wrp_dist + wet_area \\
\hline & Habitat and WRP proximity & vegheight + cover + wrp_dist + wet_area \\
\hline & All local and WRP proximity & invert_pro + invert_bio + vegheight, + cover + wrp_dist + wet_area \\
\hline & Food and WRP area $1.5 \mathrm{~km}$ & invert_pro + invert_bio + wrp_area1km + wet_area \\
\hline & Habitat and WRP area $1.5 \mathrm{~km}$ & vegheight + cover + wrp_area1km + wet_area \\
\hline & All local and WRP area $1.5 \mathrm{~km}$ & $\begin{array}{l}\text { invert_pro + invert_bio + vegheight, + cover + wrp_area1 km + } \\
\text { wet_area }\end{array}$ \\
\hline & Food and WRP juxtaposition $1.5 \mathrm{~km}$ & invert_pro + invert_bio + wrp_ji_1km + wet_area \\
\hline & $\begin{array}{l}\text { Habitat and WRP juxtaposition } \\
1.5 \mathrm{~km}\end{array}$ & vegheight + cover + wrp_ji_1 km + wet_area \\
\hline & $\begin{array}{l}\text { All local and WRP juxtaposition } \\
1.5 \mathrm{~km}\end{array}$ & $\begin{array}{l}\text { invert_pro + invert_bio + vegheight, + cover + wrp_ji_1km + } \\
\text { wet_area }\end{array}$ \\
\hline
\end{tabular}

${ }^{a}$ All models contain wet_area as a covariate. Parameter acronyms are described in Table 3.1. 
Table 3.3. Local (within study wetlands) and landscape $(3.5 \mathrm{~km}$ and $10 \mathrm{~km}$ radius) predictor variables that were used to construct models that describe the use of seasonal wetlands ( $n=18$ wetlands) by wintering dabbling ducks within the Mississippi valley of Arkansas and Missouri, November 2011-February 2012.

\begin{tabular}{|c|c|c|}
\hline Scale & Model Name & Model $^{\mathbf{a}}$ \\
\hline \multirow[t]{5}{*}{ Local } & Inverts & invert_bio + wet_area \\
\hline & Seeds & seed_bio + seed_dep + wet_area \\
\hline & All food & invert_bio + seed_bio + seed_dep + wet_area \\
\hline & Habitat & cover $^{2}+$ wet_area \\
\hline & All Local & invert_bio + seed_bio + seed_dep + vegheight + cover $^{2}+$ wet_area \\
\hline Landscape & WRP proximity & wrp_dist + wet_area \\
\hline \multirow[t]{4}{*}{$3.5 \mathrm{~km}$ radius } & WRP area $3.5 \mathrm{~km}$ & wrp_area3km + wet_area \\
\hline & $\mathrm{AG}$ area $3.5 \mathrm{~km}$ & ag_area3km + wet_area \\
\hline & WRP juxtaposition $3.5 \mathrm{~km}$ & wrp_ji_3km + wet_area \\
\hline & AG juxtaposition $3.5 \mathrm{~km}$ & ag_ji_3km + wet_area \\
\hline \multirow[t]{4}{*}{$10 \mathrm{~km}$ radius } & WRP area $10 \mathrm{~km}$ & wrp_area10km + wet_area \\
\hline & $\mathrm{AG}$ area $10 \mathrm{~km}$ & ag_area10km + wet_area \\
\hline & WRP juxtaposition $10 \mathrm{~km}$ & wrp_ji_10km + wet_area \\
\hline & AG juxtaposition $10 \mathrm{~km}$ & ag_ji_10km + wet_area \\
\hline \multirow[t]{3}{*}{ Combined } & Food and WRP proximity & invert_bio + seed_bio + seed_dep + wrp_dist + wet_area \\
\hline & Habitat and WRP proximity & cover $^{2}+$ wet_area + wrp_dist \\
\hline & All local and WRP proximity & invert_bio + seed_bio + seed_dep + cover $^{2}+$ wet_area + wrp_dist \\
\hline \multirow[t]{2}{*}{$3.5 \mathrm{~km}$ radius } & Food and WRP area $3.5 \mathrm{~km}$ & invert_bio + seed_bio + seed_dep + wrp_area3km + wet_area \\
\hline & Habitat and WRP area $3.5 \mathrm{~km}$ & vegheight + cover $^{2}+$ wet_area + wrp_area3km \\
\hline
\end{tabular}


All local and WRP area $3.5 \mathrm{~km}$

Food and AG area $3.5 \mathrm{~km}$

Habitat and AG area $3.5 \mathrm{~km}$

All local and AG area $3.5 \mathrm{~km}$

Food and WRP juxtaposition $3.5 \mathrm{~km}$

Habitat and WRP juxtaposition $3.5 \mathrm{~km}$

All local and WRP juxtaposition $3.5 \mathrm{~km}$

Food and AG juxtaposition $3.5 \mathrm{~km}$

Habitat and AG juxtaposition $3.5 \mathrm{~km}$

All local and AG juxtaposition $3.5 \mathrm{~km}$

$10 \mathrm{~km}$ radius Food and WRP area 10km

Habitat and WRP area $10 \mathrm{~km}$

All local and WRP area 10km

Food and AG area $10 \mathrm{~km}$
Habitat and AG area $10 \mathrm{~km}$

All local and AG area $10 \mathrm{~km}$

Food and WRP juxtaposition 10km

Habitat and WRP juxtaposition 10km

All local and WRP juxtaposition 10km

Food and AG juxtaposition 10km

Habitat and AG juxtaposition 10km

All local and AG juxtaposition 10km invert_bio + seed_bio + seed_dep + cover $^{2}+$ wet_area + wrp_area $3 \mathrm{~km}$

invert_bio + seed_bio + seed_dep + ag_area $3 \mathrm{~km}$

vegheight + cover $^{2}+$ wet_area + ag_area3 $\mathrm{km}$

invert_bio + seed_bio + seed_dep + cover $^{2}+$ wet_area + ag_area $3 \mathrm{~km}$

invert_bio + seed_bio + seed_dep + wrp_ji_3km + wet_area

vegheight + cover $^{2}+$ wet_area + wrp_ji_3km

invert_bio + seed_bio + seed_dep + cover $^{2}+$ wet_area + wrp_ji_3 km

invert_bio + seed_bio + seed_dep + ag_ji_3km

vegheight + cover $^{2}+$ wet_area + ag_ji_3km

invert_bio + seed_bio + seed_dep + cover $^{2}+$ wet_area + ag_ji_3km

invert_bio + seed_bio + seed_dep + wrp_area10km

vegheight + cover $^{2}+$ wet_area + wrp_area10km

invert_bio + seed_bio + seed_dep + cover $^{2}+$ wet_area + wrp_area $10 \mathrm{~km}$

invert_bio + seed_bio + seed_dep + ag_area10km

vegheight + cover $^{2}+$ wet_area + ag_area $10 \mathrm{~km}$

invert_bio + seed_bio + seed_dep + cover $^{2}+$ wet_area + ag_area $10 \mathrm{~km}$

invert_bio + seed_bio + seed_dep + wrp_ji_10km + wet_area

vegheight + cover $^{2}+$ wet_area + wrp_ji_10km

invert_bio + seed_bio + seed_dep + cover $^{2}+$ wet_area + wrp_ji_10km

invert_bio + seed_bio + seed_dep + ag_ji_10km

vegheight + cover $^{2}+$ wet_area + ag_ji_10km

invert_bio + seed_bio + seed_dep + cover $^{2}+$ wet_area + ag_ji_10km

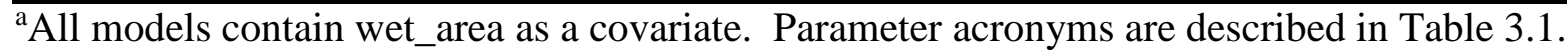


Table 3.4. Mean ( \pm SE) local and landscape predictors and waterbird responses among seasonal wetlands during autumn (August-September 2011; $n=9$ ) and winter (November 2011-February 2012; $n=18$ ) in the Mississippi valley of Arkansas and Missouri.

\begin{tabular}{|c|c|c|c|c|}
\hline \multirow[t]{2}{*}{ Parameters $^{\mathrm{a}}$} & \multicolumn{2}{|c|}{ Autumn 2011} & \multicolumn{2}{|c|}{ Winter 2011-2012 } \\
\hline & Mean \pm SE & Range & Mean $\pm \mathrm{SE}$ & Range \\
\hline \multicolumn{5}{|l|}{ Local predictors } \\
\hline invert_bio (kg/ha) & $35.9 \pm 7.9$ & $2.5-149.4$ & $4.0 \pm 0.5$ & $0.0-60.3$ \\
\hline invert_pro (kg/ha/season) & $946.0 \pm 484.6$ & $0.0-10227.2$ & $170.6 \pm 20.9$ & $0.0-1720.7$ \\
\hline seed_bio $(\mathrm{kg} / \mathrm{ha})$ & -- & -- & $313.2 \pm 19.0$ & $33.8-1021.3$ \\
\hline seed_dep (\%) & -- & -- & $38.4 \pm 2.1$ & $4.2-98.6$ \\
\hline cover $(\%)$ & $23.1 \pm 5.2$ & $0.0-89.4$ & $36.6 \pm 2.3$ & $0.0-99.0$ \\
\hline vegheight (cm) & $16.1 \pm 3.5$ & $0.0-48.9$ & -- & -- \\
\hline wet_area (ha) & $2.8 \pm 0.7$ & $0.2-8.8$ & $10.3 \pm 0.9$ & $0.1-48.6$ \\
\hline \multicolumn{5}{|l|}{ Landscape predictors } \\
\hline wrp_dist $(\mathrm{km})$ & $1.0 \pm 0.3$ & $0.4-5.9$ & $1.6 \pm 0.1$ & $0.1-5.9$ \\
\hline wrp_area1km (\%) & $3.3 \pm 0.3$ & $0.0-4.9$ & -- & -- \\
\hline wrp_ji_1km (\%) & $52.6 \pm 3.3$ & $0.0-67.8$ & -- & -- \\
\hline wrp_area3km (ha) & -- & -- & $15.8 \pm 1.1$ & $0.0-45.7$ \\
\hline wrp_ji_3km (\%) & -- & -- & $43.6 \pm 1.3$ & $0.0-67.7$ \\
\hline wrp_area10km (ha) & -- & -- & $6.5 \pm 0.2$ & $0.3-19.4$ \\
\hline wrp_ji_10km (\%) & -- & -- & $49.2 \pm 0.2$ & $43.2-55.7$ \\
\hline ag_area3km (ha) & -- & -- & $36.9 \pm 1.6$ & $11.9-85.6$ \\
\hline ag_ji_3km $(\%)$ & -- & -- & $66.2 \pm 0.7$ & $49.0-83.2$ \\
\hline ag_area10km (ha) & -- & -- & $54.3 \pm 1.7$ & $19.5-91.2$ \\
\hline ag_ji_10km (\%) & -- & -- & $59.0 \pm 0.4$ & $44.9-72.1$ \\
\hline \multicolumn{5}{|l|}{ Response variables } \\
\hline Shorebird abundance (\# birds) & $4.2 \pm 1.2$ & $0.0-20.0$ & -- & -- \\
\hline $\begin{array}{l}\text { Shorebird species richness } \\
\text { (species/ha) }\end{array}$ & $1.9 \pm 0.5$ & $0.0-8.3$ & -- & -- \\
\hline Dabbling ducks (\# birds) & -- & -- & $98.4 \pm 26.7$ & $0.0-4014.0$ \\
\hline $\begin{array}{l}\text { Dabbling duck species richness } \\
\text { (species/ha) }\end{array}$ & -- & -- & $0.3 \pm 0.1$ & $0.0-4.9$ \\
\hline
\end{tabular}

${ }^{a}$ Parameter acronyms are described in Table 3.1. 
Table 3.5. Results of best fit general linear mixed model regressions with model parameter estimates, number of parameters $(K)$, Akaike's Information Criterion $\left(\mathrm{AIC}_{c}\right), \Delta \mathrm{AIC}_{c}$, and $\mathrm{AIC}_{c}$ weights $\left(w_{i}\right)$ used to rank models containing factors hypothesized to predict total shorebird abundance and species richness at seasonal wetlands ( $n=9$ wetlands) in the Mississippi valley of Arkansas and Missouri, August-September 2011. Models with lower AIC $\mathrm{And}_{c}$ AIC $\mathrm{Al}_{c}$ had more substantial support. Adjusted $R^{2}$ values are reported for comparison.

\begin{tabular}{|c|c|c|c|c|c|c|c|c|c|c|}
\hline $\begin{array}{l}\text { Shorebird } \\
\text { Response }\end{array}$ & Model names & $\begin{array}{l}\text { Model } \\
\text { Parameters }^{\mathrm{a}}\end{array}$ & $\begin{array}{c}\text { Parameter } \\
\text { estimate }( \pm \text { SE) }\end{array}$ & $\begin{array}{c}t- \\
\text { value }\end{array}$ & $\begin{array}{c}\text { F- } \\
\text { value }\end{array}$ & $\begin{array}{c}P- \\
\text { value }\end{array}$ & $K$ & $\Delta \mathrm{AIC}_{\mathrm{c}}{ }^{\mathrm{b}}$ & $w_{i}$ & $\begin{array}{c}\text { Model } \\
\text { Adjusted } \\
R^{2}\end{array}$ \\
\hline \multirow[t]{3}{*}{ Abundance } & Null model & wet_area & $-0.12 \pm 0.50$ & -0.24 & 0.06 & 0.81 & 4 & 0 & 0.39 & -- \\
\hline & $\begin{array}{l}\text { WRP juxtaposition } \\
1.5 \mathrm{~km}\end{array}$ & wrp_ji_1km & $-0.81 \pm 0.44$ & -1.85 & 3.42 & 0.09 & 5 & 0.29 & 0.34 & 0.14 \\
\hline & & wet_area & $-0.27 \pm 0.46$ & -0.58 & 0.33 & 0.58 & -- & -- & -- & -- \\
\hline \multirow[t]{3}{*}{ Richness } & Null model & wet_area & $-0.85 \pm 0.30$ & -2.88 & 8.28 & 0.0139 & 4 & 0 & 0.41 & -- \\
\hline & $\begin{array}{l}\text { WRP juxtaposition } \\
1.5 \mathrm{~km}\end{array}$ & wrp_ji_1km & $-0.45 \pm 0.25$ & -1.79 & 3.2 & 0.01 & 5 & 0.68 & 0.29 & 0.12 \\
\hline & & wet_area & $-0.98 \pm 0.27$ & -3.69 & 13.62 & 0.0031 & -- & -- & -- & -- \\
\hline
\end{tabular}

${ }^{a}$ Null model contains wet_area as a covariate. Models $(n=15)$ are described in Table 3.3, acronyms are described in Table 3.1.

${ }^{\mathrm{b}} \Delta \mathrm{AIC}_{c}=\mathrm{AIC}_{c i}-\mathrm{AIC}_{c}$ min. Min. for abundance $=69.53$; Min. for richness $=45.41$. 
Table 3.6. Results of best fit general linear mixed model regressions with model parameter estimates, number of parameters

$(K)$, Akaike's Information Criterion $\left(\mathrm{AIC}_{\mathrm{c}}\right), \Delta \mathrm{AIC}_{\mathrm{c}}$, and $\mathrm{AIC}_{\mathrm{c}}$ weights $\left(w_{i}\right)$ used to rank models containing factors hypothesized to predict total dabbling duck abundance and species richness at seasonal wetlands ( $n=18$ wetlands) in the Mississippi valley of Arkansas and Missouri, November 2011-February 2012. Models with lower AIC $\mathrm{c}_{\mathrm{c}}$ and $\Delta \mathrm{AIC}_{\mathrm{c}}$ had more substantial support. Adjusted $R^{2}$ values are reported for comparison.

\begin{tabular}{|c|c|c|c|c|c|c|c|c|c|c|}
\hline $\begin{array}{l}\text { Dabbling } \\
\text { duck } \\
\text { Response } \\
\end{array}$ & Model Names & $\begin{array}{l}\text { Model } \\
\text { Parameters }^{\mathrm{a}}\end{array}$ & $\begin{array}{c}\text { Parameter } \\
\text { estimate }( \pm \mathrm{SE})\end{array}$ & $\begin{array}{c}t- \\
\text { value }\end{array}$ & $\begin{array}{c}F- \\
\text { value }\end{array}$ & $\begin{array}{c}P- \\
\text { value }\end{array}$ & $K$ & $\Delta \mathrm{AIC}_{\mathrm{c}}^{\mathrm{b}}$ & $w_{i}$ & $\begin{array}{c}\text { Model } \\
\text { Adjusted } \\
R^{2} \\
\end{array}$ \\
\hline \multirow[t]{6}{*}{ Abundance } & $\begin{array}{l}\text { All local and AG juxtaposition } \\
10 \mathrm{~km}\end{array}$ & invert_bio & $-0.16 \pm 0.36$ & -0.45 & 0.2 & 0.654 & 9 & 0 & 0.62 & 0.18 \\
\hline & & seed_bio & $2.46 \pm 0.50$ & 4.89 & 23.91 & $<.0001$ & -- & -- & -- & -- \\
\hline & & seed_dep & $0.54 \pm 0.52$ & 1.04 & 1.07 & 0.303 & -- & -- & -- & -- \\
\hline & & cover $^{2}$ & $-0.84 \pm 0.35$ & -2.36 & 5.58 & 0.02 & -- & -- & -- & -- \\
\hline & & ag_ji_10km & $2.28 \pm 0.55$ & 4.15 & 17.26 & $<.0001$ & -- & -- & -- & -- \\
\hline & & wet_area & $2.47 \pm 0.53$ & 4.69 & 22 & $<.0001$ & -- & -- & -- & -- \\
\hline \multirow[t]{8}{*}{ Richness } & Habitat and $\mathrm{AG}$ area $10 \mathrm{~km}$ & cover $^{2}$ & $-0.05 \pm 0.03$ & -1.73 & 2.98 & 0.087 & 6 & 0 & 0.09 & 0.04 \\
\hline & & ag_area10km & $-0.10 \pm 0.06$ & -1.63 & 2.65 & 0.106 & -- & -- & -- & -- \\
\hline & & wet_area & $-0.04 \pm 0.06$ & -0.71 & 0.51 & 0.477 & -- & -- & -- & -- \\
\hline & Habitat and WRP area $10 \mathrm{~km}$ & cover $^{2}$ & $-0.06 \pm 0.03$ & -1.82 & 3.32 & 0.071 & 6 & 0.26 & 0.08 & 0.04 \\
\hline & & wrp_area10km & $-0.10 \pm 0.07$ & -1.5 & 2.26 & 0.136 & -- & -- & -- & -- \\
\hline & & wet_area & $-0.01 \pm 0.06$ & -0.19 & 0.04 & 0.846 & -- & -- & -- & -- \\
\hline & Habitat & cover $^{2}$ & $-0.05 \pm 0.03$ & -1.74 & 3.03 & 0.084 & 5 & 0.28 & 0.08 & 0.02 \\
\hline & & wet_area & $-0.03 \pm 0.06$ & -0.56 & 0.31 & 0.578 & -- & -- & -- & -- \\
\hline
\end{tabular}




\begin{tabular}{|c|c|c|c|c|c|c|c|c|c|c|}
\hline & $\begin{array}{l}\text { Habitat and AG juxtaposition } \\
10 \mathrm{~km}\end{array}$ & cover $^{2}$ & $-0.05 \pm 0.03$ & -1.6 & 2.56 & 0.112 & 6 & 0.52 & 0.07 & 0.03 \\
\hline & & ag_ji_10km & $0.09 \pm 0.07$ & 1.41 & 1.99 & 0.161 & -- & -- & -- & -- \\
\hline & & wet_area & $-0.02 \pm 0.06$ & -0.3 & 0.09 & 0.762 & -- & -- & -- & -- \\
\hline & $\mathrm{AG}$ area $10 \mathrm{~km}$ & ag_area10km & $-0.10 \pm 0.06$ & -1.65 & 2.71 & 0.102 & 5 & 0.77 & 0.06 & 0.02 \\
\hline & & wet_area & $-0.02 \pm 0.06$ & -0.41 & 0.17 & 0.685 & -- & -- & -- & -- \\
\hline & AG juxtaposition $10 \mathrm{~km}$ & ag_ji_10km & $0.10 \pm 0.06$ & 1.57 & 2.48 & 0.118 & 5 & 0.87 & 0.06 & 0.02 \\
\hline & & wet_area & $0.0002 \pm 0.06$ & 0 & 0 & 0.998 & -- & -- & -- & -- \\
\hline & Null model & wet_area & $-0.01 \pm 0.06$ & -0.23 & 0.05 & 0.816 & 4 & 1.13 & 0.05 & -- \\
\hline & Habitat and WRP area $3.5 \mathrm{~km}$ & cover $^{2}$ & $-0.05 \pm 0.03$ & -1.76 & 3.09 & 0.081 & 6 & 1.24 & 0.05 & 0.03 \\
\hline & & wrp_area $3 \mathrm{~km}$ & $-0.08 \pm 0.07$ & -1.1 & 1.21 & 0.273 & -- & -- & -- & -- \\
\hline & & wet_area & $-0.01 \pm 0.06$ & -0.15 & 0.02 & 0.88 & -- & -- & -- & -- \\
\hline & WRP area $10 \mathrm{~km}$ & wrp_area10km & $-0.10 \pm 0.07$ & -1.39 & 1.94 & 0.166 & 5 & 1.36 & 0.05 & 0.01 \\
\hline & & wet_area & $0.01 \pm 0.06$ & 0.12 & 0.01 & 0.903 & -- & -- & -- & -- \\
\hline & $\begin{array}{l}\text { Habitat and WRP juxtaposition } \\
10 \mathrm{~km}\end{array}$ & $\operatorname{cover}^{2}$ & $-0.05 \pm 0.03$ & -1.72 & 2.96 & 0.088 & 6 & 1.96 & 0.04 & 0.02 \\
\hline & & wrp_ji_10km & $0.05 \pm 0.07$ & 0.71 & 0.5 & 0.48 & -- & -- & -- & -- \\
\hline & & wet_area & $-0.02 \pm 0.06$ & -0.37 & 0.14 & 0.71 & -- & -- & -- & -- \\
\hline
\end{tabular}

${ }^{a}$ Null model contains wet_area as a covariate. Models $(n=41)$ are described in Table 3.4, acronyms are described in Table 3.2 ${ }^{\mathrm{b}} \Delta \mathrm{AIC}_{c}=\mathrm{AIC}_{c} i-\mathrm{AIC}_{c}$ min. Min. for abundance = 614.65; Min. for richness = -73.31. 
Figure 3.1. Model averaged parameter estimates and associated $95 \%$ confidence intervals for the parameters included in best approximating models according to Akaike's Information Criterion $\left(\mathrm{AIC}_{\mathrm{c}}\right)$ and $\Delta \mathrm{AIC}_{\mathrm{c}}$ that examined $(\mathrm{A})$ shorebird abundance and (B) shorebird species richness at seasonal wetlands ( $n=9$ wetlands) in the Mississippi valley of Arkansas and Missouri, August-September 2011.

Parameter acronyms are described in Table 3.1.

A)

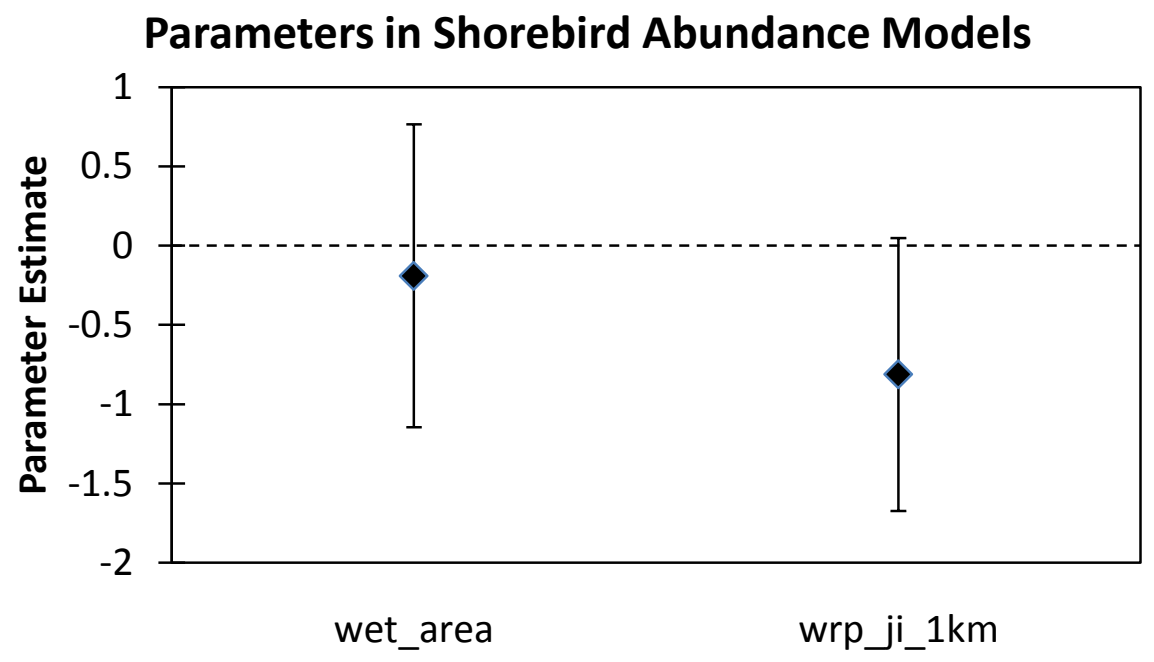

B)

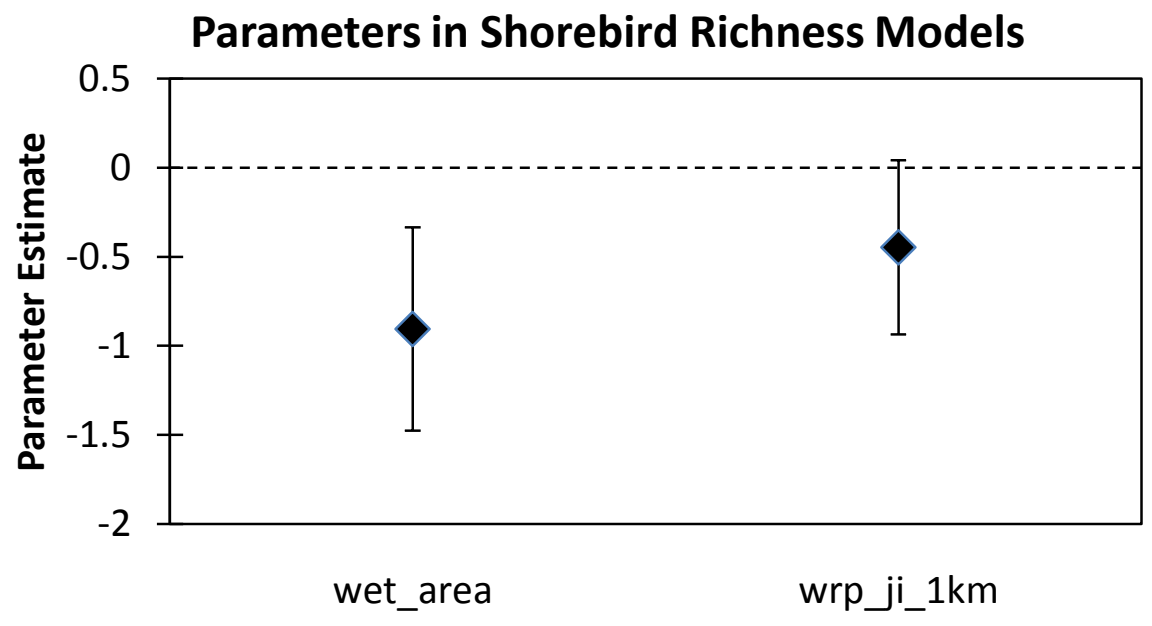


Figure 3.2. Model averaged parameter estimates and associated $95 \%$ confidence intervals for the parameters included in best approximating models according to Akaike's Information Criterion $\left(\mathrm{AIC}_{\mathrm{c}}\right)$ and $\Delta \mathrm{AIC}_{\mathrm{c}}$ that examined (a) dabbling duck abundance and (b) dabbling duck species richness at seasonal wetlands ( $n=18$ wetlands) in the Mississippi valley of Arkansas and Missouri, November 2011-February 2012. Parameter acronyms are described in Table 3.2.

A)

Parameters in Dabbling Duck Abundance Models

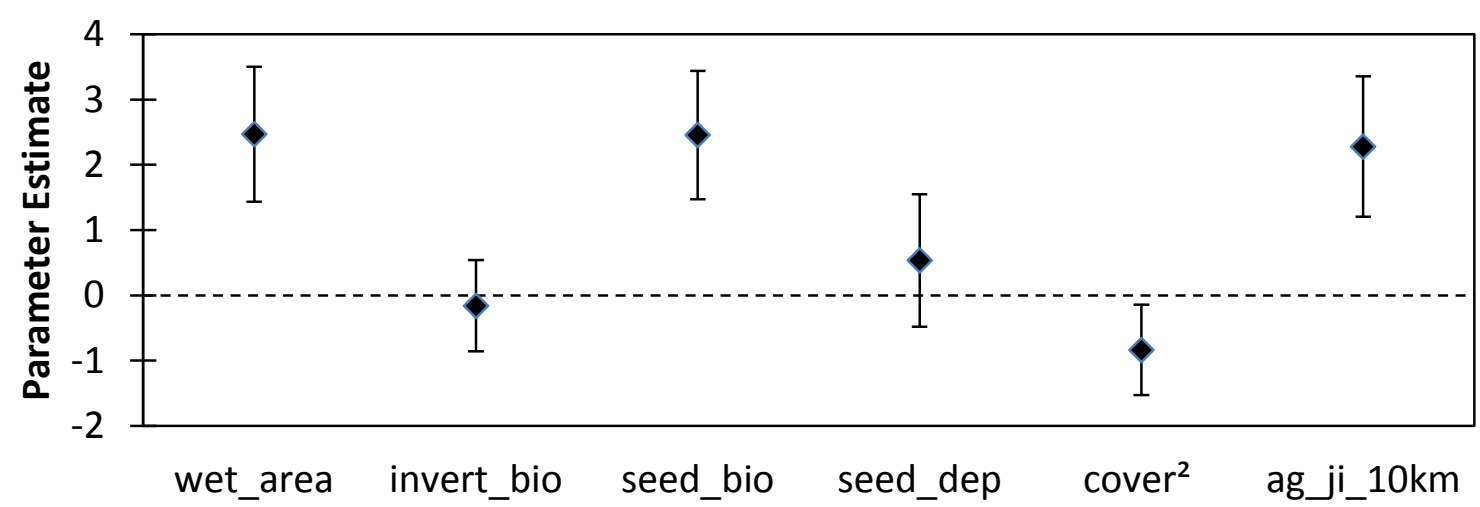

B)

\section{Parameters in Dabbling Duck Richness Models}

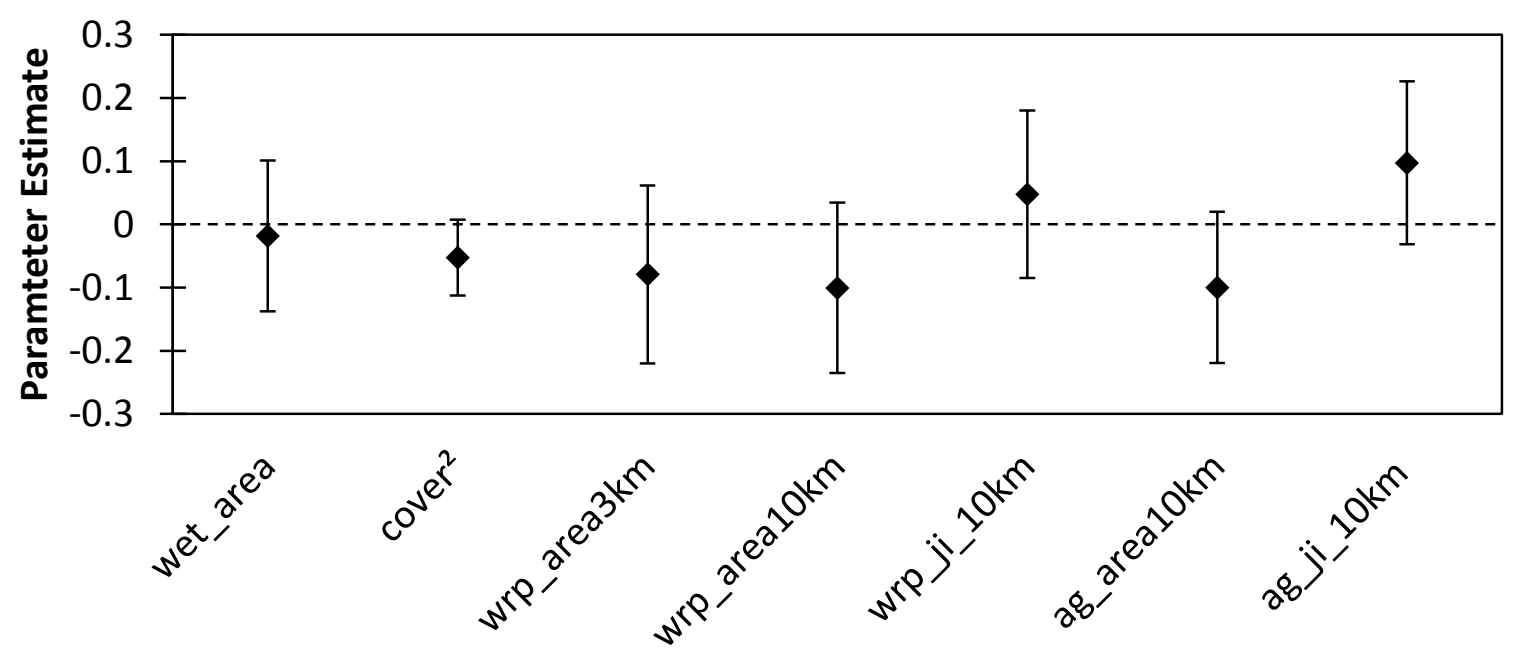




\section{CHAPTER IV:}

\section{EXECUTIVE SUMMARY}

One of the primary areas containing habitat for migrating and wintering waterbirds in the U.S. is located in the Lower Mississippi Alluvial Valley (LMAV). Shallowly inundated, seasonally flooded wetlands are an important habitat type for migratory waterbirds due to specific foraging behaviors and morphological characteristics (Helmers 1992, Colwell and Taft 2000, Isola et al. 2000, Collazo et al. 2002, Webb et al. 2010). Historically, annual flooding of seasonal wetlands was driven by winter and spring precipitation, resulting in favorable habitat conditions for the lifecycles of aquatic invertebrates and germination of moist-soil seeds, and thus providing food for migrating and wintering waterbirds (Heitmeyer and Fredrickson 1981). While the frequency and duration of historic flooding events varied, a large portion of the LMAV was likely inundated every winter (Heitmeyer and Fredrickson 1981). Today, the watersheds throughout the Mississippi valley are dominated and fragmented by agriculture and otherwise developed lands, preventing the natural occurrence and inundation of seasonal wetlands in the landscape (Reinecke et al. 1989, Fredrickson 2005).

The Natural Resource Conservation Service implemented the Migratory Bird Habitat Initiative (MBHI) in summer 2010 to mitigate potential loss of wetland habitat caused by the Deepwater Horizon oil spill (NRCS 2013a). The goal of the MBHI was to improve wetland habitats on private farmlands, catfish ponds, and Wetland Reserve Program (WRP) easements in the Lower Mississippi Alluvial Valley (LMAV) to provide 
additional habitats for wintering and migrating waterbirds. Providing additional assistance to improve habitat on WRP easements was particularly important, considering landowners were not required by contract to provide additional management after initial enrollment/restoration efforts, which in some cases, can increase foods and create habitat conditions (i.e., moderate vegetation cover) that are favorable for waterfowl (EvansPeters et al. 2012, NRCS 2013a, Olmstead et al. 2013). Priorities for WRP wetlands enrolled in the MBHI included increasing waterbird foods and providing habitat structure. Though WRP wetlands have been designated as critical wildlife habitat (King and Keeland 1999, King et al. 2006), little research has been conducted to evaluate WRP management or to quantify its effect on wildlife use and habitat in the LMAV (Fleming et al. 2012, Olmstead et al. 2013). My main objectives were to evaluate factors influencing waterbird density and species richness by making relative comparisons between MBHI wetlands and reference wetlands with differing management activities, food biomass and production, and surrounding landscape.

I conducted waterbird surveys and collected seed and invertebrate samples on WRP wetlands enrolled in MBHI (13 wetlands), WRP wetlands not enrolled in MBHI (12 wetlands), and intensively managed publicly owned wetlands (7 wetlands) in the LMAV of Arkansas and Missouri to quantify food availability and habitat use from August-September 2011 and November 2011-February 2012 by fall migrating shorebirds (Charadriiformes) and wintering dabbling ducks (Anatinae). Additionally, I obtained information from landowners on recent management activities (during the past year), as well as the year each wetland was enrolled in the WRP. Specific management activities characterized included mowing/disking, active inundation, planting, hunting, as well as 
time since WRP enrollment (also referred to as "site age"; 0-10 years or 10-20 years). I also quantified habitat surrounding each study wetland in terms of proximity to, percent area of and interspersion juxtaposition indices of WRP easements within selected buffers. Spatial scales were based the distance shorebirds (1.5km; Albanese et al. 2012) and dabbling ducks $(3.5 \mathrm{~km}$ and 10km; Fredrickson and Reid 1988, Beatty et al. In review) fly between wetlands within stopover or wintering areas.

In Chapter I, I determined that shorebird densities were influenced by percent vegetative cover, with greater densities at sites with lower percent cover. Shorebird densities during autumn were also greater at sites with shorter vegetation height, with most shorebirds using wetlands containing mean vegetation height $<30 \mathrm{~cm}$. Drought conditions combined with landowner reluctance to flood sites until winter resulted in approximately $50 \%$ of study wetlands being completely dry during almost the entire shorebird survey period. Dabbling duck densities at MBHI wetlands were 2.1 times greater than at WRP wetlands; but did not differ from densities at public wetlands. Regardless of wetland type, dabbling duck densities were approximately 2.6 times greater at private wetlands (MBHI and WRP) that were actively inundated compared to sites that were not inundated. Additionally, wetlands that were planted with moist-soil seeds had dabbling duck densities 1.8 times greater than sites where moist-soil seeds were not planted. However, dabbling duck densities were influenced by percent vegetative cover, with the greatest densities occurring at sites with approximately 50\% cover. Dabbling duck densities were 1.8 times greater at wetlands with hunting activities, compared to sites with no hunting activity. Inability to survey all sites at times when waterbirds were 
most likely to be present may have confounded my ability to detect a relationship between food availability and waterbird use metrics.

In Chapter II, I estimated the effects of wetland type (WRP, MBHI, or public), management activities, and sampling technique (core sample vs. sweep sample) on invertebrate biomass, secondary production, and familial richness. During autumn, invertebrate biomass estimates from core samples were over 4 times greater than sweep sample biomass estimates. Conversely, sweep sample familial richness was $50 \%$ greater than core sample estimates. Invertebrate biomass was not affected by mowing, active inundation, and site age. Sweep production estimates were also $60 \%$ greater than benthic core production estimates, regardless of wetland type. Wetland invertebrate studies should consider objectives carefully when determining sampling methods. Failure to sample both nektonic and benthic invertebrates in moist-soil wetlands may cause studies to underestimate common aquatic invertebrate metrics. Additionally, I tested for an effect of sampling frequency on invertebrate biomass during winter and found no difference between monthly and bi-weekly sampling therefore sampling frequency may be reduced. Also, collecting a greater number of samples per wetland may help reduce the variability of invertebrate metrics by accounting for patchy distributions of invertebrates within wetlands (Downing 1991). Invertebrate production at wetlands that were mowed was approximately 4 times greater compared to wetlands that were not mowed. Mowing of vegetation has been proven to increase detritus in moist-soil wetlands and may be an important tool for providing food for invertebrates (Gray et al. 1999, Anderson and Smith 2000, Kostecke et al. 2005). During winter, invertebrate production at WRP and MBHI wetlands were greater than production at public wetlands, 
however, invertebrate production did not differ between WRP and MBHI wetlands. Drought conditions on private lands may have increased decomposition and productivity of aquatic plants, also increasing detritus for invertebrates during winter.

In Chapter I and II, I found that management activities improved seed biomass and invertebrate production, but did not adequately explain variation in waterbird densities; therefore in Chapter III, I created a set of theoretical models to test the hypothesis that a combination of landscape and local variables will explain a greater amount of variability in bird use (abundance and species richness) than landscape or local predictors alone. The best approximating models for both shorebird abundance and species richness contained only wetland area (null models) and juxtaposition of WRP within $1.5 \mathrm{~km}$ of study wetlands. Model estimates indicate that while wetland area was not an important predictor of abundance, it may have been an important predictor of shorebird species richness. Additionally, juxtaposition of WRP was not an important predictor of either shorebird responses. Drought conditions may have caused my estimates of WRP area and proximity to be poor indicators of actual habitat availability across the landscape, and reduced sample size may have impeded my ability to detect an influence of WRP juxtaposition.

Dabbling duck abundance was best predicted by a single model that included all local variables (invertebrate and seed metrics and percent vegetation cover) and cropland juxtaposition within 10km. According to model estimates, dabbling ducks were using seasonal wetlands that contained greater wetland area and moderate vegetative cover. Many studies have documented that vegetation structure is a key factor influencing waterbird use of wetlands because of its' influence on food availability, foraging 
activities, and ability to provide cover (Weller and Spatcher 1965, Murkin et al. 1982, Davis and Smith 1998, Gray et al. 1999, Fairbairn and Dinsmore 2001, Smith et al. 2004, Davis and Bidwell 2008, Webb et al. 2010). Wetlands with greater dabbling duck abundances also had greater abundant local wetland foods (at least moist-soil seeds) with several agricultural fields nearby, indicating a reliance on natural and anthropogenic food sources. However, invertebrate biomass may be a poor predictor of habitat use by all dabbling ducks due to differences in protein requirements between individual birds (Miller 1987, Heitmeyer 1988, Reinecke et al. 1989, Richardson and Kaminski 1992, Anderson et al. 2000). Furthermore, diet studies indicate that mallards (Anas platyrhynchos) probably don't seek out invertebrates during most of the winter (Gruenhagen and Fredrickson 1990, Combs and Fredrickson 1996). There were ten models that were best fit as predictors of dabbling duck species richness, including the null model. These models contained the variables percent cover, cropland area within $10 \mathrm{~km}, \mathrm{WRP}$ area within $10 \mathrm{~km}$, and cropland juxtaposition within 10km, and were not important predictors of species richness.

The exceedingly unpredictable availability of and food resources within individual wetlands implies a need to focus on providing habitat at a broader scale (Skagen et al. 2008, Albanese et al. 2012, Twedt 2013). Ideally, stopover and wintering sites should contain a variety of wetland types with varying management plans, providing habitat for different species of waterbirds as they are present within the region, regardless of seasonal precipitation. The conservation of wetland complexes outside of public lands is an important step toward insuring sufficient stopover and wintering resources are consistently present within a changing landscape such as the LMAV. Reliable sources of 
water are critical for shorebirds, especially during dry years where late drawdowns rates are accelerated by high rates of evapotranspiration. Semi-permanent wetlands, which remain inundated for a few years at a time, and other wetlands that are capable of retaining water in dry summers may be an important habitat to promote for shorebirds. However, summer drought conditions can be beneficial for aquatic invertebrates, which become a more important dietary component for dabbling ducks in the late-winter and spring (Tidwell et al 2013). Dry soils actually increase food sources for invertebrates by allowing plants to establish robust root systems and organic matter to completely dry which speeds up decomposition when inundated (Kadlec 1962, Mitsch and Gosselink 2007, Anderson and Smith 2000, Davis and Bidwell 2008). In agriculture-dominated landscapes such as the LMAV, conservation programs that promote winter flooding of croplands adjacent to important wetland habitats may be an efficient method of providing additional habitats for dabbling ducks. Management at broader spatial scales will require substantial private landowner support and a fundamental understanding of how individual wetlands are incorporated into complexes to provide habitat for all migratory waterbirds.

For decades, wetland managers have been encouraged to include landscape variables when developing plans for habitat management. Fredrickson and Reid (1988) suggested that public land managers should consider all wetlands within a 10-mile radius as the wetland complex when estimating total resources for waterfowl. In some states, private land coordinators use wetland distribution in the surrounding landscape to help rank potential conservation sites, such as Wetland Reserve Program (WRP) enrollments. Successful enrollments receive financial and technical assistance for restoration and management activities (NRCS 2013b). On Arkansas, up to $19 \%$ of the ranking to 
establish which lands are enrolled in the WRP is determined by proximity to conservation areas and contiguous forest (King et al. 2006). Private land coordinators in Missouri use a wetland habitat appraisal guide (WHAG), which scores WRP applicants on land use types such as nonforested wetland and cropland within 2 miles of each potential easement (Kevin Dacey, personal communication, January 25, 2012). My results support that landscape composition should be considered as an important component in the ranking of potential WRP easements in the LMAV.

This study was designed to evaluate the effects of MBHI on waterbird and assess the importance of wetland management activities on conservation easement lands. Despite spring flooding events and summer drought conditions, I found that management activities at WRP easements have the potential to increase seed biomass and invertebrate production, and create habitat conditions similar to long-term publicly managed wetlands within a relatively short time frame. In addition, private wetlands attracted greater mean dabbling duck densities than public reference sites during winter 2011-2012. Among management activities, active inundation had the greatest impact on dabbling duck densities, followed by moist-soil seed planting and mowing. There were no patterns of shorebird use among study wetlands, however, probably due to autumn drought conditions. The most important management activities for waterbirds on private lands are likely those that ensure habitat availability (i.e. actively flooding wetlands), and those that ensure wetland habitats are accessible to waterbirds (i.e. manipulation of vegetation structure). 


\section{LITERATURE CITED}

Albanese, G., C. A. Davis, and B. W. Compton. 2012. Spatiotemporal scaling of North American continental interior wetlands: implications for shorebird conservation. Landscape Ecology 27:1465-1479.

Anderson, J. T. and L. M. Smith. 2000. Invertebrate response to moist-soil management of playa wetlands. Ecological Applications 10:550-558.

Anderson, J. T., L. M. Smith, and D. A. Haukos. 2000. Food selection and feather molt by nonbreeding American green-winged teal in Texas playas. The Journal of Wildlife Management 64:222-230.

Beatty, W. S., E. B. Webb, D. C. Kesler, A. H. Raedeke, L. W. Naylor, and D. D. Humburg. Landscape effects on waterbird habitat selection at multiple scales during the non-breeding season. In review.

Collazo, J. A., D. A. O'Harra, and C. A. Kelly. 2002. Accessible habitat for shorebirds: Factors influencing its availability and conservation implications. Waterbirds 25:13-24.

Colwell, M. A. and O. W. Taft. 2000. Waterbird communities in managed wetlands of varying water depth. Waterbirds 23:45-55.

Combs, D. L. and L. H. Fredrickson. 1996. Foods used by male mallards wintering in southeastern Missouri. The Journal of Wildlife Management 60:603-610.

Davis, C. A. and J. R. Bidwell. 2008. Response of aquatic invertebrates to vegetation management and agriculture. Wetlands 28:793-805.

Davis, C. A. and L. M. Smith. 1998. Ecology and management of migrant shorebirds in the Playa Lakes Region of Texas. Wildlife Monographs 140:1-45.

Downing, J. A. 1991. The effect of habitat structure on the spatial distribution of freshwater invertebrate populations. Pages 87-106 in S. S. Bell, E. D. McCoy, and H. R. Mushinsky, editors. Habitat structure. Springer Netherlands.

Evans-Peters, G. R., B. D. Dugger, and M. J. Petrie. 2012. Plant Community Composition and Waterfowl Food Production on Wetland Reserve Program Easements Compared to Those on Managed Public Lands in Western Oregon and Washington. Wetlands 32:391-399.

Fairbairn, S. E. and J. J. Dinsmore. 2001. Local and landscape-level influences on wetland bird communities of the prairie pothole region of Iowa, USA. Wetlands 21:41-47. 
Fleming, K. S., R. M. Kaminski, T. E. Tietjen, M. L. Schummer, G. N. Ervin, and K. D. Nelms. 2012. Vegetative Forage Quality and Moist-soil Management on Wetlands Reserve Program Lands in Mississippi. Wetlands 32:919-929.

Fredrickson, L. H. 2005. Greentree reservoir management: implications of historic practices and contemporary considerations to maintain habitat values." Ecology and management of bottomland hardwood systems: the state of our understanding. Special Publication 10:479-486.

Fredrickson, L. H. and F. A. Reid. 1988. "Waterfowl Use of Wetland Complexes." in U. S. F. a. W. S. U.S. Department of the Interior, editor. Waterfowl Management Handbook, Fort Collins, Colorado.

Gray, M. J., R. M. Kaminski, G. Weerakkody, B. D. Leopold, and K. C. Jensen. 1999. Aquatic invertebrate and plant responses following mechanical manipulations of moist-soil habitat. Wildlife Society Bulletin 27:770-779.

Gruenhagen, N. M. and L. H. Fredrickson. 1990. Food use by migratory female mallards in Northwest Missouri. The Journal of Wildlife Management 54:622-626.

Heitmeyer, M. E. and L. H. Fredrickson. 1981. Do wetland conditions in the Mississippi Delta hardwoods influence Mallard recruitment. Pages 44-57 in North American Wildlife and Natural Resources Conference.

Helmers, D. L. 1992. Shorebird management manual. Western Hemisphere Shorebird Reserve Network, Manomet, Massachusetts.

Isola, C., M. Colwell, O. Taft, and R. Safran. 2000. Interspecific differences in habitat use of shorebirds and waterfowl foraging in managed wetlands of California's San Joaquin Valley. Waterbirds 23:196-203.

Kadlec, J. A. 1962. Effects of a drawdown on a waterfowl impoundment. Ecology 43:267-281.

King, S. L. and B. D. Keeland. 1999. Evaluation of reforestation in the lower Mississippi River alluvial valley. Restoration Ecology 7:348-359.

King, S. L., D. J. Twedt, and R. R. Wilson. 2006. The role of the Wetland Reserve Program in conservation efforts in the Mississippi Alluvial Valley. The Wildlife Society Bulletin 34:914-920.

Kostecke, R. M., L. M. Smith, and H. M. Hands. 2005. Macroinvertebrate response to cattail management at Cheyenne Bottoms, Kansas, USA. . Wetlands 25:758-763.

Miller, M. R. 1987. Fall and winter foods of northern pintails in the Sacramento Valley, California. The Journal of Wildlife Management 51:405-414. 
Mitsch, W. J. and J. G. Gosselink. 2007. Wetlands. Fourth Edition. John Wiley and Sons, Inc, Hoboken, New Jersey, USA.

Murkin, H. R., R. M. Kaminski, and R. D. Titman. 1982. Responses by dabbling ducks and aquatic invertebrates to an experimentally manipulated cattail marsh. Canadian Journal of Zoology 60:2324-2332.

Natural Resources Conservation Service. 2013a. Migratory Bird Habitat Initiative. https://prod.nrcs.usda.gov/wps/portal/nrcs/detailfull/national/programs/farmbill/in itiatives/?cid=steldevb1027669/ Accessed 2013 June 27.

Natural Resources Conservation Service. 2013b. Wetlands Reserve Program. http://www.nrcs.usda.gov/wps/portal/nrcs/main/national/programs/easements/wetl ands/ Accessed 2013 June 27.

Olmstead, V. G., E. B. Webb, and R. W. Johnson. 2013. Moist-Soil Seed Biomass and Species Richness on Wetland Reserve Program Easements in the Mississippi Alluvial Valley. Wetlands 33:1-10.

Reinecke, K. J., R. C. Barkley, and C. K. Baxter. 1988. Potential effects of changing water conditions on mallards wintering in the Mississippi Alluvial Valley. Pages 325-337 in M. W. Weller, editor. Waterfowl in winter. University of Minnesota Press, Minneapolis, USA.

Reinecke, K. J., R. M. Kaminski, D. J. Moorehead, J. D. Hodges, and J. R. Nassar. 1989. Mississippi Alluvial Valley. Pages 203-247 in L. M. Smith, R. L. Pederson, and R. M. Kaminski, editors. Habitat management for migrating and wintering waterfowl in North America. Texas Tech University Press, Lubbock, USA.

Richardson, D. M. and R. M. Kaminski. 1992. Diet restriction, diet quality, and prebasic molt in female mallards. The Journal of Wildlife Management 56:531-539.

Skagen, S. K., D. A. Granfors, and C. P. Melcher. 2008. On determining the significance of ephemeral continental wetlands to North American migratory shorebirds. Auk 125:20-29.

Smith, L. M., D. A. Haukos, and R. M. Prather. 2004. Avian response to vegetative pattern in playa wetlands during winter. Wildlife Society Bulletin 32:474-480.

Tidwell, P. R., E. B. Webb, M. P. Vrtiska, and A. A. Bishop. 2013. Diets and Food Selection of Female Mallards and Blue-Winged Teal During Spring Migration. Journal of Fish and Wildlife Management 4:63-74.

Twedt, D. J. 2013. Foraging Habitat for Shorebirds in Southeastern Missouri and its Predicted Future Availability. Wetlands 33:1-12. 
Webb, E. B., L. M. Smith, M. P. Vrtiska, and T. G. Lagrange. 2010a. Effects of local and landscape variables on wetland bird habitat use during migration through the Rainwater Basin. The Journal of Wildlife Management 74:109-119.

Webb, E. B., L. M. Smith, M. P. Vrtiska, and T. G. Lagrange. 2010b. Community structure of wetland birds during spring migration through the rainwater basin. The Journal of Wildlife Management 74:765-777.

Weller, M. W. and C. S. Spatcher. 1965. Role of habitat in the distribution and abundance of marsh birds. Agricultural and Home Economic Experiment Station, Iowa State University of Science and Technology, Ames, Iowa, USA. 


\section{APPENDIX A}

Mean density (birds/ha) and frequency of occurrence (proportion of surveys in which that species was observed) of each waterbird species observed during biweekly surveys at Wetland Reserve Program (WRP) wetlands, Migratory Bird Habitat Initiative (MBHI) wetlands, and publicly owned (PUBLIC) wetlands in the Lower Mississippi Alluvial Valley of Arkansas and Missouri, 3 August -16 September 2011.

\begin{tabular}{|c|c|c|c|c|c|c|c|c|c|c|}
\hline \multirow{2}{*}{ SPECIES } & & \multicolumn{3}{|c|}{ WRP $(n=12)$} & \multicolumn{3}{|c|}{ MBHI $(n=12)$} & \multicolumn{3}{|c|}{ PUBLIC $(n=6)$} \\
\hline & & $\bar{x}$ & SE & $\%$ Occ & $\bar{x}$ & SE & $\%$ Occ & $\bar{x}$ & SE & $\%$ Occ \\
\hline \multicolumn{11}{|l|}{ Charadriiformes } \\
\hline Spotted sandpiper & Actitis macularius & 0.00 & 0.00 & 0.00 & 0.09 & 0.09 & 4.35 & 0.00 & 0.00 & 0.00 \\
\hline Baird's sandpiper & Calidris bairdii & 0.11 & 0.11 & 6.67 & 0.09 & 0.09 & 4.35 & 0.00 & 0.00 & 0.00 \\
\hline Pectoral sandpiper & Calidris melanotos & 0.02 & 0.02 & 6.67 & 0.10 & 0.10 & 4.35 & 0.00 & 0.00 & 0.00 \\
\hline Least sandpiper & Calidris minutilla & 2.67 & 2.24 & 26.67 & 0.80 & 0.59 & 13.04 & 0.00 & 0.00 & 0.00 \\
\hline Semipalmated sandpiper & Calidris pusilla & 0.72 & 0.43 & 26.67 & 0.00 & 0.00 & 0.00 & 0.18 & 0.18 & 9.09 \\
\hline Killdeer & $\begin{array}{l}\text { Charadrius } \\
\text { vociferous }\end{array}$ & 2.21 & 0.99 & 40.00 & 5.81 & 1.86 & 69.57 & 3.58 & 1.76 & 45.45 \\
\hline Wilson's snipe & Gallinago delicata & 0.19 & 0.19 & $<0.01$ & 0.09 & 0.06 & 0.00 & $<0.01$ & $<0.01$ & 9.09 \\
\hline Black-necked stilt & $\begin{array}{l}\text { Himantopus } \\
\text { mexicanus }\end{array}$ & 1.16 & 0.59 & 26.67 & 0.18 & 0.18 & 4.35 & 0.00 & 0.00 & 0.00 \\
\hline Short-billed dowitcher & $\begin{array}{l}\text { Limnodromus } \\
\text { griseus }\end{array}$ & 0.00 & 0.00 & 0.00 & $<0.01$ & $<0.01$ & 4.35 & 0.00 & 0.00 & 0.00 \\
\hline Long-billed dowitcher & $\begin{array}{l}\text { Limnodromus } \\
\text { scolopaceus }\end{array}$ & $<0.01$ & $<0.01$ & 6.67 & 0.10 & 0.10 & 13.04 & 0.00 & 0.00 & 0.00 \\
\hline Lesser yellowlegs & Tringa flavipes & 0.00 & 0.00 & 0.00 & 0.10 & 0.10 & 4.35 & 0.00 & 0.00 & 0.00 \\
\hline Greater yellowlegs & Tringa melanoleuca & 0.26 & 0.19 & 20.00 & 0.08 & 0.07 & 8.70 & 6.08 & 6.08 & 9.09 \\
\hline $\begin{array}{l}\text { Solitary sandpiper } \\
\text { Gruiiformes }\end{array}$ & Tringa solitaria & 0.01 & 0.01 & 6.67 & 0.66 & 0.29 & 21.74 & 0.10 & 0.10 & 9.09 \\
\hline American coot & Fulica americana & 0.00 & 0.00 & 0.00 & 0.00 & 0.00 & 0.00 & 0.01 & 0.01 & 9.09 \\
\hline
\end{tabular}




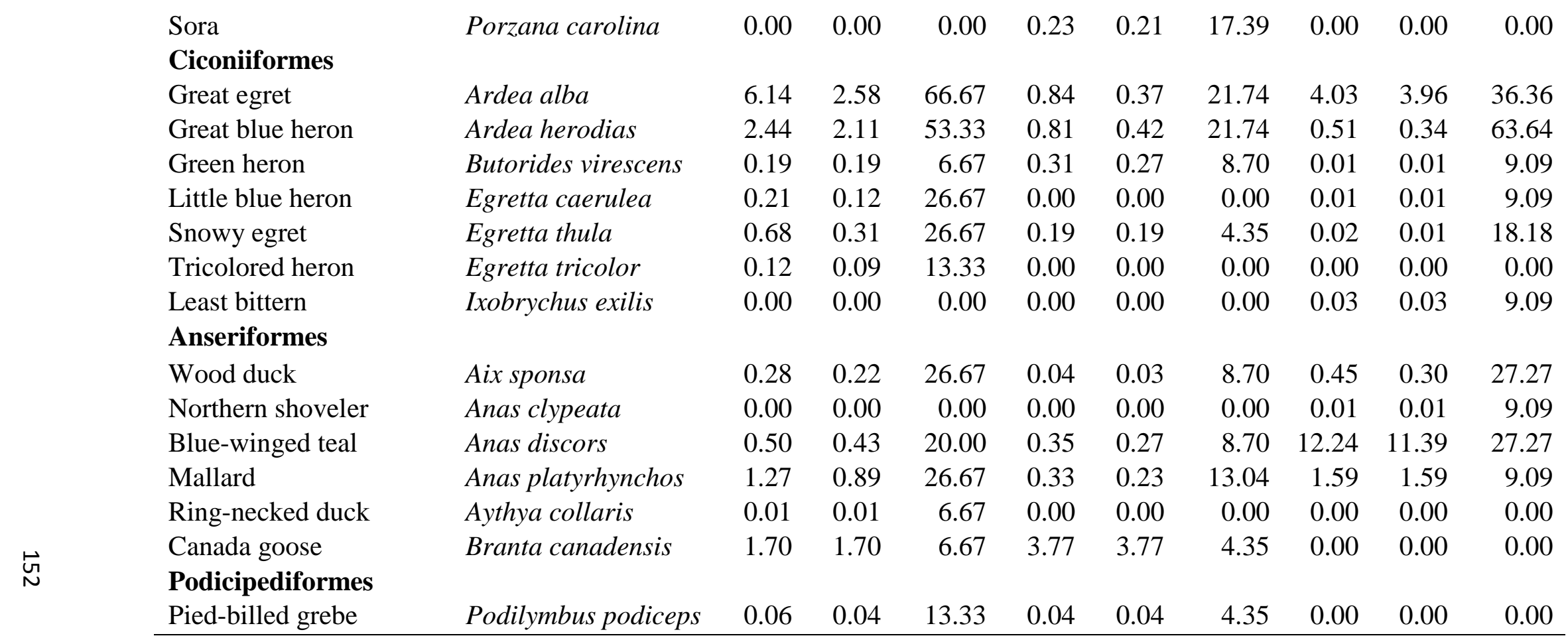




\section{APPENDIX B}

Mean density (birds/ha) and frequency of occurrence (proportion of surveys in which that species was observed) of waterfowl (Anseriformes) species observed during biweekly surveys at Wetland Reserve Program (WRP) wetlands, Migratory Bird Habitat Initiative (MBHI) wetlands, and publicly owned (PUBLIC) wetlands in the Lower Mississippi Alluvial Valley of Arkansas and Missouri, 3 November 2011-24 February 2012.

\begin{tabular}{|c|c|c|c|c|c|c|c|c|c|c|}
\hline \multirow{2}{*}{ SPECIES } & & \multicolumn{3}{|c|}{ WRP $(n=12)$} & \multicolumn{3}{|c|}{ MBHI $(n=13)$} & \multicolumn{3}{|c|}{ PUBLIC $(n=7)$} \\
\hline & & Mean & SE & $\%$ Occ & Mean & SE & $\%$ Occ & Mean & SE & $\%$ Occ \\
\hline \multicolumn{11}{|l|}{ Anatinae } \\
\hline Wood duck & Aix sponsa & 0.11 & 0.06 & 6.73 & 0.09 & 0.08 & 2.80 & 0.00 & 0.00 & 0.00 \\
\hline Northern pintail & Anas acuta & 0.03 & 0.02 & 3.85 & 0.15 & 0.10 & 6.54 & 1.18 & 0.64 & 15.63 \\
\hline American Wigeon & Anas americana & 0.00 & 0.00 & 0.00 & 0.04 & 0.04 & 1.87 & 0.02 & 0.01 & 4.69 \\
\hline Green-winged teal & Anas crecca & 0.72 & 0.42 & 18.27 & 1.22 & 0.50 & 16.82 & 0.85 & 0.46 & 21.88 \\
\hline Northern shoveler & Anas clypeata & 0.76 & 0.24 & 20.19 & 4.31 & 1.79 & 31.78 & 2.46 & 1.00 & 29.69 \\
\hline Blue-winged teal & Anas discors & 0.24 & 0.19 & 2.88 & 0.10 & 0.06 & 4.67 & 0.00 & 0.00 & 0.00 \\
\hline Mallard & Anas platyrhynchos & 3.05 & 0.66 & 42.31 & 11.85 & 3.14 & 57.01 & 21.34 & 6.52 & 53.13 \\
\hline Gadwall & Anas strepera & 0.46 & 0.12 & 21.15 & 5.96 & 2.31 & 32.71 & 0.54 & 0.25 & 25.00 \\
\hline \multicolumn{11}{|l|}{ Aythyinae } \\
\hline Lesser scaup & Aythya affinis & 0.00 & 0.00 & 0.00 & $<0.01$ & $<0.01$ & 0.93 & 0.00 & 0.00 & 0.00 \\
\hline Redhead & Aythya americana & 0.00 & 0.00 & 0.00 & 0.03 & 0.03 & 2.80 & 0.03 & 0.03 & 1.56 \\
\hline Ring-necked duck & Aythya collaris & 0.85 & 0.30 & 17.31 & 3.88 & 1.69 & 21.50 & 2.34 & 1.10 & 18.75 \\
\hline Canvasback & Aythya valisineria & 0.00 & 0.00 & 0.00 & 0.00 & 0.00 & 0.00 & 0.10 & 0.10 & 1.56 \\
\hline Bufflehead & $\begin{array}{l}\text { Bucephala albeola } \\
\text { Lophodytes }\end{array}$ & 0.00 & 0.00 & 0.00 & $<0.01$ & $<0.01$ & 2.80 & 0.00 & 0.00 & 0.00 \\
\hline Hooded merganser & cucullatus & 0.05 & 0.02 & 14.42 & 0.19 & 0.10 & 10.28 & 0.07 & 0.05 & 4.69 \\
\hline Ruddy duck & Oxyura jamaicensis & 0.01 & 0.01 & 0.96 & 0.02 & 0.02 & 0.93 & 0.10 & 0.07 & 4.69 \\
\hline \multicolumn{11}{|l|}{ Anserinae } \\
\hline Greater white-fronted goose & Anser albifrons & 0.00 & 0.00 & 0.00 & 0.00 & 0.00 & 0.00 & 0.02 & 0.01 & 4.69 \\
\hline
\end{tabular}




\begin{tabular}{|c|c|c|c|c|c|c|c|c|c|c|}
\hline Canada goose & Branta canadensis & 0.00 & 0.00 & 0.00 & $<0.01$ & $<0.01$ & 0.93 & 0.86 & 0.48 & 15.63 \\
\hline Cackling goose & Branta hutchinsii & 0.00 & 0.00 & 0.00 & 0.00 & 0.00 & 0.00 & 0.08 & 0.07 & 4.69 \\
\hline Snow goose & Chen caerulescens & 0.00 & 0.00 & 0.00 & 0.00 & 0.00 & 0.00 & 0.00 & 0.00 & 0.00 \\
\hline Tundra swan & Cygnus columbianus & 0.00 & 0.00 & 0.00 & 0.00 & 0.00 & 0.00 & 0.01 & 0.01 & 3.13 \\
\hline
\end{tabular}




\section{APPENDIX C}

Mean dry mass ( $\mathrm{kg} / \mathrm{ha})$ of all invertebrate taxa observed in biweekly samples collected at

Migratory Bird Habitat Initiative wetlands ( $n=6)$, Wetland Reserve Program

wetlands $(n=6)$, and publicly owned wetlands $(n=7)$ in Arkansas and Missouri

during autumn 2011 and winter 2012.

\begin{tabular}{|c|c|c|c|c|c|c|c|}
\hline \multirow[b]{2}{*}{ Orders } & \multirow[b]{2}{*}{ Families } & \multicolumn{2}{|c|}{ Winter } & \multicolumn{4}{|c|}{ Autumn } \\
\hline & & $\begin{array}{c}\text { Sweep } \\
\bar{x}\end{array}$ & SE & $\begin{array}{c}\text { Sweep } \\
\bar{x}\end{array}$ & SE & $\begin{array}{c}\text { Core } \\
\bar{x}\end{array}$ & SE \\
\hline Amphipoda & Gammaridae & 0.0587 & 0.0073 & $<0.0001$ & $<0.0001$ & $<0.0001$ & $<0.0001$ \\
\hline Anostraca & Branchinectidae & 0.0021 & 0.0009 & - & - & - & \\
\hline Aranae & Spiders & 0.0371 & 0.0143 & 0.0059 & 0.0043 & 0.0124 & 0.0124 \\
\hline Chilopoda & Chilopoda & 0.0001 & 0.0001 & - & - & - & \\
\hline Cladocera & Daphniidae & 0.2145 & 0.0163 & $<0.0001$ & $<0.0001$ & $<0.0001$ & $<0.0001$ \\
\hline \multirow{14}{*}{ Coleoptera } & Belostomatidae & 0.0520 & 0.0253 & 0.0047 & 0.0047 & 75.4004 & 75.4004 \\
\hline & Carabidae & 0.0028 & 0.0010 & 0.0038 & 0.0038 & 0.6956 & 0.6956 \\
\hline & Chrysomelidae & 0.0393 & 0.0230 & 0.0033 & 0.0031 & 0.1118 & 0.0998 \\
\hline & Coccinellidae & 0.0003 & 0.0003 & - & 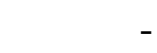 & - & \\
\hline & Curculionidae & 0.0066 & 0.0018 & 0.0004 & 0.0004 & $<0.0001$ & $<0.0001$ \\
\hline & Dytiscidae & 0.1823 & 0.0565 & 0.3893 & 0.2321 & 1.4285 & 1.4285 \\
\hline & Elmidae & 0.0070 & 0.0053 & - & - & - & \\
\hline & Georsyssidae & 0.0007 & 0.0007 & - & - & - & \\
\hline & Gyrinidae & 0.0264 & 0.0148 & $<0.0001$ & $<0.0001$ & 0.1242 & 0.1242 \\
\hline & Haliplidae & 0.0338 & 0.0113 & 0.0542 & 0.0302 & $<0.0001$ & $<0.0001$ \\
\hline & Hydrophilidae & 0.1015 & 0.0281 & 0.0828 & 0.0251 & 0.1863 & 0.0954 \\
\hline & Salpingidae & 0.0022 & 0.0020 & - & - & - & \\
\hline & Scirtidae & 0.0001 & 0.0001 & - & - & - & \\
\hline & Staphylinidae & $<0.0001$ & $<0.0001$ & - & - & - & \\
\hline Copepoda & Copepoda & 0.0645 & 0.0057 & 0.0007 & 0.0007 & 0.0124 & 0.0124 \\
\hline \multirow[t]{2}{*}{ Decapoda } & Cambaridae & 0.6575 & 0.2714 & $<0.0001$ & $<0.0001$ & $<0.0001$ & $<0.0001$ \\
\hline & Palaemonidae & 0.1756 & 0.0532 & 0.3358 & 0.1906 & $<0.0001$ & $<0.0001$ \\
\hline \multirow[t]{9}{*}{ Diptera } & Ceratopogonidae & 0.0024 & 0.0007 & 0.0015 & 0.0009 & & \\
\hline & Chironomidae & 0.2204 & 0.0679 & 0.1026 & 0.0429 & 0.3727 & 0.1233 \\
\hline & Culicidae & 0.0126 & 0.0054 & 0.0020 & 0.0012 & $<0.0001$ & $<0.0001$ \\
\hline & Dixidae & $<0.0001$ & $<0.0001$ & - & - & - & \\
\hline & Dolichopodidae & $<0.0001$ & $<0.0001$ & - & - & $<0.0001$ & $<0.0001$ \\
\hline & Ephydridae & $<0.0001$ & $<0.0001$ & - & - & - & \\
\hline & Sarcophagidae & 0.0011 & 0.0011 & - & - & - & \\
\hline & Tabanidae & 0.0199 & 0.0086 & - & - & - & \\
\hline & Tipulidae & 0.0009 & 0.0006 & - & - & - & \\
\hline Entomobryomorpha & Isotomidae & 0.0174 & 0.0052 & 0.0005 & 0.0005 & 0.0248 & 0.0173 \\
\hline
\end{tabular}




\begin{tabular}{|c|c|c|c|c|c|c|c|}
\hline \multirow[t]{4}{*}{ Ephemeroptera } & Baetidae & 0.0172 & 0.0040 & 0.0018 & 0.0012 & $<0.0001$ & $<0.0001$ \\
\hline & Caenidae & 0.0251 & 0.0075 & 0.0107 & 0.0076 & - & - \\
\hline & Metretopodidae & 0.0003 & 0.0003 & - & - & - & - \\
\hline & Siphlonuridae & 0.0002 & 0.0002 & - & - & - & - \\
\hline \multirow[t]{2}{*}{ Gastropoda } & Physidae & 0.3607 & 0.0705 & 0.6660 & 0.3000 & 6.5711 & 5.2805 \\
\hline & Planorbidae & 0.8162 & 0.3116 & 9.7449 & 5.4070 & 60.4943 & 60.4943 \\
\hline Haplotaxida & Naididae & 0.1924 & 0.1558 & 0.0007 & 0.0007 & 0.2360 & 0.2360 \\
\hline \multirow[t]{14}{*}{ Hemiptera } & Aphididae & 0.0002 & 0.0001 & - & - & - & - \\
\hline & Cicadellidae & 0.0039 & 0.0017 & 0.0035 & 0.0021 & 0.0124 & 0.0124 \\
\hline & Coreidae & 0.0002 & 0.0002 & - & - & - & - \\
\hline & Corixidae & 0.1416 & 0.0197 & 3.2777 & 1.2823 & 4.8321 & 2.3295 \\
\hline & Gelastocoridae & 0.0012 & 0.0011 & - & - & - & - \\
\hline & Gerridae & 0.0001 & 0.0001 & - & - & - & - \\
\hline & Hebridae & 0.0032 & 0.0023 & 0.0025 & 0.0022 & 0.0621 & 0.0621 \\
\hline & Hydrometridae & 0.0001 & 0.0001 & - & - & - & - \\
\hline & Membracidae & 0.0017 & 0.0015 & - & - & - & - \\
\hline & Mesoveliidae & 0.0032 & 0.0019 & 0.0015 & 0.0011 & - & - \\
\hline & Nepidae & 0.0029 & 0.0029 & - & - & - & - \\
\hline & Notonectidae & 0.0071 & 0.0050 & $<0.0001$ & $<0.0001$ & $<0.0001$ & $<0.0001$ \\
\hline & Saldidae & 0.0041 & 0.0012 & 0.0005 & 0.0004 & 0.0248 & 0.0248 \\
\hline & Veliidae & 0.0015 & 0.0010 & 0.0002 & 0.0002 & - & - \\
\hline Hympenoptera & Formicidae & 0.0017 & 0.0007 & - & - & 0.1242 & 0.0867 \\
\hline \multirow[t]{2}{*}{ Isopoda } & Asellidae & 0.2427 & 0.0329 & 0.0006 & 0.0006 & - & - \\
\hline & Ixodidae & $<0.0001$ & $<0.0001$ & 0.0013 & 0.0013 & - & - \\
\hline \multirow[t]{3}{*}{ Lepidoptera } & Cosmopterigidae & 0.0005 & 0.0003 & - & - & - & - \\
\hline & Cossidae & 0.0184 & 0.0094 & - & - & - & - \\
\hline & Pyralidae & 0.0073 & 0.0045 & - & - & 0.2484 & 0.2244 \\
\hline Lumbriculida & Lumbriculidae & 0.0194 & 0.0032 & 0.0090 & 0.0029 & 5.1923 & 2.1351 \\
\hline \multirow[t]{8}{*}{ Odonata } & Aeshnidae & 0.0019 & 0.0011 & 0.0067 & 0.0040 & 0.2236 & 0.2112 \\
\hline & Coenagrionidae & 0.0071 & 0.0016 & 0.0222 & 0.0149 & $<0.0001$ & $<0.0001$ \\
\hline & Corduliidae & 0.0042 & 0.0036 & $<0.0001$ & $<0.0001$ & $<0.0001$ & $<0.0001$ \\
\hline & Gomphidae & 0.0033 & 0.0033 & $<0.0001$ & $<0.0001$ & $<0.0001$ & $<0.0001$ \\
\hline & Lestidae & 0.0004 & 0.0002 & - & - & - & - \\
\hline & Libellulidae & 0.0037 & 0.0020 & 0.0102 & 0.0102 & - & - \\
\hline & Petaluridae & 0.0046 & 0.0023 & $<0.0001$ & $<0.0001$ & $<0.0001$ & $<0.0001$ \\
\hline & Zygoptera & 0.0002 & 0.0001 & - & - & - & - \\
\hline Orthoptera & Gryllidae & 0.0005 & 0.0005 & - & - & - & - \\
\hline Plecoptera & Plecoptera & 0.0002 & 0.0002 & - & - & - & - \\
\hline Poduroidea & Poduridae & $<0.0001$ & $<0.0001$ & - & - & - & - \\
\hline Symphypleona & Sminthuridae & 0.0001 & 0.0001 & - & - & - & - \\
\hline Thysanoptera & Phlaeothripidae & 0.0003 & 0.0003 & - & - & - & - \\
\hline \multirow[t]{2}{*}{ Trichoptera } & Limnephilidae & 0.0006 & 0.0005 & - & - & - & - \\
\hline & Rhyacophilidae & $<0.0001$ & $<0.0001$ & - & - & - & - \\
\hline Veneroida & & 0.0004 & 0.0018 & - & - & 0.0248 & 0.0248 \\
\hline (Subclass) Hirudinea & & 0.0001 & 0.0001 & - & - & 6.0122 & 4.5580 \\
\hline
\end{tabular}

